\title{
"O que não está nos autos, não está no mundo...": a diversidade da interpretação da verdade formal no controle do reexame de provas em recursos especiais pelo Superior Tribunal de Justiça
}

Hercilio Luiz Tavares Junior ${ }^{1}$

\begin{abstract}
[...] O verdadeiro problema não é estudar como a vida humana se submete às regras - ela simplesmente não se submete -, o verdadeiro problema é saber como as regras se adaptaram à vida. (Malinowski, 2008, p. 95)
\end{abstract}

\section{Resumo}

O presente trabalho procura estabelecer uma relação entre o princípio da verdade formal e os fundamentos a que recorre o Superior Tribunal de Justiça - STJ no exame de cabimento dos recursos especiais, a partir do Enunciado n.$^{\circ} 7$ da sua Súmula, com ênfase nos casos em que se reconhece ser inaplicável aquele enunciado. $\mathrm{O}$ ponto de partida foi a identificação dos elementos comuns entre a análise do juízo a quo, na instância recursal ordinária, e a realizada pelo STJ, quanto aos fatos, provas e circunstâncias nos processos judiciais objeto de recurso especial. A metodologia de pesquisa enfatizou a base epistemológica na chamada "reviravolta lingüística" da filosofia ou "giro lingüístico" - como superação da metafísica, do solipsismo e da separação rígida entre sujeito e objeto de pesquisa, especialmente os "giros" ontológico, hermenêutico e pragmático. As técnicas de pesquisa utilizadas tiveram em vista a apresentação dos resultados da pesquisa preliminar; a análise da jurisprudência do STJ com base na noção de postulados normativos; e uma apresentação dos resultados o mais didática possível. Como resultado, espera-se demonstrar que o controle dos recursos especiais pelo STJ pode ser analisado com base no conceito de Standards, a partir de uma análise textual de acórdãos da jurisprudência do tribunal. Espera-se, desse modo, contribuir para o aprimoramento

\footnotetext{
Monografia apresentada em 2009, como requisito para a obtenção do título de bacharel em Direito pelo Centro Universitário de Brasília. Orientador: Prof. Dilnei Giseli Lorenzi. Monografia vencedora do Concurso de Monografias “Victor Nunes Leal” do Núcleo de Pesquisa e Monografia do Uniceub (2009).
} 
da discussão a respeito da relação do princípio da verdade formal com as formas de controle do livre convencimento motivado do julgador na jurisprudência do STJ.

Palavras-chave: Processo civil. Prova. Reexame. Valoração. Sentença. Recurso especial. Jurisprudência. Súmula. Princípios. Postulados normativos. Oralidade. Verdade formal. Livre convencimento. Interpretação. Discurso jurídico. Ideologia. Discurso competente. Atos de fala. Agir comunicativo. Paradoxo. Círculo hermenêutico. Espiral hermenêutica. Giro lingüístico. Semiótica. Senso comum. Controle e standards.

\section{Introdução}

O tema da monografia resumido na frase: "O QUE NÃO ESTÁ NOS AUTOS, NÃO ESTÁ NO MUNDO...”, é uma tradução aproximada do brocardo jurídico latino QUOD NON EST IN ACTIS NON EST IN MUNDO, e a sua delimitação foi assim definida: "a diversidade da interpretação da verdade formal no controle do reexame de provas em recursos especiais pelo Superior Tribunal de Justiça”.

O brocardo jurídico que fundamenta o tema da monografia representa a idéia que, na formação do livre convencimento motivado do julgador em relação à verdade da causa, os autos da ação judicial são a fonte de onde o julgador extrai a sua convicção. Essa concepção, ligada ao modo de agir do juiz de primeiro grau, está presente na doutrina do processo, no Código de Processo Civil e também na jurisprudência dos tribunais.

A motivação para a escolha do referido tema, surgiu com a leitura de algumas passagens de textos de autoria do filósofo alemão Jürgen Habermas, à época da elaboração do projeto de pesquisa em monografia, oportunidade em que foram constatadas três dificuldades no estudo do referido autor:

- o amplo acervo bibliográfico produzido por Habermas;

- a diversidade dos temas abordados e dos interlocutores em debate; e - as mudanças do seu itinerário intelectual, nas temáticas investigadas. 
Nesse particular, a orientação recebida durante a elaboração da redação final da monografia, viabilizou um exame cuidadoso dos rótulos a respeito da obra de Habermas, de modo a evitar sua classificação irrefletida, em relação às diversas correntes filosóficas.

A outra motivação da pesquisa se relaciona com a relevância atual do tema, pois a investigação sobre decisões fundamentadas em jurisprudência sumulada ganhou uma maior repercussão, a partir da promulgação da Emenda Constitucional n. ${ }^{\circ} 45 / 2004$, no debate a respeito das súmulas vinculantes e o seu papel na liberdade de decisão dos julgadores.Além disso, a preocupação sobre a excessiva carga processual e as formas de filtragem dos recursos na instância extraordinária (Supremo Tribunal Federal - STF e Superior Tribunal de Justiça - STJ), que existia à época da proposta de divisão, entre ambos, da competência então reservada ao STF (exame dos aspectos constitucional e infraconstitucional), na chamada "Crise do STF”, nos anos 80, ainda persiste, não apenas em relação ao STF, mas agora abrangendo também o trabalho do STJ.

Quanto aos estudos precedentes sobre o tema, a multiplicidade dos aspectos envolvidos demandou uma pesquisa preliminar de amplitude maior do que inicialmente fora previsto. Fato que obrigou a uma divisão do objeto de estudo entre a análise da doutrina jurídica e a pesquisa sobre os paradigmas em filosofia. Logo, na seleção da bibliografia foi priorizada a temática da análise da linguagem jurídica e sua relação com a pretensão do direito à autonomia, neutralidade e universalização.

A partir desses referenciais teóricos, priorizando a natureza interdisciplinar do direito, foi estabelecido o ponto de partida de investigação, no fato que o Superior Tribunal de Justiça - STJ, seguindo a tradição do Supremo Tribunal Federal nos recursos extraordinários, não reconhece o cabimento de recursos especiais, quando a matéria da interposição é relacionada ao conteúdo fático-probatório.

Fundamenta o STJ essa decisão em uma evidência de natureza doutrinária, a qual existiria entre as questões de fato e as questões de direito, interpretando o âmbito de sua competência constitucional, apenas em relação ao segundo aspecto. 
E, ao mesmo tempo, de forma paradoxal, o STJ procede ao reexame de fatos e provas, em situações especiais, utilizando como argumento para a prática dessa excepcionalidade, o conceito de valoração da prova. Pela noção de valoração da prova, em contraposição ao reexame, o STJ estaria adotando uma prática de auto-regulação de decisões, baseando-se unicamente na sua jurisprudência, fundamentado em precedentes.

Em vista disso, a concepção de hermenêutica jurídica subjacente ao trabalho, consistiria em considerar o processo de interpretação, como uma atividade alográfica, concepção na qual o trabalho hermenêutico não teria o objetivo de perscrutar o sentido "correto" dado, por vontade do legislador, (A) verdade da norma, e sim, que o intérprete acrescenta à compreensão do texto, elementos criativos resultantes de seu modo de ver e da sua experiência pessoal no mundo.

Quanto ao objetivo geral da monografia, consiste em verificar o discurso de justificação das práticas de reexame e valoração da prova no exame de cabimento dos recursos especiais pelo Superior Tribunal de Justiça - STJ, na aplicação do Enunciado n. ${ }^{\circ} 7$ da sua Súmula, e as conseqüências em relação ao princípio da verdade formal. Em função desses requisitos definidos para a pesquisa, o trabalho foi dividido em três capítulos, os quais foram estruturados em tópicos de investigação, conforme a temática apresentada a seguir.

No Capítulo Primeiro - o dilema entre fatos e direito no recurso especial - procura-se identificar a aplicação do princípio da verdade formal nos recursos especiais; as situações concretas do convencimento judicial; e o seu controle por meio de standards; o argumento da distinção entre questões de fato e de direito; a justificativa da supressão de instância; os precedentes judiciais; o prequestionamento como processo de filtragem dos recursos; e a característica do efeito devolutivo nos recursos especiais.

No Capítulo Segundo - uma visão interdisciplinar do discurso jurídico - o estudo da teoria processual sobre os princípios jurídicos da oralidade, livre convencimento motivado, persuasão racional, verdade formal e verdade real; na metodologia de trabalho, a aplicação dos conceitos de ideologia, senso comum teórico, 
fetichização do discurso jurídico, círculo hermenêutico, ruptura epistemológica e a situação ideal de fala na teoria da ação comunicativa; e por último, as técnicas de pesquisa da jurisprudência do Superior Tribunal de Justiça e da análise de conteúdo das decisões judiciais examinadas.

E, no Capítulo Terceiro - a valoração da prova e a verdade formal - a aplicação dos conceitos do Capítulo 2, escolhidos a partir dos casos concretos do Capítulo 1, para a análise de outros julgados do STJ, de natureza diferente dos recursos especiais (medidas cautelares, ações rescisórias e mandados de segurança).

Com a abordagem de um tema com inúmeras possibilidades de interpretação, não se pretende, por óbvio, esgotar sua análise ou apresentar soluções aos problemas identificados. Contudo, espera-se que sirva ao aperfeiçoamento pessoal do aluno e, até mesmo, chamar a atenção para o assunto ou o seu aprofundamento pelos interessados.

\section{0 dilema entre fatos e direito no recurso especial}

A atuação do Superior Tribunal de Justiça - STJ - no exame de cabimento dos recursos especiais (RESP) - quando trata da vedação do reexame de fatos e provas, não deve ser compreendida de forma isolada do contexto em que esse órgão se acha instalado e dos fundamentos legais de sua criação e atuação como órgão jurisdicional, tendo em vista a Constituição Federal, a legislação ordinária a seu respeito e os seus regulamentos.

Com o intuito de verificar as principais circunstâncias que viabilizam a prática adotada pelo tribunal, em relação à descoberta da verdade processual nos recursos especiais, torna-se oportuno o exame do STJ sob o ponto de vista de sua estrutura organizacional e das suas competências e atribuições.

O Superior Tribunal de Justiça - STJ tem sua missão definida nos arts. 104 e 105 da Constituição Federal de 1988, com a redação da Emenda Constitucional de $n$. $^{\circ} 45$, de 8 de dezembro de 2004, sendo composto por, no mínimo, 33 (trinta 
e três) ministros, nomeados pelo Presidente da República, entre brasileiros com mais de trinta e cinco anos e menos de sessenta e cinco, de notável saber jurídico e reputação ilibada, após aprovação por maioria absoluta do Senado Federal. ${ }^{2}$

Os membros do STJ, segundo as regras constitucionais, são nomeados entre os ocupantes de carreiras relacionadas com a prestação jurisdicional e, em cada terço das vagas existentes, são escolhidos da seguinte forma: entre: juízes dos Tribunais Regionais Federais; juízes dos Tribunais de Justiça; e, no último terço, alternadamente, entre advogados e membros do Ministério Público. ${ }^{3}$

As competências do STJ, previstas nos incisos de I a III do art. 105 da Constituição, são divididas, segundo sua natureza, originária ou recursal e, em relação as primeiras, cabe ao STJ, no inciso I do art. 105 da Constituição Federal, em defesa dos direitos fundamentais, processar e julgar:

- crimes comuns e de responsabilidade envolvendo autoridades públicas;

- mandados de segurança, habeas corpus, habeas data e mandados de injunção, exceto do poder judiciário, se envolvida autoridade federal;

- os conflitos de competência, entre tribunais, tribunais e juízes, ou entre juízes, não vinculados entre si;

- os conflitos de atribuições entre autoridades da União, entre estados ou entre a União e estados;

- a reclamação, ação rescisória e revisões criminais dos seus julgados; e

- a homologação de sentenças estrangeiras e o exequatur a cartas rogatórias. ${ }^{4}$

No inciso II do art. 105 da Constituição Federal encontra-se definida a competência do STJ para julgar, em sede de recurso ordinário, em única ou última

2 PRESIDÊNCIA DA REPÚBLICA. CONSTITUIÇÃO DA REPÚBLICA FEDERATIVA DO BRASIL. Disponível em: https://legislacao.planalto.gov.br. Acesso em: 15 out. 2008.

3 Ibidem.

4 MORAES, Alexandre de. Direito constitucional. 14 ed. São Paulo: Atlas, 2003. p. 475476. 
instância, as decisões denegatórias de habeas corpus e mandados de segurança dos tribunais regionais federais e tribunais dos estados e do Distrito Federal. ${ }^{5}$

No inciso III, a previsão para o STJ julgar os recursos especiais e, no Parágrafo único do mesmo artigo, a menção ao funcionamento, junto àquela Corte, da Escola Nacional de Formação e Aperfeiçoamento da Magistratura e do Conselho da Justiça Federal. ${ }^{6}$

Na parte que interessa diretamente ao trabalho, em relação ao inciso III do caput do art. 105 da Constituição Federal, nas alíneas "a", "b" e "c", tratando sobre os recursos especiais, encontra-se estabelecido que ao STJ são cometidas as seguintes competências, transcritas na forma a seguir, in verbis:

Art. 105. Compete ao Superior Tribunal de Justiça:

$[\ldots]$

III - julgar, em recurso especial, as causas decididas, em única ou última instância, pelos Tribunais Regionais Federais ou pelos tribunais dos Estados, do Distrito Federal e Territórios, quando a decisão recorrida:

a) contrariar tratado ou lei federal ou negar-lhes vigência;

b) julgar válido ato de governo local contestado em face de lei federal;

c) der a lei federal interpretação divergente da que lhe haja atribuído outro tribunal. ${ }^{7}$

Conforme visto do texto da Constituição acima, cabe ao STJ julgar recursos especiais no controle da interpretação das leis e tratados de âmbito federal, desde que sejam em única ou a última instância; que haja resistência ou contrariedade à norma legal; ou que haja mais de uma interpretação em relação à mesma.

Ibidem. p. 477.

6 Ibidem. p. 463.

7 PRESIDÊNCIA DA REPÚBLICA. Disponível em: https://legislacao.planalto.gov.br. Acesso em: 15 out. 2008. 
Quanto à legislação ordinária a respeito do Superior Tribunal de Justiça - STJ é oportuna a referência aos dispositivos apresentados na tabela a seguir, relacionados com a atividade do Tribunal, embora não sejam objeto de análise no presente trabalho. Há ainda outras leis que fazem referência ao STJ, porém não tratam precipuamente de normas processuais ou cujo assunto é matéria penal, administrativa ou orçamentária. ${ }^{8}$

QUADRO 1 - LEGISLAÇÃO ORDINÁRIA SOBRE O SUPERIOR TRIBUNAL DE JUSTIÇA

\begin{tabular}{|c|c|c|}
\hline $\begin{array}{c}\text { LEI } \\
11.672 / 2008\end{array}$ & $08 / 05 / 2008$ & $\begin{array}{l}\text { ACRESCE O ART. 543-C À LEI N }{ }^{\circ} \text { 5.869, DE } 11 \text { DE } \\
\text { JANEIRO DE } 1973 \text { - CÓDIGO DE PROCESSO CIVIL, } \\
\text { ESTABELECENDO O PROCEDIMENTO PARA O } \\
\text { JULGAMENTO DE RECURSOS REPETITIVOS NO } \\
\text { ÂMBITO DO SUPERIOR TRIBUNAL DE JUSTIÇA. }\end{array}$ \\
\hline $\begin{array}{c}\text { LEI } \\
11.636 / 2007\end{array}$ & $28 / 12 / 2007$ & $\begin{array}{l}\text { DISPÕE SOBRE AS CUSTAS JUDICIAIS DEVIDAS } \\
\text { NO ÂMBITO DO SUPERIOR TRIBUNAL DE } \\
\text { JUSTIÇA. }\end{array}$ \\
\hline $\begin{array}{c}\text { LEI } \\
8.038 / 1990\end{array}$ & $28 / 05 / 1990$ & $\begin{array}{l}\text { INSTITUI NORMAS PROCEDIMENTAIS PARA } \\
\text { OS PROCESSOS QUE ESPECIFICA, PERANTE } \\
\text { O SUPERIOR TRIBUNAL DE JUSTIÇA E O } \\
\text { SUPREMO TRIBUNAL FEDERAL. }\end{array}$ \\
\hline
\end{tabular}

Fonte: Base da Legislação Federal. ${ }^{9}$

Em relação às normas acima referidas a que provavelmente teria maior repercussão em relação ao presente trabalho seria a Lei n. ${ }^{\circ} \mathbf{1 1 . 6 7 2 / 2 0 0 8}$, que trata da filtragem de recursos na instância ordinária, impedindo a subida ao STJ de recursos cuja questão central de direito já tenha sido decidida pelo tribunal.

Ocorre que a fundamentação para essa filtragem, provavelmente, demandaria a discussão de pontos que serão abordados no presente trabalho, tais como a diferenciação entre questões de fato e de direito e as implicações dessa diferenciação no reconhecimento do papel do tribunal como instância de cassação ou de revisão.

8 Ibidem.

9 PRESIDÊNCIA DA REPÚBLICA. Disponível em: https://legislacao.planalto.gov.br. Acesso em: 15 out. 2008. 
Além disso, sendo recente a edição dessa lei, não há um acervo substancial de posicionamentos doutrinários a respeito, os quais permitissem uma melhor fundamentação do ponto de vista teórico, evitando-se desse modo uma análise precipitada a respeito.

Por outro lado, além das competências atribuídas pela Constituição Federal e das leis ordinárias sobre aspectos específicos do seu desempenho institucional, o STJ tem competência para aprovar regulamentos complementares, a respeito de questões práticas do dia-a-dia do tribunal. Desde modo, o STJ aprovou seu Regimento Interno, no qual se acham detalhados os procedimentos em relação aos recursos especiais.

Nota-se que o exame criterioso do Regimento Interno do STJ, pela sua dimensão e detalhamento, demandaria uma pesquisa a parte, o que não se ajuste aos objetivos pretendidos neste trabalho. Não obstante essa dificuldade, a análise do regimento interno do STJ terá como objetivo principal identificar os aspectos considerados de maior relevância ao estudo pretendido, com ênfase na definição da estrutura de atuação do tribunal.

O Regimento interno do STJ demarca a sua forma de atuação especialmente quanto aos seguintes aspectos: o tribunal enquanto instituição; as atribuições dos ministros, individual e coletivamente; e a forma como acontece a comunicação jurisdicional. ${ }^{10}$

Quanto à atuação do tribunal, o seu Regimento Interno estabelece a distribuída das suas atribuições, na Parte I, Título I, nos Capítulos I e II (arts. $1^{\circ}$ a 16), e nos Capítulos de VIII a XIII (art. 38 a 60); na Parte II, Título I (art. 66 a 138) e no Título XI (art. 289 a 300); na Parte III, Títulos I a III (art. 316 a 327), estando revogado o Título IV (art. 328 a 331); e a Parte IV, Títulos I e II (art. 332 a 344).

${ }^{10}$ SUPERIOR TRIBUNAL DE JUSTIÇA. Disponível em: http://www.stj.jus.br/SCON/ regimento/. Acesso em: 15 out. 2008. 
Nos dispositivos do seu Regimento Interno o STJ regulamenta a especialização em áreas, o funcionamento do plenário, corte especial, sessões e turmas e o conselho de administração. Trata das comissões e do Conselho da Justiça Federal e define regras sobre licenças, substituições, convocações e a eleição de representantes na Justiça Eleitoral. Aposentadorias, a polícia do tribunal e a representações disciplinares.

Além disso, estabelece normas sobre registro e classificação de feitos, distribuição, prazos processuais e as correspondentes despesas, a assistência judiciária e o modo da elaboração da sua jurisprudência, além de orientar sobre a forma de prestação dos seus serviços administrativos.

Quanto aos seus ministros, o Regimento Interno do STJ estabelece, na Parte I, Título I, nos Capítulos de III a VII, a representação do tribunal (Presidente, Vice-presidente e Corregedor-Geral da Justiça Federal) e, na prestação jurisdicional, as atribuições do Presidente das turma e seções e o papel dos relatores (causas em geral) ou revisores (área penal). E no Título II, a forma de atuação dos membros do Ministério Público (art. 61 a 65).

Em relação à forma de comunicação o STJ regulamenta a atuação dos sujeitos e partes processuais, na forma falada (audiências), na Parte II, Título IV (art. 105 e 106), e textual (escrita): as provas, na Parte II, Título II (art. 139 a 147); a organização das sessões dos diversos órgãos, no Título III (art. 148 a 184); e na forma de análise dos diversos tipos de processo, nos Títulos V a VIII e X (art. 187 a 288), aí incluídos os recursos, no Título IX (art. 244 a 270) e as diversas formas de execução, no Título XII (art. 301 a 315).

Para os fins da presente pesquisa, importa estabelecer, em linhas gerais, a prioridade dada à comunicação no tribunal, a partir do levantamento temático do seu Regimento Interno: 149 (cento e quarenta e nove) artigos tratam sobre o funcionamento do tribunal; enquanto 21 (vinte e um) dispõem sobre seus ministros; e 162 (cento e sessenta e dois) sobre sujeitos processuais e a atuação das partes.

Quanto às normas regimentais, cabe referência ao art. 34, sobre as atribuições dos relatores, nos incisos I, VII, VIII, XVI e XVIII. 
Art. 34. São atribuições do relator:

I - ordenar e dirigir o processo;

$[\ldots]$

VII - decidir agravo de instrumento interposto de decisão que inadmitir recurso especial;

VIII - requisitar os autos originais, quando necessário;

$[\ldots]$

XVI - determinar a autuação do agravo como recurso especial;

$[\ldots]$

XVIII - negar seguimento a pedido ou recurso manifestamente intempestivo, incabível, improcedente, contrário a súmula do tribunal, ou quando for evidente a incompetência deste. 11

Em relação aos dispositivos acima transcritos, a amplitude de atuação do relator do processo é genérica (inciso I), com natureza plena em relação à decisão de agravo de instrumento contra decisão do tribunal que negue seguimento ao recurso especial (inciso VII), como também para acatar esse recurso e transformá-lo em RESP (inciso XVI).

Por outro lado, a requisição dos autos originais - embora não se defina quando há necessidade - é atribuição importante para o exame de fatos e provas na lide (inciso VIII), o que viabilizaria a referência a toda a fundamentação da causa.

Quanto à competência para negar seguimento a pedido ou recurso (inciso XVIII), a autonomia do relator é plena, não existindo forma de rever essa decisão monocrática, salvo nos casos de expressa violação às normas legais, o que leva a concluir que, não haveria um procedimento de controle da forma de decisão no processo judicial e, além disso, essa competência teria amparo, além das disposições do CPC, na jurisprudência do tribunal, onde o mesmo pode recusar o pedido ou recurso que seja contrário à Súmula do STJ.

${ }^{11}$ SUPERIOR TRIBUNAL DE JUSTIÇA. Disponível em: http://www.stj.jus.br/SCON/ regimento/. Acesso em: 15 out. 2008. 
Em relação à estrutura dos órgãos de julgamento do tribunal, tendo em vista a apreciação do Recurso Especial (RESP), o art. $2^{\circ}$ do Regimento Interno do STJ estabelece a hierarquia do tribunal em Plenário, Corte Especial, Seções e Turmas especializadas. ${ }^{12}$

Quanto à forma de julgamento dos recursos especiais, a competência originária para a sua apreciação cabe às turmas, nos termos do art. 13, inciso IV, do Regimento Interno do STJ, sendo que em relação à revisão de jurisprudência da qual proveio enunciado de súmula, como também nos casos de incidente de uniformização de jurisprudência, é feita a remessa do feito à seção da qual faz parte a turma, conforme previsão nos incisos I e III do art. 14 do Regimento Interno do STJ. ${ }^{13}$

Além disso, em relação às matérias objeto de revisão (inciso II) ou de incidente de uniformização de jurisprudência (inciso III), cabe remessa à Corte Especial, independentemente de acórdão, no caso do inciso III, conforme determina o art. 16 do Regimento Interno do STJ. ${ }^{14}$

Na verdade à Corte Especial do STJ compete de forma geral a matéria atribuída à jurisdição do tribunal, exceto julgar os recursos especiais, sendo relevante destacar as matérias afetas à jurisprudência, conforme disposto no inciso VI do art. 11 do Regimento Interno e inciso VII, no parágrafo único do mesmo artigo, transcritos a seguir. ${ }^{15}$

Art. 11. Compete à Corte Especial processar e julgar:

[...]

VI - os incidentes de uniformização de jurisprudência, em caso de divergência na interpretação do direito entre as seções, ou quando a matéria for comum a mais de uma seção, aprovando a respectiva súmula;

\footnotetext{
${ }^{12}$ SUPERIOR TRIBUNAL DE JUSTIÇA. Disponível em: http://www.stj.jus.br/SCON/ regimento/. Acesso em: 15 out. 2008.

${ }^{13}$ Ibidem.

${ }^{14}$ SUPERIOR TRIBUNAL DE JUSTIÇA. Disponível em: http://www.stj.jus.br/SCON/ regimento/. Acesso em: 15 out. 2008.

${ }^{15}$ Ibidem.
} 


\section{$[\ldots]$}

Parágrafo único - Compete, ainda, à Corte Especial:

$[\ldots]$

VII - sumular a jurisprudência uniforme comum às seções e deliberar sobre a alteração e o cancelamento de suas súmulas;

Quanto à forma de deliberação do mérito em recursos especiais e da sua jurisprudência, o quorum de votação nas turmas é por maioria absoluta, o que vale para o que for decidido em RESP, conforme determina o art. 181 do Regimento Interno do STJ. ${ }^{16}$

Enquanto nas seções a presença mínima para votação - a qual normalmente é por maioria absoluta - no julgamento de incidente de uniformização de jurisprudência - exige-se o quorum mínimo de 2/3 (dois terços), conforme o art. 176 do Regimento Interno. ${ }^{17}$

Já a Corte Especial, cuja presença mínima seria de maioria absoluta dos membros, no julgamento de uniformização da jurisprudência, sumulação e cancelamento ou alteração de enunciado de súmula, entre outras, o quorum mínimo para sua deliberação seria também de $2 / 3$ (dois terços), conforme determina o art. 172 do seu Regimento Interno. ${ }^{18}$

Diante dessas situações, deve ser observado que o papel das turmas é realçado no julgamento do RESP, enquanto que as alterações à jurisprudência do tribunal são dificultadas pela exigência de um quorum maior.

O enunciado ${ }^{\circ} 7$ da Súmula do STJ, de texto "A pretensão de simples reexame de prova não enseja recurso especial., foi aprovado em 28/06/1990, com base no art. 257 do Regimento Interno. Com base nesse artigo, o cabimento ensejaria exame de mérito, não do recurso, mas da causa: “[...] No julgamento do Recurso

\footnotetext{
${ }^{16}$ SUPERIOR TRIBUNAL DE JUSTIÇA. Disponível em: http://www.stj.jus.br/SCON/ regimento/. Acesso em: 15 out. 2008.

${ }^{17}$ Ibidem.

${ }^{18}$ SUPERIOR TRIBUNAL DE JUSTIÇA. Disponível em: http://www.stj.jus.br/SCON/ regimento/. Acesso em: 15 out. 2008.
} 
Especial verificar-se-á, preliminarmente, se o recurso é cabível. Decidida a preliminar pela negativa, a Turma não conhecerá do recurso; se pela afirmativa, julgará a causa, aplicando o direito à espécie.. ${ }^{19}$

Deste modo caberia indagar porque foi editado o enunciado $n .^{\circ} 7$, se a própria orientação do regimento interno do tribunal é no sentido da apresentação do mérito da lide como um todo e não apenas das questões de direito como será visto adiante.

A despeito disso, cabe observar a forma como o STJ justifica a aplicação desse enunciado de súmula, bem como convém perceber quais são os efeitos dessa prática sobre o exame de cabimento dos recursos especiais e sobre a efetividade da prestação jurisdicional pelo STJ.

\subsection{0 argumento da diferença entre direito material e formal}

A pesquisa preliminar na jurisprudência do STJ revelou que um dos argumentos mais utilizados para legitimar a vedação ao reexame de provas, no exame de cabimento dos recursos especiais, tendo por base o enunciado n. ${ }^{\circ} 7$ da Súmula do tribunal, diz respeito a uma hipotética diferença entre questões de fato e questões de direito, onde as primeiras seriam, segundo o STJ, da competência decisória das instâncias recursais ordinárias, enquanto as segundas é que seriam da alçada recursal extraordinária, no caso em questão o RESP, por tratarem de matéria de direito e não de fato.

Como exemplo da argumentação quanto ao exclusivo exame de questões de direito em sede recursal extraordinária, há o Recurso Especial n. ${ }^{\circ}$ 759/GO, Relator Ministro Cláudio Santos, na decisão da 3a Turma, em 07/11/1989, quando ficou decidido que "[...] O exame de cabimento de recurso especial é limitado ao direito aplicado no acórdão recorrido. Não são reexaminadas provas no julgamento dos recursos constitucionais.". ${ }^{20}$

\footnotetext{
${ }^{19}$ Ibidem.

${ }^{20}$ SUPERIOR TRIBUNAL DE JUSTIÇA. Disponível em: http://www.stj.jus.br/SCON/ pesquisar.jsp. Acesso em: 15 out. 2008.
} 
Três aspectos sobressaem na decisão transcrita: o impedimento de reexame de provas em RESP; a idéia que o exame de cabimento do recurso é realizado em relação à legislação envolvida; e que a legislação tenha sido aplicada no acórdão recorrido, daí se extraindo duas condições de cabimento: o prequestionamento e a questão de direito.

Também no Agravo Regimental no Agravo de Instrumento n. ${ }^{0} 7.953 / \mathrm{MG}$, Relator Ministro Barros Monteiro, apreciado pela $4^{\text {a }}$ Turma, em 04/12/1991, a manifestação do STJ foi no sentido de que: “[...] 2. Hipótese em que não se cuida de valoração da prova (o erro de direito quanto ao valor da prova, abstratamente considerado), mas de reexame de matéria probatória, o que é defeso na via do apelo excepcional (Súmula n. ${ }^{\circ} 7$ do STJ)... ${ }^{21}$

Observa-se aí a apresentação de um conceito do que vem a ser a valoração da prova, no erro de direito, estabelecendo como limitação do exame recursal em RESP, acerca do valor hipotético de um determinado tipo de prova, o que ratificaria o discurso do STJ sobre a vedação ao reexame das provas em si. Nessa linha de entendimento o STJ realiza a produção de uma verdade processual, que passa a ser parte do senso comum dos operadores jurídicos envolvidos, como se verá de forma mais detalhada no restante deste trabalho.

Do mesmo modo, no Agravo Regimental no Agravo de Instrumento n. ${ }^{\circ}$ 1.004.828/MG, Relatora Ministra Eliana Calmon, 2a Turma, em 19/08/2008, o STJ manteve seu entendimento quanto à distinção entre direito material e formal, quando reiterou que: “[...] 2. Não há falar em violação da Súmula 7/STJ por esta Corte se a decisão recorrida limitou-se a analisar tese jurídica, sem recorrer ao conjunto fático-probatório dos autos.".22

Segundo essa decisão, o STJ manifesta que qualquer tese jurídica pode ser debatida, desde que não haja novo exame do conteúdo de fatos e provas, o que

\footnotetext{
${ }^{21}$ Ibidem.

22 SUPERIOR TRIBUNAL DE JUSTIÇA. Disponível em: http://www.stj.jus.br/SCON/ pesquisar.jsp. Acesso em: 15 out. 2008.
} 
vem a ser o fundamento do texto do Enunciado n. ${ }^{\circ} 7$ da sua Súmula. Assim, o STJ considera que, havendo questão de direito a apreciar, é cabível o conhecimento e julgamento de recurso especial, o que não seria possível nos pedidos de reexame de mérito do conteúdo fático-probatório.

Diante da importância dada pelo tribunal a essa distinção, induzindo à idéia de que o assunto conta com uma opinião unânime na doutrina jurídica a respeito, cabe uma análise preliminar acerca desse fundamento, a qual pode ser realizada com respeito à natureza da norma jurídica, onde se verifica que há divergências sobre o assunto, sendo possível a identificação de pelo menos duas formas de pensamento a esse respeito. ${ }^{23}$

Haveria uma corrente chamada "unitária", sendo um dos seus formuladores Francesco Carnelutti, que entende existir uma continuidade entre direito material e norma processual, a qual teria função de complementar o direito pleiteado, à vista da natureza imperfeita da lei, levando a efetividade do direito reconhecido na sentença judicial. ${ }^{24}$

Da mesma forma, haveria uma corrente dualista do direito, pela qual a realização do direito material (bem jurídico protegido) dependeria exclusivamente da norma e não da relação processual, a qual teria função de mero cumprimento do direito material, juntamente com a obrigação a ele inerente, anteriores à existência do processo. ${ }^{25}$

${ }^{23}$ CINTRA, Antônio Carlos de Araújo, GRINOVER, Ada Pellegrini, DINAMARCO, Cândido Rangel. Teoria geral do processo. 22. ed. São Paulo: Malheiros, 2006. p. 45.

${ }^{24}$ Segundo esses autores, no trecho referido: "[...] Para outros, como Carnelutti, o direito objetivo não tem condições para disciplinar sempre todos os conflitos de interesses, sendo necessário o processo, muitas vezes, para a complementação dos comandos da lei.." Ibidem. p. 45.

${ }^{25}$ Ainda segundo esses autores, mesmo texto: [...] Para Chiovenda e outros, o ordenamento jurídico cinde-se nitidamente em direito material e direito processual (teoria dualista do ordenamento jurídico): o primeiro dita as regras abstratas e estas se tornam concretas no exato momento em que ocorre o fato enquadrado em suas previsões, automaticamente, sem qualquer participação do juiz. O processo visa apenas à atuação (ou seja, à realização prática) da vontade do direito, não contribuindo em nada para a formação das normas concretas; o direito subjetivo e a obrigação preexistem a ele. Ibidem. p. 45 
Sobre o ponto de vista da existência de uma natureza assemelhada entre o direito material e o formal, parte da doutrina entende ser possível a aplicação das normas do primeiro ao processo, a exemplo da analogia, submetendo-se o direito processual às mesmas disposições do direito material, inclusive a autointegração e heterointegração.

[...] a lei processual é regra jurídica e como tal se subsume ao preceito suprajurídico de que as lacunas deve ser 'autointegradas' ou 'heterointegradas'. [...] na omissão da lei, deve haver o suprimento pela analogia, pelos costumes e pelos princípios gerais de direito. ${ }^{26}$

Como visto, as normas processuais em nada difeririam de outras no direito material, a exemplo da interpretação realizada pelo magistrado, no exercício da jurisdição, onde haveria uma dupla atividade: a aplicação da lei ao caso concreto, com vista à sua finalidade precípua; e a interpretação do seu conteúdo, de modo a fundamentar a decisão da causa, como em qualquer outra área do conhecimento jurídico.

[...] Aplicar a lei é fazê-la incidir no caso concreto, e esse é o dever do magistrado. Diversa é a segunda etapa dessa tarefa, qual seja observar o alcance da norma, a sua razão de ser e a sua finalidade. A essa atividade intelectiva denomina-se de interpretação da lei, que pressupõe a existência da norma jurídica. A hermenêutica processual não difere das demais, posto indicar ao juiz o tempero necessário entre a aplicação da lei sua justiça no caso concreto. ${ }^{27}$

Segundo essa linha de raciocínio, não teria procedência o argumento do STJ sobre uma distinção objetiva quanto à diferença de natureza entre direito material e formal, que justificasse o exame de cabimento dos recursos especiais. Mas não apenas a norma jurídica processual seria idêntica às demais, como também o próprio conceito de fato jurídico, segundo a doutrina do direito civil. Logo não

${ }^{26}$ FUX, Luiz. Curso de direito processual civil. Rio de Janeiro: Forense, 2001. p. 20. (grifo do autor)

${ }^{27}$ FUX, Luiz. Curso de direito processual civil. Rio de Janeiro: Forense, 2001. p. 20. (grifo do autor). 
haveria como separar a espécie norma jurídica da espécie norma de decisão, ambas vinculadas à interpretação e aplicação ao caso concreto. ${ }^{28}$

Assim, o ato interpretativo (parte) seria resultado de um conjunto de atos interpretativos, não separáveis do seu conjunto (todo), salvo hipoteticamente, e a compreensão do contexto fático - do mundo vivido - não deixaria de ser o seu fundamento.

[...] A norma jurídica é o resultado da interpretação. Interpretação que - sabemos - não é só do texto escrito e da própria realidade, no momento histórico no qual se opera a interpretação - , mas também dos fatos. [...] Para se passar da normatividade mediata para a normatividade concreta, a norma jurídica precisa de revestir o caráter de norma de decisão. Em suma, a norma de decisão é a norma jurídica aplicada a um caso concreto. ${ }^{29}$

Pelo ponto de vista apresentado no texto acima, se concluiria que a tese apresentada pelo STJ, para justificar a não-apreciação do aspecto material dos recursos especiais, não deve ser entendida como um consenso doutrinário, como se fosse um dogma, mas tão somente uma hipótese plausível. Além disso, o texto mostra a complexidade da interpretação jurídica, envolvendo o texto jurídico, o contexto de sua aplicação e os fatos concretos aos que se quer aplicar o ordenamento jurídico.

Quanto a aplicação do Enunciado n. ${ }^{\circ} 7$ da Súmula do STJ, considerada a separação dicotômica entre as questões jurídicas de fato e de direito, haveria uma proposta de sua revisão desse enunciado, por Danilo Knijnik, com base em "questões mistas".

[...] a contribuição da Teoria Tricotômica pretende ser o desenvolvimento de uma categoria autônoma que possibilite a interpretação da Súmula 7 do STJ de maneira a abarcar as

${ }^{28}$ MELLO, Marcos Bernardes de. Teoria do fato jurídico: plano da existência. 11. ed. São Paulo: Saraiva, 2001. p. 134-135. (grifo do autor)

${ }^{29}$ GRAU, Eros Roberto. Ensaio e discurso sobre a interpretação/aplicação do direito. 3. ed. São Paulo: Malheiros, 2005. p. 97-99. 
questões mistas. [...] definir um critério que selecione entre as questões mistas quais seriam passíveis de revisão. ${ }^{30}$

Por esse modo de ver, a interpretação da Súmula do STJ (Enunciado de n. ${ }^{\circ} 7$ ) levaria em conta os casos concretos onde não fosse possível estabelecer uma separação lógico-formal entre a análise dos fatos e a questão de direito, embora desprezando as questões puramente de direito material.

Não se conhecerá do Recurso Especial tendo por objeto questões preponderantemente fáticas. As questões mistas, entretanto, poderão ou não ser revisadas “in jure”, desde que certos requisitos se façam presentes, quais sejam (1) a existência de dúvida quanto à observância da margem de decisão e (2) a possibilidade, ao ensejo de revisá-la, de proceder-se a um desenvolvimento posterior do direito, circunscrevendo seu âmbito de aplicação. ${ }^{31}$

Diante das afirmações acima, caberia perguntar sobre a forma dogmática de adoção da inviabilidade do reexame de provas, quando não seria possível realizar a separação em relação aos fatos da causa em exame. Como esta argumentação dogmática é a única apresentada pelo STJ ao vedar o reexame de provas, a valoração que o órgão pratica poderia ser interpretada como uma forma de reconhecimento, implícito, da dificuldade em resolver o problema de uma concepção doutrinária rígida.

\subsection{Os paradoxos resultantes da distinção entre reexame e valoração}

Demonstrado que a argumentação doutrinária do STJ, na fundamentação de decisões no exame de recursos especiais, seria suscetível de questionamento teórico, seria oportuna a verificação sobre como acontecem essas decisões, com julgamento parcial do mérito sem exame integral da causa. Além disso, a decisão

${ }^{30}$ COSTA, Henrique Araújo. Reexame de prova em recurso especial: a súmula 7 do STJ. Brasília: Thesaurus, 2008. p. 225.

${ }^{31}$ KNIJNIK, Danilo. O recurso especial e a revisão da questão de fato pelo Superior Tribunal de Justiça. Rio de Janeiro: Forense, 2005. p. 239 apud COSTA, Henrique Araújo. Reexame de prova em recurso especial: a súmula 7 do STJ. Brasília: Thesaurus, 2008. p. 226. 
do STJ com fundamento em precedentes ensejaria uma interferência sobre a liberdade de decisão dos julgadores. ${ }^{32}$

Nesse particular, o comportamento do STJ mostraria a necessidade de se estabelecer qual a finalidade precípua da sua atuação como corte recursal extraordinária: se realizar procedimentos destinados a cassação de decisões judiciais, devolvendo a matéria à apreciação da instância inferior ou, proceder diretamente a revisão dessas decisões. Em relação à cassação, a doutrina define que é o procedimento de anulação do julgado, devolvendo a matéria a uma nova apreciação do tribunal de origem, enquanto na revisão, o próprio tribunal julgaria o recurso, reapreciando o mérito da causa como um todo.

Acontece que, segundo a doutrina, o modelo recursal brasileiro seria híbrido, com características de cassação e de revisão, levando a conclusão, por alguns doutrinadores do processo, que o sistema seria preponderantemente revisional, embora alguns estudiosos considerem existir uma faculdade de anulação do julgado.

Não há no processo civil brasileiro recurso de cassação, onde o tribunal superior cassa o acórdão do tribunal inferior e lhe devolve os autos para que seja proferida nova decisão. Os nossos recursos constitucionais têm aptidão para modificar o acórdão recorrido. $\mathrm{O}$ provimento, tanto do recurso especial quanto do extraordinário, tem como conseqüência fazer com que o STF e o STJ reformem ou anulem o acórdão recorrido. ${ }^{33}$

Observa-se do texto acima que, em relação ao STJ, este procederia a revisão de julgados, o que chegou a realizar, com fundamento na regra da Súmula 456 do STF, pela qual seria viável o exame integral do mérito recorrido. Contudo, esse procedimento com base na Súmula 456 foi objeto da manifestação do STF, o qual foi contrário à utilização da sua súmula com essa finalidade.

${ }^{32} \mathrm{O}$ papel das súmulas nas decisões do Poder Judiciário é assunto atual a exemplo do debate sobre a súmula de efeito vinculante da Emenda Constitucional n. ${ }^{\circ} 45$, de 08/12/2004, do art. 103-A. In: TUCCI, José Rogério Cruz e. Precedente judicial como fonte de direito. São Paulo: Revista dos Tribunais, 2004. p. 279-283.

${ }^{33}$ NERY JR., Nelson. Teoria geral dos recursos. 6 ed. São Paulo: Revista dos Tribunais, 2004. p. 441 apud COSTA, Henrique Araújo. Reexame de prova em recurso especial: a súmula 7 do STJ. Brasília: Thesaurus, 2008. p. 208. 
Do que dá exemplo o Recurso Extraordinário n. ${ }^{\circ}$ 202.668/DF, relator Ministro Néri da Silveira, 2a Turma, em 12/12/2000, onde o STF decidiu cassar a decisão do STJ, como também devolver a apreciação da matéria ao tribunal da instância ordinária, conforme transcrição que se segue.

EMENTA: Recurso extraordinário. Processual Civil. Recurso especial conhecido. 2. Acórdão que, com base na Súmula 456, do STF, tendo conhecido do recurso, julgou a causa, reapreciando a prova dos autos, para dar pela procedência da ação. 3. Supressão da instância da prova quanto ao exame do documento novo comprobatório da quitação do imóvel, considerado no aresto recorrido. Ofensa aos princípios da ampla defesa e do contraditório. 4. Não era viável ao STJ, no caso, com invocação da Súmula 456, desde logo, julgar o mérito da causa, examinando, originariamente, prova que a recorrida se encarregara de sustentar, no recurso especial, que, por omissão reiterada, a Corte de segundo grau deixara de analisá-la e emprestar-lhe significação. 5. Recurso conhecido e parcialmente provido para cassar, em parte, o acórdão do STJ, ao prover o recurso especial, com base na Súmula 456 do STF. 6. Retorno dos autos ao Tribunal de Justiça para renovar-se o julgamento dos embargos infringentes, com o específico exame da alegação e da prova apresentada, relativa à quitação do débito pertinente ao imóvel, dentro do conjunto probatório. ${ }^{34}$

Nesse ponto fica evidenciada divergência entre a jurisprudência do STF e a doutrina processual sobre os conceitos de revisão e cassação, ao entender o STF que a aplicação da Súmula STF 456 não poderia ensejar a supressão de instância ou a análise do conteúdo fático-probatório, ratificando o ponto de vista, que no modelo peculiar brasileiro não haveria revisão de julgados na ocorrência de erros de procedimento.

Contudo, no pensamento de alguns doutrinadores, prevaleceria a situação híbrida, na qual caberia aos tribunais extraordinários (STF e STJ) modificar o teor da decisão recorrida, ao invés de devolver a decisão ao órgão para novo julgamento.

${ }^{34}$ SUPERIOR TRIBUNAL DE JUSTIÇA. Disponível em: http://www.stj.jus.br/SCON/ pesquisar.jsp. Acesso em: 15 out. 2008. 
O Recurso Especial aproxima-se da revisão, mas pode, e não raro opera, como uma verdadeira cassação, especialmente quando exercita sua função disciplinar. Nesse caso, o Tribunal anula a decisão e a reenvia ao Tribunal Estadual, para que este prossiga no julgamento. Tal ocorre, sobretudo, nos casos de errores in procedendo." 35

A desconsideração do papel revisional dos tribunais na instância recursal extraordinária, afirmada pelo STF, não solucionou o problema da valoração da prova: o STJ reexamina provas, quando entende necessário, sem uma regra explícita a respeito. Fato que demanda uma investigação sobre os fundamentos apresentados pelo STJ para essa prática, onde ganhariam relevância as referências históricas em que se baseiam suas decisões.

Quando não havia norma sobre reexame de provas, as decisões do STJ tinham por base a analogia com a jurisprudência do Supremo Tribunal Federal, estabelecendo uma tradição de afinidade com os procedimentos praticados pelo Pretório Excelso, estabelecendo, a partir daí um dos critérios de estabelecimento da verdade no RESP.

Sem questionar as situações concretas e a natureza filosóficas das posições adotadas pelo STF, o STJ não tomou a iniciativa de estabelecer seus próprios critérios de análise. Com isso, acabou por criar um "senso comum", sobre o cabimento dos recursos de natureza extraordinária, como no Recurso Especial n. ${ }^{\circ}$ 67, Relator Ministro Barros Monteiro, 4a Turma, em 22/08/1989.

O STJ apreciou o pedido de reexame de prova, recorrendo à súmula do STF: “[...] Discussão sobre a validade de títulos de domínio e alegação de fraude à execução. Reexame de matéria de fato inadmissível no âmbito do recurso especial. Impertinência, no caso, da Súmula 621 do STF. Recurso não conhecido." ${ }^{36}$

Nesse julgamento recorreu à Súmula do STF para fundamentar sua decisão,

\footnotetext{
${ }^{35}$ KNIJNIK, Danilo. O recurso especial e a revisão da questão de fato pelo Superior Tribunal de Justiça. Rio de Janeiro: Forense, 2005. p. 107. Apud COSTA, Henrique Araújo. Reexame de prova em recurso especial: a súmula 7 do STJ. Brasília: Thesaurus, 2008. p. 206.

${ }^{36}$ SUPERIOR TRIBUNAL DE JUSTIÇA. Disponível em: http://www.stj.jus.br/SCON/ pesquisar.jsp. Acesso em: 24 mar. 2009.
} 
o que veio a se repetir inúmeras vezes. Assim, a vedação de reexame e a valoração da prova, nos recursos especiais, são um verdadeiro mecanismo de filtragem de recursos. ${ }^{37}$

Em relação aos procedimentos de controle do cabimento pelo STJ, chama a atenção na pesquisa é que, em nenhum caso da amostra realizada, houve a fundamentação de julgado, em exame de cabimento de RESP, com referência a quaisquer das alíneas do art. 105, III, da Constituição Federal. Por outro lado, na perspectiva do STJ, o primeiro indício da validade do RESP seria o prequestionamento da matéria - situação fática da instância recursal ordinária - requisito que seria uma precaução antecipada, de modo a não admitir matérias que pudessem invadir a competência recursal ordinária, pelo exame de fatos e provas, ensejando uma eventual supressão de instância.

A justificativa desses "filtros" nos recursos especiais aconteceria nos "precedentes", que estabelecem a verdade dos autos ignorando a situação específica de cada caso. O paradoxo dessa situação aparecerá adiante, quando for verificado como o STJ realiza a "valoração da prova", típica das situações mistas, referida, deixando em aberto os motivos dessa prática que se evidencia sem uma maior fundamentação doutrinária ou legal.

\subsubsection{A necessidade de prequestionamento da matéria do recurso}

O prequestionamento seria a maneira pela qual o STJ exige uma participação do tribunal de origem na questão legal suscitada, sem o que não conhece do recurso, alegando supressão de instância, conforme dá exemplo o Agravo Regimental no Agravo de Instrumento n. ${ }^{\circ}$ 73.646/SP, relator Ministro Cid Flaquer

\footnotetext{
${ }^{37}$ Segundo Henrique de Araújo Costa: [...] No fim, temos um regime próprio, cujo molde é a pretensamente científica vedação do reexame de fato. O problema se coloca nesses termos: se a vedação do reexame de fato é relevo importantíssimo para o cabimento do recurso, há parâmetro seguro para a sua fixação? [...] impossibilitado de prestar um serviço num tempo razoável, a vedação da análise da matéria fática pode acabar servindo de subterfúgio. [...] Não há erudição que afaste o conhecimento da prática. In: COSTA, Henrique Araújo. Reexame de prova em recurso especial: a súmula 7 do STJ. Brasília: Thesaurus, 2008. p. 207.
} 
Scartezzini, julgado pela 5a Turma em 07/05/1996: “[...] Mesmo que a questão tenha surgido somente no julgamento do apelo, faz-se indispensável o prequestionamento, sob pena de supressão de instância." ${ }^{38}$

Em decorrência, a decisão do STJ examina apenas esse mérito (questões de direito) e não o que seria o motivo do recurso, não havendo vinculação do exame do STJ com o conteúdo da sentença e do recurso da apelação. Nessa mesma linha, o STJ manifestou-se no Recurso Especial n. ${ }^{0} 915.258 /$ SP, relator Ministro Arnaldo Esteves Lima, $5^{\text {a }}$ Turma, em 05/02/2009, 5a Turma, conforme a ementa do acórdão, com a transcrição parcial a seguir. ${ }^{39}$

4. A teor da pacífica e numerosa jurisprudência, para a abertura da via especial, requer-se o prequestionamento, ainda que implícito, da matéria infraconstitucional. Hipótese em que o Tribunal de origem não emitiu nenhum juízo de valor acerca da questão envolvendo a suposta nulidade da cláusula contratual que prevê a renúncia do benefício de ordem dos fiadores. Súmulas 282/STF e 211/STJ.

Em relação a esse julgado, o fundamento foi duplo: a jurisprudência do STF (Súmula n. ${ }^{\circ}$ 282) e a Súmula STJ n. ${ }^{\circ} 320$, de 05/10/2005: "A questão federal somente ventilada no voto vencido não atende ao requisito do prequestionamento.", concluindo-se que a manifestação do órgão recorrido deve ser aprovada no acórdão atacado.

Logo, a verdade formal teria característica própria, tendo por regra "O que não está nos autos, não está no mundo..." e o cabimento em RESP levaria em conta apenas o acórdão recorrido: "O que não está no prequestionamento, não está no RESP".

\footnotetext{
${ }^{38}$ SUPERIOR TRIBUNAL DE JUSTIÇA. Disponível em: http://www.stj.jus.br/SCON/ pesquisar.jsp. Acesso em: 24 mar. 2009.

${ }^{39}$ Ibidem.
} 


\subsubsection{0 argumento do efeito de supressão de instância}

Do que foi exposto se verifica uma correlação entre prequestionamento e controle da supressão de instância, onde o STJ invadiria a competência do tribunal recorrido, se abordada matéria não debatida no acórdão, embora sem um conceito formalmente definido.

No Agravo Regimental no Agravo n. ${ }^{\circ} 77.602-R S$, Relator Ministro José de Jesus Filho, julgamento em 18/09/1995, 1a Turma, foi reafirmada a regra: “[...] E se o acórdão impugnado não debateu a norma contida no art. 462 do CPC não cabe a esta Corte apreciá-la, sob pena de suprimir uma instância. Daí a incidência das Súmulas 282 e 356 do STF." 40

Logo, a decisão acima correlacionou a supressão de instância com a matéria não debatida pelo tribunal recorrido, como no Recurso Especial n. ${ }^{\circ} 61.615-8 / \mathrm{RN}$, Relator Ministro Demócrito Reinaldo, $1^{a}$ Turma, em 25/10/1995: “[...] Se o acórdão impugnado não houver decidido expressamente as questões jurídicas constitutivas do fundamento do especial, esta Corte não poderá apreciá-las, sob pena de suprimir uma instância..."1

Com base nessa decisão, presume-se que em face da omissão do órgão recorrido, o RESP não pode ser apreciado: a despeito da lei ser descumprida, não haverá o controle extraordinário a esse respeito, à falta de prequestionamento da tese.

Em sede de Embargos Declaratórios no Recurso Especial n. ${ }^{\circ}$ 326.097/CE, relator Ministra Denise Arruda, 1a Turma em 17/08/2004, o posicionamento de observância da não supressão de instância por motivo de falta de prequestionamento foi mantido:

[...] 2. Assim, considerada a atual composição da lide, questões acerca da competência para o processamento do feito devem ser analisadas nas instâncias ordinárias, sob pena de supressão de grau de jurisdição e em observância

\footnotetext{
${ }^{40}$ SUPERIOR TRIBUNAL DE JUSTIÇA. Disponível em: http://www.stj.jus.br/SCON/ pesquisar.jsp. Acesso em: 24 mar. 2009.

${ }^{41}$ Ibidem.
} 
à ausência de prequestionamento da matéria, quando da interposição do especial. ${ }^{42}$

Conforme essa decisão o prequestionamento (tese do acórdão recorrido) seria condição indispensável da apreciação dos recursos especiais, o que ratificaria a constatação da pesquisa, em relação às decisões judiciais consultadas, pela inexistência de julgados onde a fundamentação do cabimento tenha ocorrido a partir de fatos ou provas, configurando alguma das situações do art. 105, III, da Constituição Federal de 1988.

Nesse caso, o STJ não apreciou quesito jurídico por não ter sido prequestionado, alegando supressão de instância, um paradoxo em relação aos casos em que há valoração da prova, descaracterizando seu reexame, quando o tribunal julga ex officio.

Como forma de explicitação desse paradoxo, há o Embargo Declaratório no Recurso Especial n. ${ }^{\circ}$ 768.419-SC, Relator Ministro Hélio Quaglia, julgado em 06/04/2006, na 6 ${ }^{\mathrm{a}}$ Turma, onde ficou decidido que a reinterpretação do significado de fatos considerados no acórdão, não é motivo de violação do enunciado n. 7 da Súmula do STJ.

[...] 'Não ofende o princípio da Súmula 7 emprestar-se, no julgamento do especial, significado diverso aos fatos estabelecidos pelo acórdão recorrido. Inviável é ter como ocorridos fatos cuja existência o acórdão negou ou negar fatos que se tiveram como verificados'. (AgRg no ERESP 134108/DF; Rel. Min. Eduardo Ribeiro. Corte Especial, in DJ 16.08 .1999 , p. 36). ${ }^{43}$

Do trecho acima, se conclui que o acórdão recorrido é o único ponto de análise de cabimento pelo STJ, tornando-se assim, o critério de verdade, em substituição ao princípio dispositivo (verdade formal), realizando-se, por analogia, a criação de um novo brocardo: “O que não está no acórdão recorrido, não está no mundo do recurso especial."

\footnotetext{
${ }^{42}$ Ibidem.

${ }^{43}$ SUPERIOR TRIBUNAL DE JUSTIÇA. Disponível em: http://www.stj.jus.br/SCON/ pesquisar.jsp. Acesso em: 24 mar. 2009.
} 
Diante da situação acima, conclui-se que o critério do STJ é no sentido de uma permanente orientação quanto aos termos da aprovação do acórdão recorrido, atuando sempre conforme essa rotina do tribunal, verdadeiro senso comum, sem recorrer jamais à interpretação de textos legais, visando alterar os julgados levados ao seu conhecimento.

\subsubsection{Os precedentes como única justificativa de convencimento}

A idéia do STJ como órgão de controle da interpretação das leis federais, implica que suas decisões teriam por base as disposições constitucionais a seu respeito ou mesmo a própria legislação federal questionada. Entretanto, o STJ adota prática da reiteração de decisões de mesmo assunto, às vezes com a transcrição na íntegra do seu teor.

Como no Recurso Especial n. ${ }^{\circ}$ 982-RJ, relator Ministro Gueiros Leite, julgado pela 3 a Turma, em sua sessão de 31/10/1989, com o seguinte teor: “[...] RECURSO ESPECIAL. REEXAME DE PROVA. O reexame de prova não se harmoniza com a índole do REsp, a exemplo do que ocorria com o RE (STF, Súmula n. ${ }^{0} 279$ ).”44

Na verdade o precedente evidenciaria um comportamento não usual no direito positivo, já que a recorrência a precedentes seria característica da concepção do direito fundado nos costumes (Commom Law), motivo pelo qual haveria semelhanças entre o direito costumeiro e o cabimento do RESP pelo STJ, inclusive na revisão de decisões.

[...] A própria abordagem ao direito de commom law se mostra bastante complicada na medida em que a doutrina parte sempre de precedentes. E é somente isso que existe sobre este assunto: um caótico grupo de precedentes. Ora, se a jurisprudência deriva de um jogo problemático, é natural que existam decisões que fujam a qualquer critério científico. Não obstante sua pouca importância, chamam atenção - para quem insiste em um caminho metodológico,

${ }^{44}$ SUPERIOR TRIBUNAL DE JUSTIÇA. Disponível em: http://www.stj.jus.br/SCON/ pesquisar.jsp. Acesso em: 24 mar. 2009. 
como é o caso de Knijnik - e sua análise serve de estímulo a que se construa um critério científico que as abarque. ${ }^{45}$

Conforme se depreende do texto acima, a evidência é que a instância de revisão somente modificaria o mérito de questão de direito, mas não atuaria em relação aos fatos e provas, os quais seriam da competência do juiz da causa, na primeira instância, de forma similar ao que acontece no cabimento dos recursos especiais no STJ.

[...] Diante disso, renasce a nossa velha questão, embora vista sob outra ótica, dado que o problema de distinção brota ainda na instância de apelação, seja na revisão de decisões em que participaram júri, seja naquelas em não se prevê sua participação. De uma forma ou de outra, é sempre o juiz de primeira instância que diz o direito, seja a partir da resposta aos quesitos por ele formulados, seja com base em seu próprio juízo. A partir daí, a instância de apelação é competente apenas para a revisão da matéria de direito, a não ser que se verifique exceção legal consistente em permitir a revisão no caso de a conclusão de primeiro grau ser claramente equivocada. Como se vê, o mesmo problema, sob novos contornos: "trata-se de um problema universal." $^{46}$

Nesse sentido, a afirmação transcrita permite estabelecer uma identidade entre o procedimento informal praticado pelo STJ e a revisão na forma do "Commom law", onde o juiz da apelação aprecia questões de direito - mas não de fato ou de provas - sendo possível identificar essa prática com a idéia da questão mista, na qual haveria a possibilidade da revisão parcial de questões de fatos e provas.

[...] Desborda do escopo deste trabalho ambientar em detalhes o que vem a ser o modelo de commom law. O que importa é saber que dentro dessa família do direito costumeiro foi forjado conceito importantíssimo ao fim deste trabalho, qual seja, o conceito de questões mistas (mixed questions), principalmente pelo o que o conceito significa para o desenvolvimento da Teoria Tricotômica de Knijnik. Vale registrar, desde o início, que esta escola não tem a distinção entre cassação e revisão vista pela mesma

${ }^{45}$ COSTA, Henrique Araújo. Reexame de prova em recurso especial: a súmula 7 do STJ. Brasília: Thesaurus, 2008. p. 202.

${ }^{46}$ COSTA, Henrique Araújo. Reexame de prova em recurso especial: a súmula 7 do STJ. Brasília: Thesaurus, 2008. p. 199-200. 
ótica que nós. Isto porque, embora reflexamente se cuide de uma questão importante, o que impera é uma distinção entre juiz e jurado, pela qual se atribui ao judge a questão de direito e ao juror a questão de fato. ${ }^{47}$

Em conclusão ao que foi transcrito acima, observa-se que além do STJ fundamentar sua análise de questões de fato e de direito em forma análoga ao que é procedido no "Commom Law", o tribunal também adota, em relação aos seus precedentes, a mesma concepção do direito costumeiro, inclusive quanto à indefinição dos critérios técnicos de formação do livre convencimento motivado dos seus julgadores.

O STJ ao adotar a valoração da prova, além de confrontar o enunciado n. ${ }^{\circ}$ 7, não utiliza o texto constitucional ou em algum dispositivo legal específico para decidir, impossibilitando a isonomia nas decisões judiciais.

\subsubsection{A valoração da prova aplicada em casos concretos}

Embora o conceito de valoração da prova não seja formalmente definido na jurisprudência do tribunal, sua idéia estendeu-se ao campo doutrinário, de forma que passou a ser uma assertiva, quase dogmática, falar em uma realização de valoração de prova no STJ.

A jurisprudência do tribunal mostra que a valoração das provas a que recorre o STJ tem um duplo procedimento: primeiro, acontece a seleção dos precedentes na jurisprudência pacificada do tribunal; depois, em casos previamente definidos, acontece o reexame das provas, sob o argumento da apreciação de questão de direito.

A valoração da prova pelo STJ acontece, principalmente, em casos de comprovação de tempo de serviço em atividade rural, para concessão de aposentadoria pelo Instituto Nacional do Seguro Social - INSS, contudo há outros precedentes

${ }^{47}$ Ibidem. p. 199. 
de reexame de prova, sob esse título, sem aplicação do Enunciado n. ${ }^{\circ} 7$ da Súmula do tribunal.

São conhecidas também decisões em casos de arbitramento de valores indenizatórios e da comprovação de fatos e situações feita mediante certidões. E há, ainda, os casos da fixação de honorários profissionais e do ressarcimento de danos por responsabilidade civil, em situações de exorbitância do valor estipulado, do valor irrisório ou do valor irreal.

No caso da legitimidade de documento na comprovação de tempo de serviço militar em operações bélicas, há o Agravo Regimental no Recurso Especial n. ${ }^{\circ}$ 731.271-RN, relator Ministro Félix Fisher, 5a Turma, em 02/06/2005: “[...] O Certificado de Reservista de $1^{\text {a }}$ Categoria - documento considerado pelo e. Tribunal a quo - não é apto a comprovar que o autor participou efetivamente de operações bélicas.". 48

Diante disso, caberia perguntar como o STJ trata exclusivamente da matéria legal se o argumento em que se baseou a decisão foi em relação à característica da prova apresentada, discordando inclusive do posicionamento do tribunal recorrido que a aceitou?

Quanto ao reexame de prova, visando à impugnação de valor fixado a título de verba honorária, o posicionamento do STJ é observado no Agravo Regimental no Agravo de Instrumento n. ${ }^{\circ} 880.879-R S$, relatora Ministra Denise Arruda, $1^{\text {a }}$ Turma, em 14/08/2007:

[...] Do exame dos autos, verifica-se que o juízo de primeiro grau, julgando procedentes os presentes embargos à execução fiscal, fixou a verba honorária em $\mathrm{R} \$ 2.500,00$ (dois mil e quinhentos reais), entretanto, o Tribunal de origem, em sede de apelação, majorou a verba honorária para " $10 \%$ (dez por cento) sobre o valor atualizado da causa", o qual foi fixado em R\$550.184,15, em dezembro de 1998.

\footnotetext{
${ }^{48}$ SUPERIOR TRIBUNAL DE JUSTIÇA. Disponível em: http://www.stj.jus.br/SCON/ pesquisar.jsp. Acesso em: 24 mar. 2009.
} 
2. Assim, sem desvalorizar o serviço prestado pelos procuradores da ora agravante, não se justifica a fixação de honorários advocatícios em tal valor ${ }^{49}$

Conclui-se da decisão transcrita, que o STJ não examinou nenhuma norma legal, que arbitrasse o valor ou vedasse a estipulação do percentual aplicado, tendo apenas manifestado seu pré-julgamento de exorbitância do senso comum. E ao proceder ao reexame das provas dos autos, para estabelecer o valor arbitrado dos honorários e a sua proporção em relação ao valor da sucumbência, o tribunal não atendeu a sua própria norma (Enunciado n. ${ }^{\circ}$ ), correndo ainda o risco da falta da isonomia na prestação jurisdicional..$^{50}$

Outro precedente de reexame de provas pelo STJ seria na definição do montante de indenização na reparação de dano civil, como no Agravo Regimental no Recurso Especial n. ${ }^{\circ}$ 857.294-SP, relator Ministro Ari Pargendler, 3a Turma, em 11/03/2008: “[...] O montante da indenização arbitrada para reparar o dano civil pode ser majorado no âmbito do recurso especial sem afronta à Súmula 7 do Superior Tribunal de Justiça.. ${ }^{51}$

Claramente o STJ no julgamento transcrito, adentra na prova processual para retificação de cálculos, recorrendo à presunção de exorbitância de arbitramento no juízo ordinário, realizando em seguida novo cálculo. Fato que comprovaria o reexame de provas, contrariando o enunciado da sua Súmula.

Essa valoração, característica de reexame de prova, seria evidenciada nos casos de comprovação de tempo de serviço em atividade rural. Como exemplo há o Agravo Regimental no Recurso Especial n. ${ }^{\circ}$ 881.215-SP, Relatora Ministra Maria Thereza Moura, 6a Turma, em 04/09/2008: “[...] 'em face das dificuldades encontradas pelo trabalhador rural [...] verificar as provas colacionadas nos au-

\footnotetext{
${ }^{49}$ SUPERIOR TRIBUNAL DE JUSTIÇA. Disponível em: http://www.stj.jus.br/SCON/ pesquisar.jsp. Acesso em: 24 mar. 2009.

${ }^{50}$ COSTA, Henrique Araújo. Reexame de prova em recurso especial: a súmula 7 do STJ. Brasília: Thesaurus, 2008. p. 272-273.

${ }^{51}$ SUPERIOR TRIBUNAL DE JUSTIÇA. Disponível em: http://www.stj.jus.br/SCON/ pesquisar.jsp. Acesso em: 24 mar. 2009.
} 
tos, com o fito de confirmar a atividade rural alegada, não se trata de reexame de prova, $[\ldots]^{\prime \prime}{ }^{52}$

Como visto, a verificação da prova fundada na equidade ensejou o reexame da prova, não reconhecido, no Agravo Regimental no RESP n. ${ }^{\circ}$ 903.972-SP, relatora Ministra Maria Thereza Moura, em 07/10/2008: “[...] Esta Corte já firmou o entendimento de que o exame da existência de início de prova material de trabalho rural não passa pelo reexame de matéria fático-probatória, mas sim pela simples valoração das provas carreadas aos autos,.".53

Questiona-se como não falar em reexame de provas, se o próprio tribunal entende estar tratando com provas parciais nos autos, o que enseja que nesse caso particular, não se recorreu ao Enunciado 7 para a recusa de apreciação da matéria ao argumento da diferença entre o direito material e direito formal.

A despeito dos casos concretos de valoração da prova, permaneceria a questão básica quanto à diferença entre reexame e valoração de provas, no cabimento dos recursos especiais, especialmente pelo fato que a fundamentação doutrinária do STJ não responde satisfatoriamente à alegada distinção entre questões de fato e de direito.

\subsection{0 efeito devolutivo no recurso especial}

O outro aspecto importante a considerar diz respeito ao efeito devolutivo em sede de recursos especiais, procurando verificar nos julgamentos do STJ como se dá sua aplicação, especialmente em vista do critério de julgamento do tribunal de apreciar precipuamente questões de direito e não de fato.

Segundo a doutrina majoritária, o efeito devolutivo é característica comum a todos os recursos, pelo qual o juízo "ad quem" somente tem poder de exame

${ }^{52}$ COSTA, Henrique Araújo. Reexame de prova em recurso especial: a súmula 7 do STJ. Brasília: Thesaurus, 2008. p. 202.

${ }^{53}$ SUPERIOR TRIBUNAL DE JUSTIÇA. Disponível em: http://www.stj.jus.br/SCON/ pesquisar.jsp. Acesso em: 24 mar. 2009. 
sobre a parte da decisão do juízo a quo que for impugnada, não sendo possível a existência de uma forma de impugnação genérica ou não precisa. ${ }^{54}$

O problema do efeito devolutivo nos recursos especiais no STJ, diz respeito ao fato que o tribunal não permite o exame do mérito integral impugnado, se limitando à apreciação das questões jurídicas apresentadas, contrariando assim, a própria definição daquele instituto recursal. ${ }^{55}$

[...] o efeito devolutivo traz consigo a própria essência dos recursos, vez que permite que o órgão julgador reaprecie a questão posta em juízo, desde que o recorrente aponte, nas suas razões, a irresignação no que toca à análise de determinada matéria. O pedido de nova decisão fixa os limites e o âmbito da devolutividade dos recursos (tantum devolutum quantum appellatum). O objeto da devolutividade é o mérito do recurso, a matéria que deverá ser apreciada pelo órgão julgador para prover ou improver o recurso. ${ }^{56}$

A natureza do efeito devolutivo limita a análise do órgão recursal, ao pedido da parte, o que não aconteceria no STJ, na apreciação de questões de fato, não o faz, enquanto em outras oportunidades, decide de forma diversa, quando na instância recursal ordinária, há garantia de revisão dos atos judiciais por dois órgãos (princípio do duplo grau de jurisdição). ${ }^{57}$

Segundo a doutrina processual o referido princípio não está expressamente previsto na Constituição Federal, embora a sua existência seja considerada como um desdobramento do princípio do Devido Processo Legal, do qual seriam deduzidos também os demais princípios da teoria geral do processo. ${ }^{58}$

${ }^{54}$ MIRANDA, Gilson Delgado. Processo civil: recursos. 3. ed. São Paulo: Atlas, 2002. p. 47.

${ }^{55}$ SOUZA, Bernardo Pimentel. Introdução aos recursos cíveis e à ação rescisória. 3. ed. ampl. e atual. São Paulo: Saraiva, 2004. p. 16.

${ }^{56}$ MENDONÇA, André Marinho. A concessão do efeito suspensivo ao recurso especial. Salvador: Faculdades Jorge Amado, 2007. p. 18. Disponível em: http://bdjur.stj.gov.br. Acesso em: 15 out. 2008.

${ }^{57}$ CINTRA, Antônio Carlos de A., GRINOVER, Ada P., DINAMARCO, Cândido R. Teoria geral do processo. 22. ed. São Paulo: Malheiros, 2006. p. 80.

${ }^{58}$ MIRANDA, Gilson Delgado. Processo civil: recursos. 3. ed. São Paulo: Atlas, 2002. p. 22. 
A existência do duplo grau de jurisdição, a despeito de sua previsão implícita, é reconhecida também na interpretação constitucional a respeito da competência dos tribunais para funcionar como órgãos recursais de $2^{\circ}$ grau. De onde decorre a idéia da aplicabilidade do princípio limitada, face às restrições das competências recursais. ${ }^{59}$

As peculiares do sistema brasileiro implicam, ainda, em exceções ao duplo grau de jurisdição, reduzindo-o ou estendendo-o, face às competências do Supremo Tribunal Federal - STF, do Superior Tribunal de Justiça - STJ e dos tribunais superiores, que ora podem atuar como instância originária ou como órgãos recursais de $3^{\circ}$ ou $4^{\circ}$ graus. ${ }^{60}$

De todo o exposto, é possível estabelecer que o duplo grau de jurisdição teria relação com as instâncias recursais ordinárias, como critério de garantia da prestação jurisdicional, ensejando o questionamento se a sua aplicação não seria viável nas instâncias recursais extraordinárias. Tal discussão ensejaria uma necessidade de mudança no comportamento atual do STJ, buscando a aplicação de um entendimento de natureza filosófica, de associação entre parte (o recurso especial) e o todo (a causa objeto do recurso).

Diante de tudo o que foi exposto, é possível se inferir que no procedimento adotado pelo Superior Tribunal de Justiça - STJ, em relação ao reexame do conteúdo fático-probatório nos recursos especiais, a justificação racional, tem como ponto de referência seus próprios julgados (precedentes), especialmente o Enunciado n. 7 da sua Súmula.

Não foi identificada decisão do STJ, com referência ao texto constitucional do art. 105, III (previsão do recurso especial), ou de qualquer outro diploma legal

\footnotetext{
${ }^{59}$ CINTRA, Antônio Carlos de A., GRINOVER, Ada P., DINAMARCO, Cândido R. Teoria geral do processo. 22. ed. São Paulo: Malheiros, 2006. p. 81.

${ }^{60}$ Segundo os autores,o STF atuaria como [...] órgão de superposição de terceiro ou até de quarto grau (art. 102, inc. III). Por sua vez, o Superior Tribunal de Justiça, o Tribunal Superior Eleitoral e o Tribunal Superior do Trabalho podem funcionar como órgãos de terceiro grau. In: Ibidem. p. 82.
} 
como base a vedação do reexame ou à aplicação seletiva da valoração da prova. As justificativas do STJ para a vedação ao reexame ou a valoração da prova seguem a linha divisória do Enunciado n. ${ }^{\circ}$ 7, pois antes da sua aprovação, recorria-se ao texto do enunciado n. ${ }^{\circ} 279$ da Súmula do STF e, após a criação da norma do STJ, a fundamentação passou a ser por aquele Enunciado.

Dessa forma, o ponto de partida da investigação sobre o tratamento do STJ à verdade formal, no cabimento dos recursos especiais, tem a ver com a avaliação do grau de utilização do Enunciado n. ${ }^{\circ} 7$ da Súmula do tribunal.

\section{Uma visão interdisciplinar do discurso jurídico}

O foco de investigação da monografia permite relacionar conceitos e teorias jurídicas com formulações teóricas e conceitos de outras áreas das ciências humanas, já que o itinerário de pesquisa, a partir da definição do seu escopo, implica na investigação de um uso da linguagem jurídica (texto), em uma área do direito (processual), a partir de um conceito da doutrina (princípio da verdade formal), no contexto histórico (1989 a 2009), de uma ação estatal (prestação jurisdicional), em relação a uma instituição jurídica definida (Superior Tribunal de Justiça), sob um dado rito (jurisprudência), tendo em vista a ocorrência de um comportamento concreto (aplicação de enunciado de súmula).

Essa primeira visão de conjunto do trabalho permite observar um ponto de interseção de três fontes do direito com suas formulações características: a interpretação (jurisprudência) de um princípio (doutrina), previsto no ordenamento jurídico (lei).

Contudo, o trabalho vai mais além, pois direciona a análise do tema a um referencial externo do direito (papel social), recorrendo a um processo de crítica das práticas institucionalizadas (ideologia), pressupondo, dessa forma, a existência de um comportamento social (discurso) em uma relação observável entre sujeito (operador jurídico) e objeto (conhecimento jurídico). Existindo o uso de um discurso característico (jargão jurídico), o qual não é uma linguagem criada 
para esse fim (não artificial), muitas vezes as percepções da realidade e as opiniões pessoais do operador jurídico (senso comum), se misturam com o seu referencial teórico, que já seria possível separar onde termina o juízo pessoal e onde começa o seu labor técnico (interpretação).

Dessa forma, o estudo pretendido mostra a necessidade de utilização de perspectivas de análise comum entre o direito e outras áreas das ciências humanas, em relação à linguagem, à ideologia, ao discurso e ao senso comum.

Tais conceitos são relevantes para a formação do operador jurídico, embora não tenham origem no direito, pois são critérios de definição da prática jurídica, de onde se extraem concepções utilizadas na prática cotidiana. Em vista disso, o referencial teórico apresentado tem em vista duas direções práticas: a relação interna ao direito pelo exame da sua teoria (hermenêutica jurídica) e a sua relação externa com as ciências sociais, pela crítica aos procedimentos adotados (conhecimento interdisciplinar).

Para os fins da monografia considera-se como um comportamento interdisciplinar a realização da idéia de que, não há campo de conhecimento humano onde se possa - por meio de teorias, pesquisas e práticas - abarcar todas as possibilidades de compreensão e de explicação da realidade, oferecendo respostas a todos os problemas. ${ }^{61}$

Deste modo, não serão aprofundadas nesta pesquisa as questões sobre a natureza e limites da interdisciplinariedade, nem sua definição em face de outras conceituações afins (multidisciplinariedade, pluridisciplinariedade e transdisciplinariedade). ${ }^{62}$

O que se pretende é salientar que a análise realizada na perspectiva do direito - sempre que necessário - recorre a outras áreas da ciência social, procedimento

\footnotetext{
${ }^{61}$ FAZENDA, Ivani Catarina A. Interdisciplinariedade: um projeto em parceria. 5. ed. São Paulo: Edições Loyola, 2002. p. 15.

${ }^{62}$ Ibidem. p. 31.
} 
que não é novo, a exemplo da aplicação dos conceitos lógicos na interpretação jurídica. $^{63}$

O direito não é uma realidade isolada do meio social, pois a forma de interpretação das suas fontes principais (a lei, a jurisprudência e a doutrina) e dos seus resultados recebe continuas influências em suas práticas e papéis desempenhados no plano político, econômico e social. ${ }^{64}$

Logo, a concepção do que venha a ser a hermenêutica jurídica não pode ser limitada à compreensão das normas positivadas, mas deve levar em conta a inserção do direito em uma complexidade social, sendo uma resposta às demandas e necessidades que o meio social lhe apresenta.

[...] O problema é que, quando colocado frente a frente à riqueza das relações sociais, o sistema normativo mostrase suscetível a não cumprir com seu mister existencial, encontrando-se as normas jurídicas, portanto, em xeque, pois a normatividade de parâmetros tradicionais claramente não mais corresponde à satisfação dos interesses sociais, plúrimos, multidimensionais, auto-reguladores. Afinal, as relações sociais mostram-se férteis, profícuas quanto à elaboração de normas válidas para o plano social, seguindo o esquema da pluralidade normativa. ${ }^{65}$

A partir dessa observação, se nota que há constante necessidade de atualização das formas a que o direito recorre para compreensão dos fenômenos jurídicos e não jurídicos, o qual é o contexto que prevalece na atualidade, onde o direito é provocado a rever suas concepções e formas de atuação na sociedade. Por outro lado, a complexidade do campo jurídico também importa a solução de problemas, como no caso da interpretação das fontes jurisprudenciais, a exemplo das súmulas.

${ }^{63}$ COSTA, Fábio Silva, Hermenêutica jurídica e direito contemporâneo: estudo acerca da operacionalidade do método interpretativo sistemático perante a redefinição paradigmática da ordem jurídica. São Paulo: Juarez de Oliveira, 2004. p. 33.

${ }^{64}$ Ibidem. p. 21.

${ }^{65}$ COSTA, Fábio Silva, Hermenêutica jurídica e direito contemporâneo: estudo acerca da operacionalidade do método interpretativo sistemático perante a redefinição paradigmática da ordem jurídica. São Paulo: Juarez de Oliveira, 2004. p. 72. 
[...] A Súmula define e redefine sentidos jurídicos. Em tais (re) definições são estabelecidos critérios de relevância visando a convencer o receptor a compartilhar o juízo valorativo postulado pelo emissor para o caso. Trata-se, pois, de uma definição persuasiva. ${ }^{66}$

Do texto acima, conclui-se que é de fundamental importância a compreensão das formulações da jurisprudência enquanto discurso jurídico, o qual se presta ao papel de justificar e oficializar comportamentos e preferências, as quais muitas vezes não se acham apresentadas de forma explicita.

Nesse contexto, cabe recorrer à definição de ideologia, como a prática ou conjunto de práticas, consciente ou inconscientemente realizadas, nas quais ocorrem uma ocultação das condições de existência e a justificação por argumentos racionais, de comportamentos individuais e coletivos, sem uma percepção crítica dos seus resultados.

[...] A ideologia processual faz com que os juristas deixem de ver que, por detrás do processo e das leis, encontramse interesses socialmente articulados e a visão de mundo de um grupo social específico e dominante. Isso explica o dogmatismo jurídico e a compreensão da relação entre 'mundo jurídico' e a interpretação que os 'práticos' elaboram do Direito, que, por meio de 'idéias falsas', ajudam a legitimar o poder político dominante (Mannheim). ${ }^{67}$

Como visto acima, a ideologia jurídica seria uma forma de não conhecer dos juristas sobre o próprio conhecimento, onde se acham ocultos os efeitos sociais e econômicos dos procedimentos, considerados neutros e fundamentados em uma racionalidade técnica inquestionável. Assim, a ideologia no direito assumiria uma dupla característica, entre os discursos propriamente jurídicos, e os outros discursos que permeiam sua prática.

No primeiro tipo, o "discurso do direito", seria a fala dos operadores jurídicos, prescrevendo e interpretando as normas jurídicas; enquanto no segundo, o

${ }^{66}$ STRECK, Lênio Luiz. Súmulas no direito brasileiro: eficácia, poder e função. Porto Alegre: Livraria do Advogado, 1995. p. 286-287. Ibidem. p. 24-25.

${ }^{67}$ HOMMERDING, Adalberto Narciso. Fundamentos para uma compreensão hermenêutica do processo civil. Porto Alegre: Livraria do Advogado, 2007. p. 120-121. 
“discurso jurídico", seria o conjunto das concepções de todos os participantes desse processo. ${ }^{68}$

Haveria assim, uma ideologia do direito (presente nas normas) e uma ideologia jurídica (presente nas concepções dos produtores do direito), ambas existindo como parte do mundo jurídico e também, de um contexto social mais amplo. ${ }^{69}$

Quanto à forma como se daria a manutenção e reprodução das ideologias no direito, se nota que ela aconteceria na formação acadêmica dos operadores jurídicos, os quais repetem no seu comportamento cotidiano e nas práticas discursivas, o que se convencionou chamar de senso comum teórico dos juristas.

O conceito de senso comum teórico pode ser definido como a ausência de questionamento dos fatos dados e das técnicas jurídicas tradicionais, as quais resultariam na perda de percepção da realidade social, cujo resultado seria o individualismo da interpretação normativa do Direito.

[...] Tudo isso passa a ter influência e importância na análise do Direito em nosso país. Como os juristas pensam o mundo e o Direito? Como se inserem e como têm acesso ao mundo? Isto porque, conforme bem assinalam Castanheira Neves e Ferrajoli, o universo jurídico deve ser compreendido como um universo lingüístico e se infere daí que o pensamento jurídico haverá de assumir como seu método específico a análise da linguagem - a análise da linguagem legal, isto é, a interpretação jurídica daqueles dados empíricos que consistem nas proposições normativas de que se compõe o discurso do legislador, e tendo decerto e radicalmente como objeto direto de análise o texto legal, os enunciados lingüísticos objetivados prescritivamente nesse texto. ${ }^{70}$

${ }^{68}$ Segundo Eros Grau: “[...] As distinções acima expostas encaminham outra, que opõe a ideologia do direito e a ideologia jurídica. Ideologia do direito é aquela portada pelos textos, pelos enunciados dos quais se extrai o sentido deôntico do direito. Ideologia jurídica é aquela produzida por quem usa ou fala do direito.. in: GRAU, Eros Roberto. Ensaio e discurso sobre a interpretação/aplicação do direito. 3. ed. São Paulo: Malheiros, 2005. p. 40.

${ }^{69}$ PASSOS, J. J. Calmon de. Cidadania tutelada. In: FERREIRA, Luiz Alexandre Cruz et al. Hermenêutica, cidadania e direito. Campinas, SP: Millenium Editora, 2005. p. 20.

${ }^{70}$ STRECK, Lênio Luiz. Hermenêutica jurídica $\mathbf{e}(\mathbf{m})$ crise: uma exploração hermenêutica da construção do direito. 7. ed. rev. atual. Porto Alegre: Livraria do Advogado, 2007. p. 60-65. 
Daí concluir-se que, não haveria possibilidade de uma interpretação jurídica, que fosse isenta de quaisquer pré-noções, mesmo se houvesse um auto-esclarecimento pleno de cada operador jurídico. Por outro lado, são essas mesmas pré-noções, que dão ao profissional do direito a orientação mínima, para que possa realizar sua tarefa interpretativa.

[...] Ou seja, no interior do sentido comum teórico dos juristas, consciente ou inconscientemente, o horizonte a partir de onde se pode e deve pensar a linguagem ainda é o do sujeito isolado (ou da consciência do indivíduo) - que tem diante de si o mundo dos objetos e dos outros sujeitos -, característica principal e ponto de referência de toda a filosofia moderna da subjetividade. ${ }^{71}$

Pelo exposto, se conclui que o conceito de senso comum teórico seria o ponto de partida da compreensão da linguagem jurídica, porém essa prática deve ser ponderada, de modo a não substituir uma forma ilusória de ver o mundo (naturalização do discurso jurídico) por outra equivalente (visão unilateral do direito).

[...] O senso comum faz coincidir causa e intenção; subjazlhe uma visão do mundo assente na ação e no princípio da criatividade e das responsabilidades individuais. O senso comum é prático e pragmático; reproduz-se colado às trajetórias e às experiências de vida de um dado grupo social e nessa correspondência se afirma de confiança e dá segurança. O senso comum é transparente e evidente; desconfia da opacidade dos objetos tecnológicos e do esoterismo do conhecimento em nome do princípio da igualdade do acesso ao discurso, à competência cognitiva e à competência linguística. ${ }^{72}$

Embora o texto acima ressalte as vantagens da utilização do conceito de senso comum, deve ser observado que a sua aplicação, no contexto jurídico, deve acontecer, de modo a assegurar que haja um processo crítico da própria análise da pesquisa, como forma de superação dos limites inerentes a esse conceito. Essa compreensão é importante, não apenas para o processo de reconhecimento das

\footnotetext{
${ }^{71}$ Ibidem. p. 93-94.

${ }^{72}$ SANTOS, Boaventura de S. Um discurso sobre as ciências. Porto: Afrontamento, 1987. p. 56. In: SANTOS, Boaventura de S. Introdução a uma ciência pós-moderna. 4. ed. Rio de Janeiro: Graal, 2003. p. 40.
} 
práticas adotadas pelo STJ na sua jurisprudência, como também em relação aos limites da pesquisa.

[...] Essa caracterização alternativa do senso comum procura salientar a positividade do senso comum, o seu contributo possível para um projeto de emancipação cultural e social. Em que condições ? Não cabe aqui falar senão das condições teóricas. [...] Daí, o conceito de dupla ruptura epistemológica: uma vez feita a ruptura epistemológica com o senso comum, o ato epistemológico mais importante é a ruptura com ruptura epistemológica. [...] Enquanto a primeira ruptura é imprescindível para constituir a ciência, mas deixa o senso comum tal como estava antes dela, a segunda ruptura transforma o senso comum com base na ciência. A dupla ruptura epistemológica é o modo operatório da hermenêutica epistemológica. Desconstrói a ciência, inserindo-a numa totalidade que a transcende. ${ }^{73}$

Do texto acima transcrito, importa observar que a mitigação dessa diferença entre conhecimento científico e conhecimento do senso comum implica que as teorias aqui apresentadas não devam ser aplicadas de modo absoluto, cabendo na pesquisa sua delimitação no seu contexto de aplicação. Desse modo, tanto o "senso comum teórico dos juristas", deve ser interpretado com moderação, como também as teorias a ele aplicadas, por fazerem parte do senso comum do pesquisador, influenciando em todo o processo de pesquisa.

Quanto à idéia de fetichização do discurso jurídico - a qual se contrapõe a fenômeno da naturalização, - embora com efeitos opostos - pode ser dito que acontece quando se procura ressaltar, de forma exagerada, o comportamento jurídico, não se permitindo um processo de autocrítica em relação aos seus fundamentos lógicos e à sua legitimidade.

[...] Como decorrência, pode-se dizer, a partir das lições de Servovich, que o discurso dogmático torna-se transparente, gerando uma cadeia significativa no interior da qual as sequências discursivas remetem o usuário/operador jurídico diretamente à realidade, mediante o processo de ocultamento das condições de produção do sentido do discurso. A este fenômeno podemos denominar de 'fetichização do discurso jurídico', é dizer, através do discurso

${ }^{73}$ Ibidem. p. 40. 
dogmático, a lei passa a ser vista como sendo uma-lei-em-si, abstraída das condições (de produção) que a engendraram, como se a sua condição-de-lei fosse uma propriedade 'natural'. Consequentemente, complementando com o mesmo Servovich, o discurso dogmático transforma-se em uma imagem, na tentativa (ilusória) de expressar a realidade-social-de-forma-imediata. ${ }^{74}$

Conforme referido acima, é possível estabelecer uma perspectiva das relações de poder no direito, recorrendo-se a noção de discurso jurídico, tendo como referência a análise das concepções de linguagem e da verdade. Como resultado do uso dos conceitos de senso comum teórico, naturalização/fetichização do discurso jurídico, em uma leitura da ideologia, torna-se possível associá-los ao "campo" e ao habitus. ${ }^{75}$

O conceito de campo tem a ver com a Teoria Geral da Economia dos Campos, elaborada por Pierrer Bourdieu, podendo ser definido - no ponto de vista da linguagem - como a reunião de pessoas, com os mesmos objetivos em comum, partilhando dos mesmos valores e visões de mundo.

[...] estrutura das relações entre os capitais lingüísticos ou culturais dos interlocutores ou de seus grupos. [...] a forma específica de que se revestem, em cada campo, os mecanismos e os conceitos mais gerais (capital, investimento, ganho), [...] apreender aquilo que faz a necessidade específica da crença que o sustenta, do jogo de linguagem que nele se joga, das coisas materiais e simbólicas em jogo que nele se geram. ${ }^{76}$

Em relação ao direito, seria possível a aplicação do conceito de campo, o qual poderia ser definido como o sistema em que há o monopólio da linguagem, que pode atuar na resolução de conflitos intersubjetivos, onde há uma divisão de trabalho e um modo de interpretação próprio do texto ali produzido.

${ }^{74}$ STRECK, Lênio Luiz. Hermenêutica jurídica e(m) crise: uma exploração hermenêutica da construção do direito. 7. ed. rev. atual. Porto Alegre: Livraria do Advogado, 2007. p. 60, 65.

${ }^{75}$ Ver o conteúdo do capítulo VIII - A força do direito: Elementos para uma sociologia do campo jurídico. In: BOURDIEU, Pierre. O Poder simbólico. Trad. de Fernando Tomaz. 11 ed. Rio de Janeiro: Bertrand Brasil, 2007. p. 209-254.

${ }^{76}$ BOURDIEU, Pierre. O Poder simbólico. Trad. de Fernando Tomaz. 11 ed. Rio de Janeiro: Bertrand Brasil, 2007. p. 69. 
[...] O campo jurídico é o lugar de concorrência pelo monopólio do direito dizer o direito, quer dizer, a boa distribuição (nomos) ou a boa ordem, na qual se defrontam agentes investidos de competência ao mesmo tempo social e técnica que consiste essencialmente na capacidade reconhecida de interpretar (de maneira mais ou menos livre ou autorizada) um corpus de textos que consagram a visão legítima, justa, do mundo social. ${ }^{77}$

Quanto ao conceito de habitus, intimamente relacionado ao de campo, pode ser conceituado como o conjunto de práticas que indicam a pertença de um indivíduo e grupo de indivíduos a um campo, “[...] é um conhecimento adquirido e também um haver, um capital (de um sujeito transcendental na tradição idealista) o habitus, a hexis, indica a disposição incorporada, quase postural -, mas sim o de um agente em ação [...]" ${ }^{78}$

Além dessa concepção da existência comum a um grupo, conforme referido no trecho acima transcrito, pelo qual esse conjunto de pessoas partilha a mesma linguagem, visão de mundo e práticas de trabalho, haveria também uma forma própria de interpretação do texto legal, pela atualização histórica da norma, renovando-a pela aplicação ao caso concreto.

[...] A interpretação opera a historicização da norma, adaptando as fontes a circunstâncias novas, descobrindo nelas possibilidades inéditas, deixando de lado o que está ultrapassado ou o que é caduco. Dada a extraordinária elasticidade dos textos, que vão por vezes até a indeterminação ou ao equívoco, a operação hermenêutica de declaratio dispõe de uma imensa liberdade. ${ }^{79}$

Não obstante a afirmação acima, sobre a liberdade da interpretação jurídica, conforme será visto em seguida, a interpretação jurisprudencial deixa dúvidas sobre as possibilidades alternativas de realização da interpretação, conforme apresentado na definição do problema de pesquisa no primeiro capítulo.

77 Ibidem. p. 212.

${ }^{78}$ Ibidem. p. 212.

${ }^{79}$ BOURDIEU, Pierre. O Poder simbólico. Trad. de Fernando Tomaz. 11 ed. Rio de Janeiro: Bertrand Brasil, 2007. p. 223. 
Com essas definições conceituais, o trabalho deve incorporar uma metodologia e uma prática de pesquisa que com eles sejam complementares, conforme será visto nos subitens seguintes.

\subsection{Uma noção acerca da verdade na perspectiva do processo civil}

O contexto no qual será aplicado o referencial teórico da pesquisa, demandou uma apresentação de conceitos e teorias do campo do direito, que fossem consideradas adequadas à análise do problema de valoração da prova no exame de cabimento dos recursos especiais pelo Superior Tribunal de Justiça - STJ.

Como o problema de pesquisa envolve também a efetividade do conceito de verdade formal e sua relação com o controle do livre convencimento do julgador, foi necessário recorrer à teoria dos princípios aplicada ao processo civil.

Contudo, a remissão à teoria dos princípios não objetiva uma apresentação completa do seu conteúdo e nem mostrar detalhadamente, o ponto de vista dos doutrinadores do assunto, mas delimitar o referencial jurídico, na análise do problema de pesquisa, sem desvirtuar a análise interdisciplinar do tema da monografia. Nesse sentido, a compreensão do papel dos princípios na teoria geral do processo torna necessária uma diferenciação entre as três espécies normativas: os princípios, as regras e os postulados normativos. ${ }^{80}$

Quanto à diferenciação entre princípios e normas, o tema é objeto de um debate de grande relevância, ainda não concluído, do qual fazem parte experientes filósofos do direito, tais como: Josef Esser, Karl Larenz, Claus Canaris, Ronald Dworkin e Robert Alexy, os quais poderiam ser diferenciados segundo sua visão doutrinária da distinção "fraca" ou "forte", entre os princípios e regras. ${ }^{81}$

\footnotetext{
${ }^{80}$ ÁVILA, Humberto. Teoria dos princípios: da definição à aplicação dos princípios jurídicos. 8. ed. São Paulo: Malheiros, 2008. p. 122.

${ }^{81}$ Ibidem. p. 39.
} 
No ponto de vista defendido por Josef Esser, a distinção entre princípios e regras estaria relacionada a uma diferença qualitativa, onde os princípios, diferentemente das regras, teriam uma função de fundamentação normativa para a tomada de decisões, como normas estabelecidas para a criação de outras normas. Tal visão parece estabelecer a linha clássica de pensamento sobre a natureza dos princípios. ${ }^{82}$

Para o pensamento de Karl Larenz, que seguiria, até certo ponto, a concepção dos princípios como fundamento normativo, haveria uma relação de complementariedade dos princípios em relação às regras, atuando os primeiros como enunciados normativos, que dirigem o trabalho de conexão entre a hipótese de incidência e o resultado da interpretação jurídica realizado pelas regras. ${ }^{83}$

Já no ponto de vista de Claus-Wilhelm Canaris, a distinção entre princípios e regras teria como foco o conteúdo axiológico dos primeiros, os quais não seriam passíveis de aplicação sem a formulação das regras. E, ainda, a diferença no modo de relacionamento dos princípios com as demais normas, pois contrariamente às regras, os princípios realizariam sua delimitação por um processo dialético de complementação e limitação.

No âmbito das contribuições da tradição anglo-saxônica, surgiram duas das mais importantes conceituações sobre o assunto, nas obras de Ronald Dworkin e de Robert Alexy, especialmente pela definição a respeito da natureza dos princípios. No modo de ver de Dworkin, os princípios teriam por característica a ausência de decisão, servindo apenas como fundamento, o que permitiria estabelecer a preponderância de um deles sobre aos demais.

[...] os princípios, ao contrário das regras, possuem uma dimensão de peso (dimension of weight), demonstrável na hipótese de colisão entre os princípios, [...] não consiste numa distinção de grau, mas numa diferenciação quanto à estrutura lógica, baseada em critérios classificatórios, em vez de comparativos, como afirma Robert Alexy. ${ }^{84}$

${ }^{82}$ Ibidem. p. 35.

${ }^{83}$ Ibidem. p. 36.

${ }^{84}$ ÁVILA, Humberto. Teoria dos princípios: da definição à aplicação dos princípios jurídicos. 8. ed. São Paulo: Malheiros, 2008. p. 37. 
Do que foi transcrito infere-se que a ênfase da análise de Dworkin acontece sobre a relação dos princípios entre si, daí decorrendo sua diferenciação em relação às regras, as quais seriam aplicadas sob a forma de uma rígida dicotomia: incidência ou não-incidência.

[...] Para ele as regras são aplicadas ao modo tudo ou nada (all-or-nothing), no sentido de que, se a hipótese de incidência de uma regra é preenchida, ou é a regra válida e a conseqüência normativa deve ser aceita, ou ela não é considerada válida. No caso de colisão de regras, uma delas deve ser considerada inválida. ${ }^{85}$

Como visto as regras se auto-excluiriam, não podendo coexistir em um conflito de aplicação, ao contrário dos princípios, que não perderiam sua validade pela escolha entre um e outro. ${ }^{86}$

As considerações de Dworkin levaram a uma reelaboração das concepções de princípios e regras por Robert Alexy. No pensamento de Alexy, os princípios seriam normas jurídicas apresentando deveres de otimização, considerando tanto as possibilidades normativas, como fáticas. Para o autor, não haveria uma definição de peso pela comparação da natureza entre princípios, mas a ponderação entre esses em caso concreto de conflito.

[...] nesse caso, a solução não se resolve com a determinação imediata da prevalência de um princípio sobre o outro, mas é estabelecida em função da ponderação entre os princípios colidentes, em função da qual um deles, em determinadas circunstâncias concretas, recebe a prevalência. ${ }^{87}$

Considerada essa natureza dos princípios, conforme visto acima, onde o conflito acontece em um mesmo plano, as regras teriam comportamento diferenciado, por se acharem sempre em planos diferentes, razão pela qual se optaria por uma em detrimento da supressão da outra (validade e não validade).

\footnotetext{
${ }^{85}$ Ibidem. p. 36.

${ }^{86}$ Ibidem. p. 37.

${ }^{87}$ ÁVILA, Humberto. Teoria dos princípios: da definição à aplicação dos princípios jurídicos. 8. ed. São Paulo: Malheiros, 2008. p. 37.
} 
[...] A distinção entre princípios e regras - segundo Alexy não pode ser baseada no modo tudo ou nada de aplicação proposto por Dworkin, mas deve resumir-se, sobretudo, a dois fatores: diferença quanto à colisão, na medida em que os princípios colidentes apenas têm sua realização normativa limitada reciprocamente, ao contrário das regras, cuja colisão é solucionada com a declaração de invalidade de uma delas ou com a abertura de uma exceção que exclua a antinomia; diferença quanto à obrigação que instituem, já que as regras instituem obrigações absolutas, não superadas por normas contrapostas, enquanto os princípios instituem obrigações prima facie, na medida em que podem ser superadas ou derrogadas em função dos outros princípios colidentes. $^{88}$

Com base no texto acima, se infere que essa seria a forma mais aperfeiçoada de tratamento das diferenças entre princípios e regras, ocorrendo, porém, em uma perspectiva mais recente da hermenêutica, que essa dicotomia entre princípios e regras fosse superada por uma divisão tripartite das normas jurídicas entre: princípios - regras - postulados. ${ }^{89}$

Na concepção mais atual da pesquisa hermenêutica, os postulados seriam regras que estabelecem modos de agir na aplicação de outras regras que os precederam. São normas tratando de normas ( $2^{\circ}$ grau $)$ ou metanormas.

[...] Por trás dos postulados, há sempre outras normas que estão sendo aplicadas. Não se identificam, porém, com as outras normas que também influenciam outras, como é o caso dos sobreprincípios do Estado de Direito ou da segurança jurídica. Os sobre princípios situam-se no nível das normas objeto de aplicação. Atuam sobre outras, mas no âmbito semântico e axiológico e não no âmbito metódico, como ocorre com os postulados. Isso explica a diferença entre sobre-normas (normas semântica e axiologicamente sobrejacentes, situadas no nível do objeto de aplicação) e metanormas (normas metodicamente sobrejacentes, situadas no metanível aplicativo). ${ }^{90}$

${ }^{88}$ Ibidem. p. 38-39.

${ }^{89}$ Ibidem. p. 71.

90 ÁVILA, Humberto. Teoria dos princípios: da definição à aplicação dos princípios jurídicos. 8. ed. São Paulo: Malheiros, 2008. p. 122. 
Do texto acima se conclui que os postulados normativos estabelecem comandos de orientação em relação a outras regras jurídicas, o que levaria a concluir que, no caso da Súmula do STJ, esta funcionaria como um postulado, pois orientaria, por seus enunciados, a decisão sobre o cabimento dos recursos.

Nesse raciocínio, o texto do Enunciado n. ${ }^{\circ}$ 7, "A PRETENSÃO DE SIMPLES REEXAME DE PROVA NÃO ENSEJA RECURSO ESPECIAL”, funcionaria como "postulado", pelo fato de estabelecer um critério de aplicação de outra norma: "Não admitir como recurso especial que não atenda aos requisitos de cabimento". ${ }^{11}$

Examinando a preliminar de exame de cabimento dos RESP, no art. 257 do Regimento Interno do STJ, percebe-se que o Enunciado n. 7 da Súmula do tribunal orientaria aquela norma genérica: "Art. 257. No julgamento do recurso especial, verificar-se-á, preliminarmente, se o recurso é cabível. Decidida a preliminar pela negativa, a Turma não conhecerá do recurso; se pela afirmativa, julgará a causa, aplicando o direito à espécie...92

Logo, os enunciados da Súmula do STJ não seriam princípios nem regras, mas postulados normativos, o que - embora não seja suficiente para definir sua natureza - permitiria a sua aplicação nos casos concretos apresentados no capítulo seguinte.

Feitas essas ponderações, cabe referência à teoria processual sobre os princípios, segundo a qual haveria uma cadeia hierárquica nas relações entre os mesmos, dos menos abrangentes ( $1^{\circ}$ grau) aos mais amplos ( $2^{\circ}$ grau $)$, vinculados aos mais gerais $\left(3^{\circ} \mathrm{grau}\right)$.

[...] o princípio do juiz natural informa todos os demais princípios ligados com à jurisdição e a pessoa do juiz; o princípio do acesso à justiça informa todos os demais princípios ligados à ação e à defesa; e o princípio do devido processo legal informa todos os demais princípios de primeiro graus ligados ao processo e ao procedimento. Por

\footnotetext{
${ }^{91}$ Ibidem. p. 139.

${ }^{2}$ SUPERIOR TRIBUNAL DE JUSTIÇA. Disponível em: http://www.stj.jus.br/SCON/ regimento/. Acesso em: 14 maio 2009.
} 
sua vez, os princípios do processo civil de primeiro e segundo graus são informados pelos princípios informativos ou formativos que, assim, são de terceiro grau. [...] Em verdade, os princípios de terceiro grau também são informados por princípios de um grau superior. Porém, nesse nível, já se está em sede dos princípios monovalentes que informam toda a ciência do direito. ${ }^{93}$

Do texto acima, observa-se que a precedência de um princípio sobre outros, partiria dos mais específicos até os mais abrangentes em uma sequência que chegaria aos princípios mais amplos, abarcando a compreensão de todo o Direito.

Além disso, os princípios não deveriam ser utilizados de forma literal e mecânica, ou isolados das situações concretas da sua aplicação, considerada a sua inter-relação e interdependência.

[...] Os princípios não são estanques ou absolutos. São relativos e por isso todos devem ser ponderados diante do caso concreto. Inter-relacionados e interdependentes, eles se ligam, se influenciam mutuamente e se combinam entre si e com outras ciências, jurídicas ou não. Os significados tanto se interpenetram e limitam a abrangência, como se excluem e são conflitantes entre si. [...] Ademais, nem todos os princípios têm previsão legal. Muitos (e às vezes os mais importantes, como, por exemplo, o da boa-fé no direito civil e o do interesse público no processo) são reflexos imediatos da realidade. ${ }^{94}$

Verifica-se, acima, que a aplicação dos princípios não deveria ser feita de forma isolada ou sem utilização de um caso concreto, dada a possibilidade de resultados diversos em cada situação concreta de sua aplicação, além de haver a necessidade de uma permanente atualização do seu conteúdo, levando em conta as demandas sociais e a realidade onde eles seriam aplicados, demandando também uma capacitação dos operadores jurídicos quanto ao seu papel no Direito e efeitos.

[...] Contudo, não pode ser desprezada tanto a indispensável atualização dos seus postulados em função da realidade e das necessidades sociais, com atendimento às peculiaridades de

\footnotetext{
${ }_{93}$ PORTANOVA, Rui. Princípios do processo civil. 7.ed. Porto Alegre: Livraria do Advogado, 2008. p. 14.

${ }^{94}$ Ibidem. p. 285.
} 
cada caso concreto. É indispensável, por isso, que o operador jurídico tenha visão interdisciplinar do fato e busque, além da norma, fatores de ordem social, política, econômica, geográfica e ideológica para uma adequada aplicação dos princípios. $^{95}$

Depreende-se do texto transcrito, que a formação interdisciplinar dos operadores jurídicos seria a condição necessária para promover a atualização dos princípios, levando em conta a influência das ideologias nas leis e nos princípios, sendo estes, os que melhor evidenciariam as motivações do seu intérprete.

[...] à semelhança das leis, não estão imunes às motivações ideológicas dos atores jurídicos. A qualidade, tanto da aplicação da norma como dos princípios, depende da fundamentação de quem interpreta. A vantagem dos princípios é possibilitar melhor desvendamento da ideologia do intérprete. Para tanto, é importante que o conteúdo do princípio seja amplo e aberto. ${ }^{96}$

Conclui-se com essa transcrição, ser necessária uma autocrítica do intérprete em relação às suas próprias convicções e interesses, sob pena de que a utilização do princípio seja eivada de concepções não percebidas, sujeitas à manipulação ideológica em detrimento da função social dos princípios.

Algumas vezes os princípios tomariam a forma de normas jurídicas, revestindo-se da força destas, como no caso do art. 130 do CPC, embora esse fato, não prejudique a importância dos demais princípios que não estejam positivados. ${ }^{97}$

Outro aspecto seria a sua inclusão entre os preceitos constitucionais, transformando a prática processual em mecanismo de viabilização dos direitos e garantias e, o legislador constitucional não teria fugido à ideologia da processualização, onde o papel do Poder Judiciário seria a promoção da mudança social.

\footnotetext{
${ }^{95}$ PORTANOVA, Rui. Princípios do processo civil. 7. ed. Porto Alegre: Livraria do Advogado, 2008.p. 285.

${ }^{96}$ Ibidem. p. 285.

${ }^{97}$ Os princípios embora não sejam parte do ordenamento jurídico (positivados), são considerados norma jurídica. In: GRAU, Eros Roberto. Ensaio e discurso sobre a interpretação/aplicação do direito. 3. ed. São Paulo: Malheiros, 2005. p. 159-161.
} 
[...] À efetividade e à segurança, como valores, aderiuse à democracia como valor instrumental. A motivação das decisões, a informação sobre os direitos, a discussão de questões jurídicas e a congruência entre o Judiciário e a sociedade nos objetivos perseguidos, garantem a legitimidade do mesmo como Poder e possibilitam o seu controle externo. ${ }^{98}$

\subsubsection{A oralidade como fundamento do discurso no processo civil}

Estabelecidas as condições de utilização dos princípios, caberia relacionar os princípios cujo papel seria mais destacado na formulação da verdade formal nos recursos especiais: a oralidade, a persuasão racional e o livre convencimento motivado do julgador. A importância da oralidade é observada no princípio do contraditório e da ampla defesa, pois "[...] regulam e direcionam as atividades do julgado, das partes e de todos os que participam do processo jurisdicional judicial, atuando diretamente sobre a regularidade, extraindo deles conseqüências práticas interpretativas ou integrativas.".99

Em relação ao contraditório, sua realização poderia ser algumas vezes dispensada, como no caso em que haja necessidade de realização de tutelas de urgência, quando a outra parte será ouvida oportunamente, excepcionalidade que não prejudica a idéia geral a respeito da utilidade dos princípios processuais. ${ }^{100}$

Além disso, seria adequada a utilização do princípio da oralidade aos casos concretos, pois "[...] teria a vantagem de estabelecer o contato do julgador com as partes que se submeterão à sua decisão, possibilitando um julgamento mais justo e com maior força de pacificação social." ${ }^{101}$.

${ }^{98}$ ZANETI JÚNIOR, Hermes. Processo constitucional: relações entre processo e constituição. In: MITIDIERO, Daniel Francisco. Introdução ao estudo do processo civil: primeiras linhas de um paradigma emergente. Porto Alegre: S. A. Fabris, 2004. p. 56.

99 SCHLICHTING, Arno Melo. Teoria geral do processo: concreta, objetiva, atual. 2. ed. Florianópolis: Momento Atual, 2004. p. 38.

${ }^{100}$ FUX, Luiz. Curso de direito processual civil. Rio de Janeiro: Forense, 2001. p. 227.

${ }^{101}$ BARROSO, Carlos Eduardo Ferraz de Mattos. Processo civil: teoria geral do processo e processo de conhecimento. Vol. 11, 3 ed. rev. São Paulo: Saraiva, 2000. p. 19. 
Quanto ao fato que a oralidade teria sido reduzida quase exclusivamente à forma escrita do discurso judicial, não há na doutrina um consenso a esse respeito, sendo reconhecida a coexistência entre a palavra falada e a escrita.

[...] não há exclusão mas aproveitamento da escrita, e mesmo acentuada, predominância quantitativa de atos escritos em combinação com a palavra falada como meio de expressão de atos relevantes e de decisiva influência na formação da convicção do juiz. Tira o sistema a denominação sistema oral, procedimento oral, ou apenas oralidade da circunstância de em momentos capitais do processo predominar a palavra falada; mas não somente nisso ele consiste, e sim também na aplicação de modos e formas segundo os quais se movimenta o processo e pelos quais a palavra falada surge e se mostra mais eficaz e conveniente que a palavra escrita.

Como visto, oralidade não se restringiria à forma falada do discurso, já que ela abarcaria qualquer ato de comunicação eficaz, entre as partes e sujeitos processuais e, nesse sentido, seria sinônimo da discursividade. Dessa forma, a doutrina reconhece que a oralidade não teria no processo uma forma "pura”, sendo impossível estabelecer uma separação entre atos exclusivamente falados e atos realizados apenas sob a forma escrita.

Quanto à forma dos atos processuais, o procedimento se desenvolve através do sistema oral e escrito. Atualmente, reconhece a doutrina que não existe procedimento oral na sua forma pura. Adota-se um procedimento misto, uma combinação do oral e do escrito.

Em contraposição, a multiplicidade de formas da oralidade seria reconhecida pelos que defendem que os princípios do procedimento oral (imediação, identidade física do juiz, concentração e irrecorribilidade das decisões interlocutórias), são indicadores de mudança, alternando entre expressões faladas e escritas.

No procedimento oral, existe uma predominância quantitativa de atos escritos, porém, em combinação com

\footnotetext{
${ }^{102}$ SANTOS, Moacyr Amaral. Primeiras linhas de direito processual civil: $2^{\circ}$ volume. 24. ed. rev. e atual. Por Maria Beatriz Amaral Santos Köhnen. São Paulo: Saraiva, 2008. p. 85.

${ }^{103}$ BARBOSA, Henry B. C. Manual de direito processual civil básico. 2 ed. Curitiba: Juruá, 2006. p. 186-187.
} 
a palavra falada, 'como expressão dos atos relevantes e decisivos na formação da convicção do juiz' . [...] A oralidade moderna representa um complexo de idéias e caracteres que se traduzem em vários princípios intimamente ligados entre si, que lhe dão aspecto particular [...].

Como visto acima, qualquer ato de comunicação que tenha por fim a otimização dos atos processuais, teria como meio de realização a oralidade, a qual se transformaria em referência da atuação processual, embora alguns doutrinadores entendam que ela se apresentaria sempre na forma textual, pois a prática oral é reduzida a termo.

[...] Os atuais ritos ordinário e sumário do procedimento comum de conhecimento fazem clara opção pela forma escrita, pois, com exceção da regra prevista no art. 132 do Código de Processo Civil (vinculação do juiz que encerra a audiência), não se encontram adotadas as demais características da oralidade pura, vislumbradas apenas no rito sumaríssimo do juizado especial cível. ${ }^{105}$

Pelo texto acima, a oralidade variaria segundo o rito processual adotado, carecendo a legislação processual de um estímulo explícito ao desenvolvesse de um processo de comunicação, visando atender as exigências de agilidade, segurança e clareza do processo.

\subsubsection{A verdade e o convencimento do julgador nas decisões judiciais}

A abordagem ao convencimento do julgador no processo civil teria a ver com o princípio da persuasão racional do juiz, conforme o art. 93, inciso IX, ratificado pela Emenda Constitucional n. ${ }^{\circ} 45$, de 2004. Seria obrigação do juiz fundamentar sua decisão com base os autos e não em sua convicção pessoal, por força da oralidade. ${ }^{106}$

\footnotetext{
${ }^{104}$ Ibidem. p. 187.

${ }^{105}$ BARROSO, Carlos Eduardo Ferraz de Mattos. Processo civil: teoria geral do processo e processo de conhecimento. Vol. 11, 3 ed. rev. São Paulo: Saraiva, 2000. p. 19.

${ }^{106}$ BRASIL. Constituição Federal. Disponível em: http://www.planalto.gov.br/ccivil_03/ Constituicao/Emendas. Acesso em: 02 out. 2008.
} 
[...] o juiz não é desvinculado da prova e dos elementos existentes nos autos (quod non est in actisnonest in mondo), mas a sua apreciação não depende de critérios legais determinados a priori. $\mathrm{O}$ juiz só decide com base nos elementos existentes no processo, mas os avalia segundo critérios críticos e racionais [...] O princípio do livre convencimento do juiz prende-se diretamente ao sistema da oralidade e especificamente a um de seus postulados, a imediação (infra, n. 209). ${ }^{107}$

Como visto acima, haveria uma associação entre os princípios da verdade formal e do livre convencimento motivado do julgador, este interligado também ao princípio da oralidade. A verdade obrigaria que o magistrado expressasse as razões de sua convicção.

[...] Esta submissão do pensamento jurídico à metodologia das ciências puramente lógicas, como a matemática, ou das ciências experimentais, suprimiu do horizonte do direito moderno - especialmente nos sistemas que provêm do direito romano-canônico - os juízos de verossimilhança de que, em direito romano (clássico), o praetor utilizava-se para a concessão da tutela interdital. ${ }^{108}$

\subsubsection{A verdade no processo civil: formal ou real?}

Do texto se conclui que o controle do convencimento do julgador teria relação, não apenas com as normas jurídicas, mas envolveria também, as ideologias e a concepção de mundo de cada julgador, as quais possam interferir no julgamento da causa, que é o mais próximo possível da verdade.

As definições relacionadas aos princípios: dispositivo, livre investigação da provas e persuasão racional do juiz, se consideram mais diretamente ligados

\footnotetext{
${ }^{107}$ CINTRA, Antônio Carlos de A., GRINOVER, Ada P., DINAMARCO, Cândido R. Teoria geral do processo. 22. ed. São Paulo: Malheiros, 2006. p. 74. (grifo do autor).

${ }^{108}[\ldots]$ rejeitar como falso tudo o que fosse apenas verossímil, aceitando como verdadeiro apenas aquilo que se apresentasse à nossa observação como alguma coisa 'tão clara e distinta que o espírito não tivesse a menor possibilidade de pô-la em dúvida ' [...]. In: SILVA, Ovídio Baptista da. Teoria geral do processo civil. 3. ed. rev. e atual. São Paulo: Editora Revista dos Tribunais, 2002. p. 57-58.
} 
à questão da verdade no processo. O princípio dispositivo é a prescrição de que o juiz depende "[...] da iniciativa das partes quanto às provas e às alegações em que se fundamentará a decisão: judex secundum allegata et probata partium iudicare debet.", na busca da imparcialidade do juiz.

A justificativa principal para a existência do princípio dispositivo (verdade formal) seria a necessidade do juiz se manter em uma atitude de distanciamento das partes e com isso garantir a realização do princípio da isonomia. ${ }^{110}$

Para alguns doutrinadores, o princípio teria “[...] bem demarcado o limite de atuação investigativa da autoridade judiciária, aos fatos alegados, às provas e ao pedido formulado.", não podendo a verdade processual surgir de outra forma.

Para outros doutrinadores, no entanto, a evolução dos princípios da verdade formal e da verdade real teria aproximado as duas concepções, já desgastadas pela aplicação às situações concretas do processo.

Nesse sentido, Luiz Flávio Gomes, observa que tantos foram os pontos em que se excepcionou o princípio da verdade real, que atualmente já não teria quase aplicação no processo penal, podendo já se falar em verdade processual penal ao invés da busca da verdade real. ${ }^{12}$

${ }^{109}$ CINTRA, Antônio Carlos de A., GRINOVER, Ada P., DINAMARCO, Cândido R. Teoria geral do processo. 22. ed. São Paulo: Malheiros, 2006. p. 70. (grifo do autor)

${ }^{110}$ Ibidem. p. 70. (grifo do autor)

${ }^{111}$ SCHLICHTING, Arno Melo. Teoria geral do processo: concreta, objetiva, atual. 2 ed. Florianópolis: Momento Atual, 2004. p. 54.

${ }^{112}$ [...] vigora no processo penal brasileiro a regra da liberdade de provas, isto é, todos os meios probatórios, em princípio, são válidos para comprovar a verdade real. [...] Diante de tantas exceções e restrições, melhor hoje é falar em princípio da verdade processual (que é a verdade produzida no processo e tão-somente a que nele pode ser concretizada). In: GOMES, Luiz Flávio (org). Direito processual penal. São Paulo: Editora Revista dos Tribunais: IELF, v. 6, 2005. p. 23-25. (grifos do autor) 
Segundo Fernando Capez, mesmo havendo o interesse público justificando a busca da verdade real, os atos promovidos pelos juízos somente existem em função do processo, sendo uma verdade formal e, não como parece, real. ${ }^{113}$

A doutrina majoritária, na teoria do processo, tende a adotar um posicionamento de "mitigação" do princípio da disponibilidade no processo civil, em comparação à livre investigação das provas no processo penal. Nessa linha há o pensamento de Rosemiro Pereira Leal, quanto à inexistência do princípio inquisitório.

[...] quando a lei determina que o juiz, por impulso oficial, provoque ex officio ato processual probatício, não age sob o que chamam de princípio inquisitório, porque só assim o seria se não existisse lei prévia determinadora da conduta jurisdicional. No Estado Democrático de Direito não há mais falar em princípio inquisitório, isto é, em referente lógico da atuação jurisdicional sem conteúdo legal. Quanto o juiz, secundum legis, toma a iniciativa probatória, seguindo o que os processualistas cognominam de princípio da verdade real, não está exercendo atividade inquisitória, [...] obediente à imperatividade legal da livre investigação da prova, ainda assim não pode, a seu talante, exceder-se aos limites de atuação jurisdicional, porque quebraria, como bem acentua Ovídio A. Baptista da Silva, a imparcialidade que é 'pressuposto lógico do próprio conceito de jurisdição'. ${ }^{114}$

Do que foi apresentado acima, se discute a atuação de ofício do magistrado conflitaria com a sua neutralidade, sendo que pelo princípio da livre investigação das provas, no processo penal, haveria uma flexibilidade a esse respeito.

No campo do processo civil, embora o juiz hoje não mais se limite a assistir inerte à produção das provas, pois em princípio pode e deve assumir a iniciativa destas (CPC; arts. 130, 342 etc.), na maioria dos casos (direitos disponíveis) pode satisfazer-se com a verdade formal, limitando-se a acolher o que as partes levam ao processo e eventualmente rejeitando a demanda ou a defesa por falta de elementos probatórios. No processo penal, porém, o fenômeno é inverso: só excepcionalmente o juiz penal se satisfaz com

${ }^{113}$ CAPEZ, Fernando. Curso de processo penal. 12. ed. rev. e atual. São Paulo: Saraiva, 2005. p. 22-23.

${ }^{114}$ LEAL, Rosemiro Pereira. Teoria geral do processo: primeiros estudos. 7.ed. rev.e atual. Rio de Janeiro: Forense, 2008. p. 114-115. (grifos do autor) 
a verdade formal, quando não disponha de meios para assegurar a verdade real (CPP, art. 386, inc. VI). ${ }^{115}$

Outro aspecto debatido é que o processo civil, na forma atual, estabeleceria em diferença entre convicção de verdade e juízos de verossimilhança, sendo provisórios e restritos às decisões interlocutórias (processo) e não aos juízos de mérito (causa).

[...] A supressão dos juízos de verossimilhança determinou, como é natural, o desaparecimento da retórica e da tópica aristotélicas, [...] de tal modo que a doutrina moderna, submetida às metodologias das ciências exatas, impede que o juiz profira julgamento com base em verdades apenas prováveis. Tudo o que o julgador disser sob forma de juízos provisórios, [...] é considerado como um 'não-juízo', e o provimento judicial tido como simples decisão sobre o processo, não sobre a lide. Daí o caráter de simples decisões interlocutórias que se dá a todos os provimentos judiciais que não sejam o último, com o qual se encerra a relação processual. ${ }^{116}$

Do texto acima, se depreende que como conseqüência da exclusão dos juízos de verossimilhança das decisões judiciais definitivas haveria, segundo esses autores, uma inversão da ética jurisdicional - do direito provável para o improvável - ensejando a realização da Justiça às avessas e, com isso, privilegiando uma das partes. ${ }^{117}$

Diante disso, percebe-se que a mitigação entre os princípios na verdade ocasionou, na prática, a supressão dos mesmos, por interferir na essência da distinção entre processo penal e processo civil. No caso, a natureza pública do processo penal não permite que se suponha a mera instrução processual como suficiente para a correta distribuição do poder jurisdicional do Estado.

E no processo civil, a busca da verdade real pelo juiz fica incompleta, pois somente tem iniciativa em situações isoladas, na forma já comentada em relação

\footnotetext{
${ }^{115}$ CINTRA, Antônio Carlos de A., GRINOVER, Ada P., DINAMARCO, Cândido R. Teoria geral do processo. 22. ed. São Paulo: Malheiros, 2006. p. 71. (grifo do autor)

${ }^{116}$ SILVA, Ovídio Baptista da. Teoria geral do processo civil. 3. ed. rev. e atual. São Paulo: Editora Revista dos Tribunais, 2002. p. 58.

${ }^{117}$ Ibidem.
} 
aos juízos de verossimilhança. Com isso, o magistrado, em qualquer um dos dois processos, somente atenderá à disposição constitucional da devida fundamentação da decisão judicial se não houver a mitigação exagerada desses princípios.

A esse respeito, comenta Adalberto Hommerding que "ainda se acredita numa 'teoria geral do processo', como se fosse possível unir ramos tão distintos, como são o processo penal e o processo civil, mesmo reconhecendo a diversidade de seu objeto.." ${ }^{118}$

Com isso, poderia se inviabilizar a aplicação dos referidos princípios, deixando antever uma atitude de cunho ideológico, a qual comprometeria o exercício dos direitos assegurados nas disposições constitucionais. ${ }^{119}$

Do que foi exposto neste ponto, conclui-se que a presença de princípios no processo civil serviria como uma forma de se garantir o atendimento a questões fundamentais sobre as quais não haveria discussão sobre a sua validade. Ocorre que mesmo a implementação prática dos princípios, desde a perspectiva hermenêutica, não seria imediata.

O processo de interpretação principiológica e mesmo a busca de esclarecimento sobre o sentido das normas jurídicas, implicaria muitas vezes em debates intermináveis. Além disso, como visto na abertura deste capítulo não se pode esquecer o papel exercido pelo senso comum e pelas questões da ideologia sobre a prática jurídica.

Embora esse tema seja abordado novamente no capítulo terceiro, tal fato não impede que se ressalve, desde já, a constatação que qualquer formulação da verdade como princípio não deve ser interpretada isoladamente, nem em relação

\footnotetext{
${ }^{118}$ HOMMERDING, Adalberto Narciso. Fundamentos para uma compreensão hermenêutica do processo civil. Porto Alegre: Livraria do Advogado, 2007. p. 112.

${ }^{119}$ Adalberto comenta: [...] Ora não há por que se falar em uma unificação do processo civil e do processo penal em uma teoria geral do processo. Enquanto, no âmbito do processo civil, há lide, no ramo do processo penal nem se há de falar nesse instituto. Mesmo a jurisdição penal diferencia-se da civil. Ibidem. p. 113.
} 
aos demais princípios, nem quanto ao contexto da prática jurídica e da função social do direito.

\subsection{A metodologia de trabalho com ênfase na linguagem}

Duas abordagens principais dão suporte à metodologia do trabalho: a questão da linguagem e a sua importância para o direito; e a definição do que seria a verdade para a filosofia e a consequência dessa definição no campo jurídico, sendo que a correlação entre essas análises será vista ao longo da exposição do presente item.

Quanto à definição sobre o que vem a ser a linguagem jurídica, os estudos a respeito do tema apontam para uma natureza complementar entre dois conceitos: a semiologia e a semiótica, não se esgotando em uma delas, sendo conhecidos três níveis de análise da linguagem jurídica escrita: lógico-lingüística, semântica e pragmática. ${ }^{120}$

Em relação ao estudo da linguagem jurídica, Leonel Rocha, na obra "Epistemologia jurídica e democracia", aponta pelo menos três correntes da semiótica jurídica, existindo uma tradição brasileira mais antiga, na interpretação das decisões judiciais.

[...] A semiótica do direito é quase inexistente no Brasil, já que os estudos jurídicos semióticos, teóricos ou aplicados, são raros no nosso meio. Somente há pouco tempo, a partir da década de setenta, é que se começou a falar sobre o assunto. Esta possibilidade de se realizar análises relativamente sistematizadas sobre os signos jurídicos foi provocada fundamentalmente por três tipos de influências: a) a Lógica Jurídica; b) a Nova Retórica; c) a Escola Analítica de Buenos Aires. [...] No Brasil, ainda que os estudos semióticos do direito sejam recentes, a questão da interpretação tem uma relativa tradição. Com efeito, existe uma conduta metodológica interpretativa dominante na

${ }^{120}$ ROBLES, Gregorio. O direito como texto: quatro estudos de teoria comunicacional do direito. Tradução de Roberto Barbosa Alves. Barueri, SP: Manole, 2005. p. 56. 
hermenêutica jurídica, voltada sobretudo para o problema da interpretação com vista à aplicação da lei pelos juízes. ${ }^{121}$

Do texto acima deve ser salientado o fato de já existir no direito brasileiro uma tradição de interpretação dos fenômenos jurídicos, o que pode ensejar dificuldades quanto à possibilidade de surgimento de novas formas de análise do contexto jurídico, sendo plausível a resistência a mudanças de natureza teórica.

Além do fato de já existir no direito brasileiro uma concepção arraigada sobre a forma de interpretação, as novas escolas surgidas com o objetivo de dar ênfase ao papel da linguagem também não obtiveram resultados satisfatórios, pois essas correntes de análise da linguagem apresentariam a deficiência metodológica de uma atuação de forma exclusivistas, excludentes e incompletas. ${ }^{122}$

A falta de um trabalho de cooperação interdisciplinar fez com essas escolas não tivessem resultados efetivos devido ao posicionamento tido "[...] como fundamentais e únicos, aspectos parciais do fenômeno jurídico. [...] Um tal projeto para produzir resultados positivos está ligado à tarefa de elaboração de um novo espaço teórico denominado Semiótica do Direito.", onde seriam complementares a

despeito do seu objeto. ${ }^{123}$

Por esse raciocínio, enquanto não houvesse um trabalho voltado para o estudo da linguagem em todos os seus aspectos, não haveria por parte do direito a produção de um conhecimento genuinamente novo sobre o assunto.

\footnotetext{
${ }^{121}$ ROCHA, Leonel Severo. Epistemologia jurídica e democracia. São Leopoldo: Ed. Unisinos, 1998. p. 24.

${ }^{122}$ ROCHA, Leonel Severo. Epistemologia jurídica e democracia. São Leopoldo: Ed. Unisinos, 1998. p. 19.

${ }^{123}$ Segundo Leonel Rocha: [...] A Semiótica divide-se tradicionalmente, segundo Carnap, em três partes: sintaxe, semântica e pragmática. A sintaxe possui como objeto a estrutura formal da linguagem (dos signos para alguns), por meio da análise lógico-linguística, a semântica visa averiguar o sentido das proposições, a partir das relações dos enunciados com a realidade e a pragmática, dirigida ao uso e às intenções das proferências discursivas. Ibidem. p. 20-21.
} 
Alguns doutrinadores entendem ser possível reconhecer três níveis de análise da linguagem jurídica escrita: análise lógico-linguística, análise semântica e análise pragmática, as quais, embora façam parte de um estudo da teoria jurídica, nos aspectos formal, dogmático e da decisão, podem ser aplicados à análise de texto.

[...] A respeito de todo texto abem análises dispares, que costumam ser agrupadas em três tipos: ou se estuda a estrutura da linguagem (análise lógico-lingüística), ou se estuda seu conteúdo de significado (análise semântica) ou, por último, se estuda o aspecto dinâmico de criação do texto (análise pragmática). [...] Nosso propósito é considerar, com maior extensão, que estes três níveis de análise também são possíveis em relação ao direito considerado como texto. ${ }^{124}$

Com relação ao estudo do conceito filosófico de verdade, cabe ressaltar o fato que a maioria das definições apresentadas tem por base as concepções teóricas da filosofia centrada na consciência individual e não em uma percepção coletiva consensual.

Além disso, nas definições apresentadas a seguir não há uma definição unívoca de verdade, estando presente idéias a esse respeito já na especulação dos filósofos gregos na antiguidade, podendo ser distinguidas três fases nas especulações sobre a verdade: a dialética, a do ser e a da subjetividade.

A verdade dialética em Heráclito de Éfeso é que o mundo está em eterno movimento, evidenciado pelo confronto entre oposto e que em Deus há a síntese dos contrários, sendo a divindade a origem, portanto, de toda harmonia. ${ }^{125}$

Se para Heráclito a verdade é Deus, no pensamento de Parmênides de Eléia a verdade é o princípio mais importante, onde ser e pensar são equivalentes, não

${ }^{124}$ ROBLES, Gregorio. O direito como texto: quatro estudos de teoria comunicacional do direito. Tradução de Roberto Barbosa Alves. Barueri, SP: Manole, 2005. p. 56.

125 [...] se o devir é dado pelos opostos que se contrastam e, contrastando-se pacificam-se em superior harmonia, então é claro que na síntese de opostos está o princípio que explica toda a realidade, e é evidente, por conseqüência, que exatamente nisso consiste Deus ou o Divino. In: REALE, Giovanni. História da filosofia antiga”. Tradução de Marcelo Perine. São Paulo: Loyola, 1993. p. 66-69. (grifos do autor) 
havendo pensamento que não se originasse do ser e nem ser que não tenha sido pensado. $^{126}$

Com o sofista Protágoras de Abdera, a verdade passa de princípio universal a realidade individual, tendo o homem como o centro do conhecimento ao "[...] negar a existência de um critério absoluto que discriminasse o ser e o não-ser, o verdadeiro e o falso e, em geral, todos os valores: o critério é apenas relativo, é o homem, o homem individual.". 127

De Protágoras, onde a verdade é relativa, inerente a cada homem, os sofistas passam ao niilismo de Górgias de Leontina, onde a existência do ser é negada e, portanto, nada havendo a especular da verdade, pois ela inexistindo, não tem como

ser conhecida. ${ }^{128}$

Em Platão, há uma dualidade em conflito: a verdade como desencobrimento e como correção, prevalecendo a segunda, abandonada a sua correspondência com a vida: a verdade independe dos atos humanos e dos sentidos, originando-se no plano das idéias. ${ }^{129}$

Para Aristóteles a ciência é o conhecer verdadeiro ${ }^{130}$, implicando que a vinculação filosofia - verdade seja total, pois “[...] ela visa simplesmente à busca da

\footnotetext{
126“[...] qualquer pensar, para ser tal, é pensar o ser, a ponto de podermos dizer que pensar e ser coincidem, no sentido de que não há pensamento que não exprima o ser”. Ibidem. p. 107-109. (grifos do autor)

${ }^{127}$ Ibidem. p. 206. (grifos do autor)

${ }^{128}$ Ibidem. p. 211-215.

${ }^{129}$ Segundo Heidegger: “[...] por motivos essenciais, obteve a primazia a verdade como adequação do pensamento e da visão. [...] Desde Platão prevalece a determinação da verdade como propriedade da sentença.” In: HEIDEGGER, Martin. Ser e verdade: a questão fundamental da filosofia; da essência da verdade. Tradução Emmanuel Carneiro Leão. Petrópolis: Vozes, 2007. p. 229.

${ }^{130}$ Maria Lúcia comenta: “[...] se preocupa em definir a ciência como conhecimento verdadeiro, conhecimento pelas causas, capaz de superar os enganos da opinião e de compreender a natureza do devir". In: ARANHA, Maria Lúcia de A. Filosofando: introdução à filosofia. 2a . ed. rev. atual. São Paulo: Moderna, 1993. p. 97.
} 
verdade por si mesma; ela é, pois, 'livre' enquanto não se submete a qualquer utilização pragmática e, portanto, realiza-se e se resume em pura contemplação do verdadeiro.." ${ }^{131}$

As diversas formas de análise da verdade sofreram uma contínua reelaboração, até chegar à análise semântica, baseada no estudo dos significados das expressões afirmativas ou negativas da verdade. Porém, em oposição à abordagem lógica, há análises das teorias da verdade pela pragmática, preenchendo a lacuna de interpretação do sentido, das palavras até as intenções do discurso. ${ }^{132}$

Em relação às pesquisas lógicas sobre a verdade, cabe referência à teoria semântica da verdade, na perspectiva preconizada por Alfred Tarski e seus continuadores, pela qual se chega a conclusão que a verdade, do ponto de vista lógico-semântico, não poderia ser demonstrada universalmente. ${ }^{133}$

Assim, os enunciados criados visando ao atendimento de forma isolada de cada predicado examinado, seriam critérios utilizáveis apenas em relação a linguagens artificiais, cujo tamanho fosse limitado, não seriam aplicáveis às linguagens naturais. ${ }^{134}$

[...] as condições necessárias e suficientes para um objeto satisfazer uma dada sentença aberta são diferentes das

\footnotetext{
${ }^{131}$ REALE, Giovanni. História da filosofia antiga. Tradução Marcelo Perine. São Paulo: Loyola, 1993. p. 29.

${ }^{132}$ [...] Se a transpusermos do quadro de referência intrapsíquico para o interpessoal, a descrição freudiana do Id converte-se, virtualmente, numa definição de comunicação analógica: As leis da lógica [...] não são válidas para os processos do id. In: WATZLAWICK, Paul; BEAVIN, Janet Helmick; JACKSON, Don D. Pragmática da comunicação humana: um estudo dos padrões, patologias e paradoxos da interação. Tradução de Álvaro Cabral. 15. ed. São Paulo: Cultrix, 2005. p. 60-61.

${ }^{133}$ KIRKHAM, Richard L. Teorias da Verdade: uma introdução crítica. Tradução de Alessandro Zir. São Leopoldo: Editora Unisinos, 2003. p. 65.

${ }^{134}$ [...] O predicado de verdade pertence - embora não exclusivamente - ao jogo de linguagem da argumentação; por isso seu significado pode ser elucidado - ao menos também - segundo os critérios de suas funções nesse jogo de linguagem, ou seja, na dimensão pragmática de determinado emprego do predicado. In: HABERMAS, Jürgen. Verdade e justificação: ensaios filosóficos. Tradução de Milton Camargo Mota. São Paulo: Loyola, 2004. p. 248-249.
} 
condições necessárias e suficientes para que esse objeto satisfaça qualquer outra sentença aberta. [...] do fato de que a definição de satisfação deve ter uma cláusula separada para cada predicado na linguagem é que o método de Tarski só funciona para linguagens com um número finito de predicados. [...] Isso não é problema para as linguagens da matemática, que são as linguagens que interessam a Tarski, mas as linguagens naturais têm um número infinito de predicados. ${ }^{135}$

Deste modo, não haveria uma verdade, ensejando que o conhecimento jurídico, participando dessa natureza incompleta do conhecimento, não poderia buscar esse tipo de fundamentação no contexto filosófico, implicando assim que qualquer interpretação jurisprudencial esteja sujeita a revisão de seus pressupostos, a qualquer tempo, com base nas formulações lógico-semânticas da impossibilidade da existência de uma verdade universal.

Outro aspecto, além da concepção parcial da natureza de verdade, seria a necessidade de referenciais teóricos em que houvesse a compreensão sobre a crise epistemológica e de autocrítica da filosofia, sobretudo abordando a proposta de superação da chamada filosofia da consciência pela adoção da filosofia na perspectiva da linguagem. ${ }^{136}$

Logo, a escolha recaiu sobre a hermenêutica filosófica e a pragmática universal, que têm em comum a tentativa de rompimento com a chamada filosofia da consciência, cuja idéia seria que o pensamento racional do homem a respeito do mundo prevalece sobre o real (metafísica).

As duas concepções são focadas no fenômeno da linguagem, na realização de uma mudança no conceber a filosofia: o giro lingüístico, presente, ainda que implicitamente em formulações teóricas de diversos autores, desde textos da antigüidade até os autores do século XX. ${ }^{137}$

\footnotetext{
${ }^{135}$ Ibidem. p. 226-227. 229.

${ }^{136}$ STRECK, Lênio Luiz. Hermenêutica jurídica e(m) crise: uma exploração hermenêutica da construção do direito. 7. ed. rev. atual. Porto Alegre: Livraria do Advogado, 2007. p. 176.

${ }^{137}$ STRECK, Lênio Luiz. Hermenêutica jurídica e(m) crise: uma exploração hermenêutica da construção do direito. 7. ed. rev. atual. Porto Alegre: Livraria do Advogado, 2007. p. 119.
} 
Ambas colocam em primeiro plano a linguagem, como condição de existência do próprio filosofar; dando ênfase ao problema das relações de implicação entre discurso e realidade; e da desmitificação da interpretação separada da aplicação do texto. ${ }^{138}$

O questionamento da perspectiva filosófica centrada na razão e na individualidade estaria associado a mudanças em várias áreas do conhecimento, no século XX, privilegiando a interação social pela linguagem, ao invés da razão individual (filosofia da consciência), movimento conhecido como reviravolta lingüística ou giro lingüístico.

\subsubsection{A reviravolta linguística da filosofia como novo ponto de partida}

Para compreensão dessa ruptura epistemológica no pensamento filosófico é necessário recorrer-se ao estudo da reviravolta lingüística ou "giro lingüístico", cuja distinção essencial seria a linguagem como modo de compreensão do comportamento no mundo.

\footnotetext{
${ }^{138}$ Ibidem. p. 182-183. ${ }^{139}$ Ibidem. p. 143.
}

[...] esboçada por Giambatista Vico, desenvolvida, porém, por Johann Georg Hamann, Johan Gottfried Herder e Wilhelm von Humboldt. Tão importantes são tais autores que Cristina Lafont os coloca como precursores do rompimento com o paradigma instituído pela filosofia da consciência. Ou seja, no paradigma da filosofia da consciência a concepção vigente é a de que a linguagem é um instrumento para a designação de entidades independentes desta ou para a transmissão de pensamentos pré-lingüísticos, concebidos sem a intervenção da linguagem. Assim, somente depois de superar esse paradigma, mediante o reconhecimento de que a linguagem tem um papel constitutivo na nossa relação com o mundo é que se pode falar em uma mudança paradigmática, representado pelo rompimento com a filosofia da consciência pela filosofia da linguagem. ${ }^{139}$ 
Infere-se que a superação da filosofia da consciência se dá com o reconhecimento de um novo conceito para a linguagem, não como meio de comunicação apenas, mas como condição e limite das formas de expressar e de existir no mundo, mudança que teria relação com os estudos do "Círculo de Viena".

Concomitantemente ao giro lingüístico, teriam ocorrido os giros ontológico, hermenêutico e pragmático, levando a um processo de revisão do conceito de verdade, aqui estudado de forma preliminar, em sua importância para o direito em relação a linguagem, importando ressaltar sua validade como procedimento metodológico, na presente monografia, em que a primeira perspectiva de análise é do ponto de vista jurídico, enquanto a segunda é em uma nova perspectiva, de cunho filosófico baseada na linguagem.

\subsubsection{A hermenêutica jurídica fundamentada na hermenêutica filosófica}

Com base na epistemologia da ciência, os conceitos de base adotados na pesquisa foram os seguintes: desdogmatização, desconstrução das teorias, as rupturas epistemológicas e o círculo hermenêutico. ${ }^{141}$

A Desdogmatização seria o estabelecimento da dúvida de forma sistemática, supondo qualquer conhecimento como falível, sujeito a limitações e merecedor de análise das condições de sua aplicação, buscando estabelecer os seus limites e as conseqüências práticas da sua aplicação na ${ }^{\text {sociedade }}{ }^{142}$

\footnotetext{
${ }^{140}[. .$.$] Os positivistas lógicos sustentavam a idéia de que o conhecimento pode ser$ obscurecido por certas perplexidades de natureza estritamente lingüística. Desse modo, reduzindo a filosofia à epistemologia, e esta à semiótica, afirmam que a missão mais importante da filosofia deve realizar-se à margem das especulações metafísicas, [...] $\mathrm{O}$ rigor discursivo passa a ser o paradigma de ciência; sem rigor lingüístico não há ciência; fazer ciência é traduzir numa linguagem rigorosa os dados do mundo. In: STRECK, Lênio Luiz. Hermenêutica jurídica e $(\mathrm{m})$ crise: uma exploração hermenêutica da construção do direito. 7. ed. rev. atual. Porto Alegre: Livraria do Advogado, 2007. p. 165.

${ }^{141}$ SANTOS, Boaventura de S. Introdução a uma ciência pós-moderna. Rio de Janeiro: Graal, 1989. p. 22.

${ }^{142}$ Ibidem. p. 23.
} 
Para os fins da presente monografia, o conceito de "ruptura epistemológica" seria um sinônimo do conceito de "corte epistemológico", pelo qual haveria uma delimitação do objeto de estudo, de modo a facilitar a compreensão dos fenômenos que ali ocorrem, evitando desse modo uma atitude de pesquisa superficial e generalizadora. $^{143}$

Por outro lado, a ruptura epistemológica propicia o atendimento aos aspectos da análise dos resultados da pesquisa e a necessidade da autocrítica dos resultados alcançados, sendo o momento de definição do escopo da análise pretendida.

Esses conceitos (desdogmatização e ruptura epistemológica) comporiam o círculo hermenêutico, no qual a definição, aplicação e revisão das teorias adotadas teriam estabelecidas suas limitações e as influências do pesquisador sobre o objeto pesquisado.

[...] O círculo hermenêutico cumpre-se, desconstruindo um a um os diferentes objetos teóricos que a ciência constrói sobre si própria e, com eles, as diferentes imagens que dá de si, a fim de tornar compreensível por que razão foram construídos esses objetos e não outros [...] A desconstrução faz-se mediante o apelo ao inobjetivável e ao inimaginável que tornam ou tornaram socialmente possíveis os objetos e as imagens científicas em uso. ${ }^{145}$

Como visto no texto acima, o círculo hermenêutico seria o conceito fundamental da hermenêutica filosófica, para os fins do presente trabalho, ao estabelecer que a observação deve ser recebida pelo pesquisador, a qual deve responder com as suas convicções, reformulando e aperfeiçoando o conhecimento até então realizado, para receber de volta as impressões do objeto de pesquisa em um movimento contínuo de aprimoramento da percepção.

${ }^{143}[. .$.$] tratar o fenômeno jurídico somente sob uma de suas dimensões, desde que, porém,$ não se esqueça de que o corte epistemológico que tal atitude representa não envolve uma exclusão dos outros aspectos da juridicidade. Há mesmo ramos da Ciência que se especializam em cada um deles. In: MELLO, Marcos Bernardes de. Teoria do fato jurídico: plano da existência. 11. ed. São Paulo: Saraiva, 2001. p. 18.

${ }^{144}$ SANTOS, Boaventura de S. Introdução a uma ciência pós-moderna. Rio de Janeiro: Graal, 1989. p. 147.

${ }^{145}$ Ibidem. p. 13. 
Como síntese dessa concepção filosófica e, como forma de fazer uso dos conceitos do senso comum, sua definição poderia pode ser sintetizada na forma de uma comparação alegórica com um objeto do mundo material, no caso um Iceberg, como será visto a seguir.

Um Iceberg é uma porção de gelo a qual grande parte está submersa, deixando aos que observam uma idéia errônea acerca de suas reais dimensões, como se costuma dizer: "A ponta do Iceberg". Tal situação poderia ser comparada ao estudo de um objeto pelo pesquisador nas ciências sociais, o qual, no momento que tem contato com seu objeto de estudo, tem a idéia que seu tamanho real é exatamente aquele que já antecipadamente mensurou, ignorando que a maior parte de seu objeto de estudo ainda é desconhecida.

Além disso, o grande perigo do Iceberg é a sua aproximação repentina, a qual toma de surpresa as embarcações que não têm idéia da sua dimensão e costumeiramente são danificadas com o impacto do choque com o Iceberg. Esse acontecimento seria análogo ao pesquisador que se satisfaz com o conhecimento adquirido em suas pré-noções do seu objeto de pesquisa, as quais podem ensejar a perda com contato com a realidade observada, impedindo o conhecimento do contexto da pesquisa e dos reais problemas encontrados.

A figura do Iceberg enseja também uma perspectiva de análise quanto ao fato que o pesquisador somente pode conhecer de fato seu objeto de pesquisa estando próximo a ele, mensurando-o, ao invés de se contentar com o contato a distância, visual e superficial que permite alguns tipos de especulação, mas que não permite uma fusão entre o horizonte do pesquisador e os limites reais do seu objeto.

Ao momento que o pesquisador tiver consciência da necessidade de realização desses passos em busca do conhecimento do Iceberg, superando o conflito intelectual entre a situação pensada e a situação da existência, terá conseguido realizar o círculo ou espiral hermenêutica necessária na interpretação do fenômeno estudado. 


\subsubsection{A pragmática universal na análise do discurso jurídico}

O conceito fundamental é a situação ideal de fala, como um espaço discursivo onde os participantes têm interesse em apresentar e ouvir os argumentos sem recursos a pré-noções ou conceitos, permitindo-se reavaliar os seus pontos de vista em busca de um consenso. Maria Cândida Souza define como Habermas elabora o conceito acima.

A 'situação ideal de fala', através da qual deve se desenvolver a práxis discursiva constitui a circunstância especial que proporciona a imparcialidade, porquanto os interlocutores, por estarem interessados em participar do processo argumentativo, seriam tendentes a um acordo racionalmente motivado, transmudado a reflexão moral em um procedimento discursivo, que previamente estabeleça as regras de participação, e, ao qual, todos concordem em se submeter, de modo a que possam interagir argumentativamente. ${ }^{146}$

Conforme apresentado acima, o pressuposto da situação ideal de fala seria um comportamento ético generalizado de participação ativa, aliado ao respeito pelos posicionamentos divergentes, sem a existência de uma estratégia a sobrepujar o outro numa relação vantajosa desigual.

Na tentativa de expor de uma forma mais detalhada o conteúdo dessa concepção, cabe o recurso também a uma alegoria do mundo do senso comum, no caso a situação de um jogo idealizado de cartas. Nesse jogo, os parceiros saberiam antecipadamente as cartas que cada um possui e nenhum jogador pode ter a atitude de ocultar uma "Carta na Manga" ou "Blefar".

Assim é a situação ideal de fala em que o compromisso ético dos participantes enseja que não dissimulem suas intenções, não devendo agir de forma estratégia, visando sobrepujar o companheiro ou no intuito de adquirir alguma vantagem pessoal.

\footnotetext{
${ }^{146}$ SOUZA, Maria Cândida Gomes de. O espaço público judicial: a participação do judiciário na esfera democrática pela via da ação comunicativa. Orientadora: Giselle Cittadino. Rio de Janeiro: PUC, Departamento de Direito, 2005. p. 18-68.
} 
O jogo de cartas seria realizado carta a carta, devendo os participantes intervir quando considerarem necessário, da mesma forma que em uma situação ideal de fala, na qual há o compromisso de todos com a busca da solução.

Além disso, esse jogo idealizado permitiria que novos jogadores se juntassem à partida, como no agir comunicativo, no qual o número de interlocutores é infinito, dependendo apenas da deliberação de cada um em realizar sua participação.

Nesse jogo, haveria o compromisso que tudo o que fosse motivo de acordo entre os parceiros, seria respeitado durante e depois da partida, da mesma forma que na situação ideal de fala em que a consciência moral de cada um é a condição do seu agir comunicativo. Logo, não haveria ganhador/perdedor, mas interlocutores e debatedores, reconhecidos por todos os argumentos racionalmente apresentados, superando o solipsismo da opinião individual que daria lugar ao consenso livremente buscado, sem estratégias para derrotar um oponente.

Por fim, esse jogo de cartas pressupõe uma linha comum e compreensível a todos, havendo o compromisso de cada um de manter respeito pelo outro em sua individualidade, procurando entendê-lo, assim como na situação do agir comunicativo, focado na importância da linguagem para a realização conjunta da individualidade e da intersubjetividade.

\subsection{As técnicas de pesquisa na interpretação legal e jurisprudencial}

A primeira técnica utilizada é o recurso ao senso comum como forma de ilustração das teorias estudadas, como forma didática de apresentação dos conhecimentos adquiridos, conforme foi visto na introdução deste capítulo. Além disso, em relação ao exame da Súmula do Superior Tribunal de Justiça - STJ, houve a utilização do conceito de postulados normativos aplicados, conforme indicado no Subitem 2.1 deste capítulo. 
Assim, a técnica de pesquisa utilizada na análise dos enunciados dos capítulos 1 e 3 foi a investigação do inteiro teor dos julgados pesquisados, seguindo às seguintes diretrizes.

a) Investigar a jurisprudência dos tribunais superiores, em busca de decisões que tenham mencionado a utilização de postulados normativos;

b) Obter a íntegra dos acórdãos em que são mencionados os referidos postulados;

c) Analisar as decisões e verificar os elementos ou grandezas que foram manipulados;

d) Verificar quais as relações consideradas essenciais entre eles;

e) Quanto às normas objeto de aplicação, verificar os elementos ou grandezas que foram manipulados;

f) Encontrar os motivos que levaram os julgadores a entender existentes ou inexistentes determinadas relações entre eles;

g) Verificação de outros casos que deveriam ter sido decididos com base em postulado; $\mathrm{e}$

h) Analisar criticamente as decisões encontradas, reconstruindoas argumentativamente de acordo com o postulado em exame, evidenciado a falta do seu uso.

Por último, cabe informar sobre a pesquisa exploratória com a coleta de dados eletrônicos (via Internet), relativamente à legislação federal (Presidência da República e Senado Federal) e ao Supremo Tribunal Federal - STF e Superior Tribunal de Justiça - STJ.

No que respeita à coleta de dados da jurisprudência, o procedimento adotado foi a busca no "Portal do STJ" (Internet), utilizando o critério de seleção do tipo de decisão (acórdãos e decisões monocráticas), e indicação das expressões "súmula" e "resp"."147

${ }^{147}$ SUPERIOR TRIBUNAL DE JUSTIÇA. Disponível em: http://www.stj.jus.br/SCON/ pesquisar.jsp. Acesso em: 15 out. 2008. 
O resultado foi a seleção de 1.483 .130 (um milhão e quatrocentos e oitenta e três mil e cento e trinta) documentos e o levantamento amostral nesse acervo procurou verificar a proporção dos acórdãos publicados em que a fundamentação foi em "súmula".

TABELA 1 - PESQUISA NA BASE DE DADOS DA JURISPRUDÊNCIA DO STJ NÚMERO DE JULGADOS COM FUNDAMENTO EM SÚMULAS SOBRE RECURSO ESPECIAL

\begin{tabular}{|c|c|c|c|c|}
\hline ENUNCIADO & SÚMULAS & ACÓRDÃOS & DECISÕES MONOCRÁTICAS & TOTAL \\
\hline 5 & 2 & 34026 & 581098 & 615.126 \\
\hline 7 & 1 & 19249 & 466561 & 485.811 \\
\hline 13 & 1 & 3478 & 191620 & 195.099 \\
\hline 83 & 1 & 1912 & 64844 & 66.757 \\
\hline 86 & 1 & 1289 & 16387 & 17.677 \\
\hline 123 & 1 & 205 & 8179 & 8.385 \\
\hline 126 & 1 & 1149 & 25343 & 26.493 \\
\hline 203 & 1 & 560 & 12737 & 13.298 \\
\hline 207 & 1 & 339 & 6852 & 7.192 \\
\hline 211 & 1 & 1998 & 39033 & 41.032 \\
\hline 315 & 2 & 104 & 2368 & 2.474 \\
\hline 316 & 1 & 84 & 3701 & 3.786 \\
\hline TOTAIS & 14 & 64.393 & 1.418 .723 & 1.483 .130 \\
\hline
\end{tabular}

Fonte: Jurisprudência do Superior Tribunal de Justiça ${ }^{148}$

Quanto à forma de aplicação das súmulas, nota-se que uma proporção dos julgamentos acontece na forma de decisões monocráticas, nas quais exclusivamente o relator aprecia o pedido e encerra a questão, sem apreciação pelos órgãos colegiados do tribunal.

O gráfico a seguir apresenta a proporção entre os enunciados da súmula tratando do cabimento dos recursos especiais, com base no total de documentos apurado, na forma que foi apresentada na Tabela 1 , já referida.

\footnotetext{
${ }^{148}$ SUPERIOR TRIBUNAL DE JUSTIÇA. Disponível em: http://www.stj.jus.br/SCON/ pesquisar.jsp. Acesso em: 15 out. 2008.
} 


\section{GRÁFICO 1}

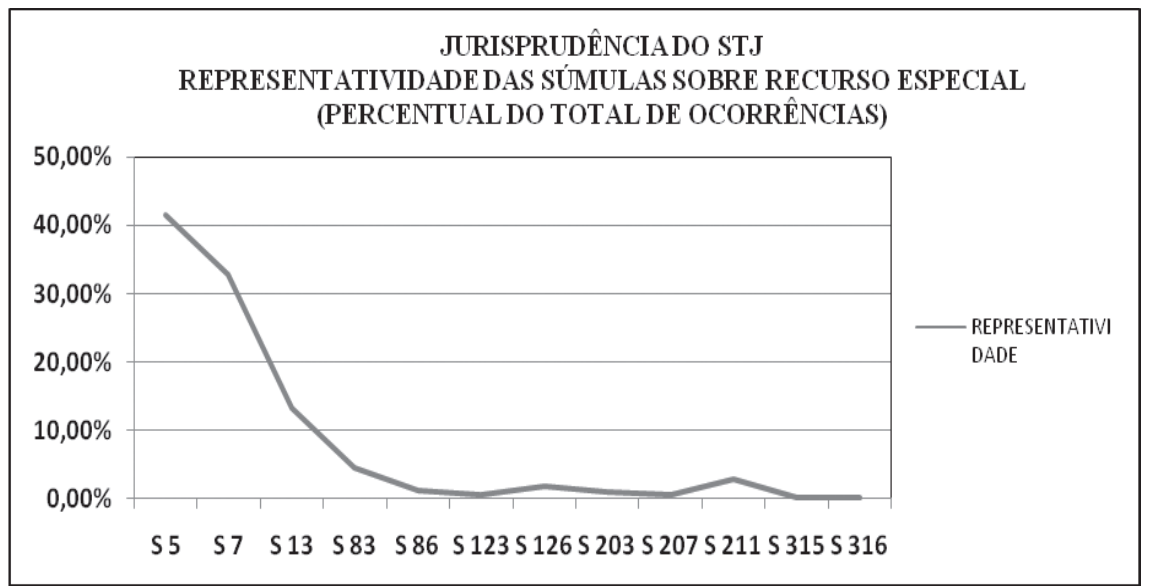

Fonte: Jurisprudência do Superior Tribunal de Justiça ${ }^{149}$

Conforme apresentado no gráfico acima, os enunciados de números 5 e 7 totalizam 75\% (setenta e cinco por cento) dos julgados e tratam da questão do exame de fatos e circunstâncias relativos aos autos, na instância ordinária, do que dá exemplo o texto do enunciado n. ${ }^{\circ}$ 5: "A simples interpretação de cláusula contratual não enseja recurso especial."

Em relação à forma de aplicação das súmulas, nota-se que uma proporção dos julgamentos acontece na forma de decisões monocráticas, nas quais exclusivamente o relator aprecia o pedido e encerra a questão, sem apreciação pelos órgãos colegiados, sendo que há cada vez maior de julgados tendo por referência os enunciados da súmula.

Sem estabelecer um tratamento diferenciado para as formas de decisão existentes, a busca pelas expressões "reexame" e "resp", tendo como critério de filtragem a opção "Súmula do Superior Tribunal de Justiça", é apresentada no gráfico a seguir, identificando a proporção de julgados que tiveram fundamento em Súmula do STJ.

${ }^{149}$ SUPERIOR TRIBUNAL DE JUSTIÇA. Disponível em: http://www.stj.jus.br/SCON/ pesquisar.jsp. Acesso em: 02 abr. 09. 
GRÁFICO 2 - PROPORÇÃO DE ACÓRDÃOS DO STJ COM BASE LEGAL EM SÚMULA CUJO TEMA SEJA RESP OU REEXAME

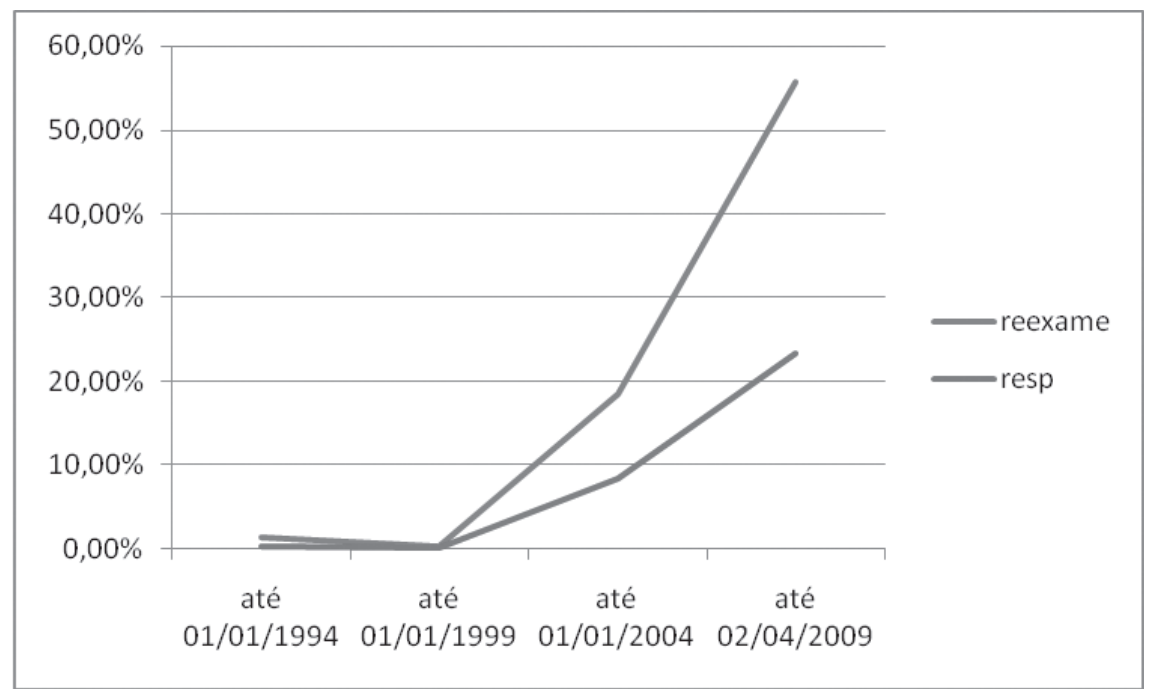

Fonte: Jurisprudência do Superior Tribunal de Justiçą ${ }^{150}$

Observa-se do gráfico acima, que as proporções Súmula/Resp e Súmula/ Reexame variaram de zero a $56 \%$ e $23 \%$, respectivamente, com expressivo crescimento nominal entre 1989 e 2009. Contudo, tal crescimento sofreu desaceleração mais recente, com tendência à estabilização das taxas de crescimento. Conforme se observa nos qüinqüênios apresentados no gráfico a seguir, a tendência do período de 1999 a 2004, não é representativa de todo o período, embora a taxa média da série sofra sua influência. ${ }^{151}$

\footnotetext{
${ }^{150}$ SUPERIOR TRIBUNAL DE JUSTIÇA. Disponível em: http://www.stj.jus.br/SCON/ pesquisar.jsp. Acesso em: 02 abr. 09.

${ }^{151}$ A pesquisa pelas expressões "resp" e "reexame", combinou a seleção do campo "legislação", ora com escolha de todas as normas ora apenas pela indicação das "Súmulas do Superior Tribunal de Justiça”, sendo observado que o período de maior proporção Súmula/Julgados, foi entre 2004 a 2009.
} 
GRÁFICO 3 - TAXA DE VARIAÇÃO DOS JULGADOS BASEADOS EM SÚMULAS

\begin{tabular}{|c|c|}
\hline $\begin{array}{l}\text { Súmula 5, DJ 21/05/1990, p. } \\
4407\end{array}$ & $\begin{array}{l}\text { A simples interpretação de cláusula contratual não } \\
\text { enseja recurso especial }\end{array}$ \\
\hline $\begin{array}{l}\text { Súmula } 7, \text { DJ 03/07/1990, p. } \\
6478\end{array}$ & $\begin{array}{l}\text { A pretensão de simples reexame de prova não } \\
\text { enseja recurso especial }\end{array}$ \\
\hline $\begin{array}{l}\text { Súmula } 13, \text { DJ } 14 / 11 / 1990, \\
\text { p. } 13025\end{array}$ & $\begin{array}{l}\text { A divergência entre julgados do mesmo tribunal } \\
\text { não enseja recurso especial }\end{array}$ \\
\hline $\begin{array}{l}\text { Súmula } 83, \text { DJ 02/07/1993, } \\
\text { p. } 13283\end{array}$ & $\begin{array}{l}\text { Não se conhece do recurso especial pela } \\
\text { divergência, quando a orientação do tribunal se } \\
\text { firmou no mesmo sentido da decisão recorrida }\end{array}$ \\
\hline $\begin{array}{l}\text { Súmula 86, DJ 02/07/1993, } \\
\text { p. } 13283\end{array}$ & $\begin{array}{l}\text { Cabe recı } \\
\text { julgamen }\end{array}$ \\
\hline $\begin{array}{l}\text { Súmula 123, DJ 09/12/1994, } \\
\text { p. } 34142\end{array}$ & $\begin{array}{l}\text { A decisão que admite, ou não, o recurso especial } \\
\text { deve ser fundamentada, com o exame dos seus } \\
\text { pressupostos gerais e constitucionais }\end{array}$ \\
\hline $\begin{array}{l}\text { Súmula 126, DJ 21/03/1995, } \\
\text { p. } 6369\end{array}$ & $\begin{array}{l}\text { É inadmissível recurso especial, quando o acórdão } \\
\text { recorrido assenta em fundamentos constitucional } \\
\text { e infraconstitucional, qualquer deles suficiente, por } \\
\text { si só, para mantê-lo, e a parte vencida não manifesta } \\
\text { recurso extraordinário. }\end{array}$ \\
\hline $\begin{array}{l}\text { Súmula 203, DJ 03/06/2002, } \\
\text { p. } 269\end{array}$ & $\begin{array}{l}\text { Não cabe recurso especial contra decisão proferida } \\
\text { por órgão de segundo grau dos Juizados Especiais }\end{array}$ \\
\hline $\begin{array}{l}\text { Súmula 207, DJ 16/04/1998, } \\
\text { p. } 44\end{array}$ & $\begin{array}{l}\text { É inadmissível recurso especial quando cabíveis } \\
\text { embargos infringentes contra o acórdão proferido } \\
\text { no tribunal de origem }\end{array}$ \\
\hline $\begin{array}{l}\text { Súmula 211, DJ 03/08/1998, } \\
\text { p. } 366\end{array}$ & $\begin{array}{l}\text { Inadmissível recurso especial quanto à questão que, } \\
\text { a despeito da oposição de embargos declaratórios, } \\
\text { não foi apreciada pelo tribunal a quo }\end{array}$ \\
\hline $\begin{array}{l}\text { Súmula } 315, \text { DJ } 18 / 10 / 2005, \\
\text { p. } 102\end{array}$ & $\begin{array}{l}\text { Não cabem embargos de divergência no âmbito } \\
\text { de agravo de instrumento que não admite recurso } \\
\text { especial }\end{array}$ \\
\hline $\begin{array}{l}\text { Súmula } 316, \text { DJ 18/10/2005, } \\
\text { p. } 103\end{array}$ & $\begin{array}{l}\text { Cabem embargos de divergência contra acórdão } \\
\text { que, em agravo regimental, decide recurso especial }\end{array}$ \\
\hline
\end{tabular}

Fonte: Jurisprudência do Superior Tribunal de Justiça ${ }^{152}$

${ }^{152}$ SUPERIOR TRIBUNAL DE JUSTIÇA. Disponível em: http://www.stj.jus.br/SCON/ pesquisar.jsp. Acesso em: 02/04/2009. 
Conforme visto no gráfico acima, embora se verifique um menor crescimento entre 2004 e 2009, ainda assim é significativa a variação do qüinqüênio: $302 \%$ (trezentos e dois por cento) na Súmula/Resp, face ao qüinqüênio anterior (1999-2004), e 276\% (duzentos e setenta e seis por cento) na Súmula/Reexame, mesmo período.

Em relação ao objeto dos enunciados à Súmula do STJ, a pesquisa exploratória revelou que dos 367 (trezentos e sessenta e sete) enunciados, em 12 (doze) deles o tema diz respeito à cabimento de recursos especiais ou em relação a outros critérios visando o seu conhecimento, apreciação e julgamento, conforme o quadro a seguir.

QUADRO 1 - SÚMULAS DO STJ TRATANDO DO CABIMENTO DE RECURSOS ESPECIAIS

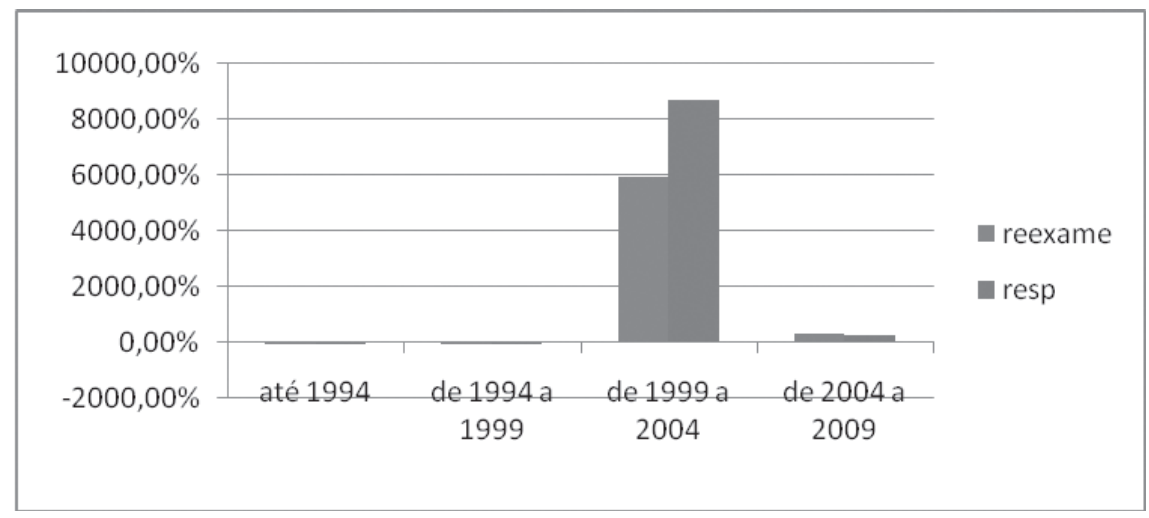

FONTE: Superior Tribunal de Justiça. ${ }^{153}$

Do quadro acima se verifica que os enunciados 5 e 7 têm fundamento em institutos assemelhados: a revisão de contratos pelo reexame de cláusulas (Enunciado n. ${ }^{\circ}$ ) e o reexame de provas de forma genérica (Enunciado n. ${ }^{\circ} 7$ ), a despeito do problema da auto-referência à Súmula do STJ e do eventual impacto na formação do convencimento dos operadores jurídicos.

${ }^{153}$ SUPERIOR TRIBUNAL DE JUSTIÇA. Disponível em: http://www.stj.jus.br/SCON/ pesquisar.jsp. Acesso em: 02/04/2009. 
A pesquisa histórica revelou um itinerário peculiar em três estágios e que no primeiro teria ocorrido a importação de princípio processual de tradição européia. ${ }^{154}$

No segundo momento, essa prática, recepcionada como norma de direito interno, foi incorporada ao ordenamento jurídico nacional pelo art. 231 do Regulamento do Código Comercial (Decreto n. ${ }^{\circ} 737$, de 25/11/1850), orientando o juiz, ao atender no todo ou em parte ao pedido inicial, estar motivado a agir "segundo for provado nos autos". 155

Também é oportuno mencionar que outros dispositivos legais reafirmaram o brocardo jurídico aludido, inclusive no atual Código de Processo Civil, na forma prevista no art. 131, o qual será devidamente analisado na exposição do Capítulo $3 .^{156}$

E no terceiro momento, o seu uso continuado na legislação, fez com que o brocardo internalizasse no senso comum dos juristas, servindo de referência à linguagem como critério do grau de cultura processual, fato que direcionou a pesquisa para uma abordagem interdisciplinar do conceito jurídico de verdade formal e a valoração da prova.

\footnotetext{
${ }^{154} \mathrm{~A}$ evolução histórica do direito processual brasileiro teria sido uma continuidade da legislação Portuguesa, inspirada no direito romano e canônico, recepcionada no Decreto de 20 out. 1823, herdando-se as normas a partir das ordenações filipinas. In: CINTRA, Antônio Carlos de A., GRINOVER, Ada P., DINAMARCO, Cândido R.. Teoria geral do processo. 22. ed. São Paulo: Malheiros, 2006. p. 111.

${ }^{155}$ SENADO FEDERAL. Decreto n. ${ }^{\circ} 737$, de 25 de novembro de 1850. [...] Disponível em: www.senado.gov.br/legislação/listatextointegral.action?id=64752. Acesso em: 14 abr. 09.

${ }^{156}$ O Código de Processo Civil de 1939 também adotou o princípio de que o que não está nos autos não está no mundo: [...] Art. 118. Na apreciação da prova, o juiz formará livremente o seu convencimento, atendendo aos fatos e circunstâncias constantes dos autos, ainda que não alegados pela parte. [...] Parágrafo único. O juiz indicará na sentença ou despacho os fatos e circunstâncias que motivaram o seu convencimento. In: SENADO FEDERAL. Decreto-lei no 1.608, de 18 de setembro de 1939. [...] Disponível em: www.senado.gov.br/legislação/listatextointegral.action?id=64752. Acesso em: 14 abr. 09.
} 


\section{A Valoração da prova e a verdade formal}

O estudo a respeito da aplicação ao procedimento de cabimento dos recursos especiais do princípio dispositivo ou da verdade formal, em face do reexame ou valoração das provas, importa na consideração de duas ordens de fenômenos, a saber: o primeiro, o surgimento de um tribunal recursal de natureza extraordinária, voltado ao controle da interpretação das leis federais, no caso o Superior Tribunal de Justiça - STJ; e a aplicação das mesmas regras de formação do convencimento judicial aplicáveis à instância recursal ordinária a essa jurisdição.

Quanto ao primeiro fenômeno, o surgimento do STJ como instância recursal extraordinária, a proposta da sua criação originou-se no contexto da crise processual vivida pelo Supremo Tribunal Federal - STF. Em 1987, às vésperas da instalação da Assembléia Nacional Constituinte, havia uma excessiva carga de recursos extraordinários no STF, cujas competências abrangiam tanto as questões de natureza constitucional como as de natureza infraconstitucional, não surtindo efeito a "filtragem" dos recursos, conforme visto a seguir.

Ao longo das décadas em que o recurso extraordinário teve como escopo a preservação da inteireza e da uniformidade da interpretação da Constituição e da lei federal, o Supremo Tribunal Federal foi sofrendo um aumento gradativo do número de recursos, que culminou na denominada 'crise do Supremo '. Visando a solucionar o problema da pletora de recursos, foram criados mecanismos de restrição ao acesso à Suprema Corte, como a argüição de relevância e os óbices regimentais e jurisprudenciais. ${ }^{157}$

Como visto no texto transcrito, a razão imediata para que fosse criado o STJ residia na necessidade de haver uma divisão das tarefas incumbidas ao Supremo Tribunal Federal na competência de apreciar o Recurso Extraordinário.

\footnotetext{
${ }^{157}$ Segundo Bernardo Pimentel: [...] tais expedientes não foram capazes de dar cabo à mencionada crise. [...] a comunidade jurídica nacional passou a prestigiar a solução formulada pelo Professor José Afonso da Silva, de criação de um Tribunal Superior de Justiça, com a principal competência de julgar os recursos envolvendo questões de direito federal infraconstitucional comum. In: SOUZA, Bernardo Pimentel de. Introdução aos recursos cíveis e à ação rescisória. 3. ed. ampl. e atual. São Paulo: Saraiva, 2004. p. 590-591.
} 
No entanto, com a criação da nova Corte foram mantidos os procedimentos de limitação ao cabimento da matéria recursal extraordinária, ensejando a criação de uma jurisprudência semelhante, em vista da origem comum dos recursos extraordinários stricto sensu (STF) e dos especiais, latu sensu (STJ). A identidade de comportamento dos dois órgãos recursais extraordinários nasceu, portanto, do desdobramento da competência do STF, resultando em um tratamento equivalente para os dois órgãos na legislação processual.

Inescusável pensar o modelo brasileiro sem que se aborde o papel do STF conjuntamente com o do STJ porque a competência deste, no que concerne à competência extraordinária, é um desdobramento da competência daquele e oriunda da famosa crise do STF. [...] No caso do STF, esta competência - no que concerne ao seu controle concreto - foi desdobrada, dando origem aos recursos hoje batizados de extraordinário e especial. Embora separados, os recursos tiveram sempre regime semelhante também no CPC e alterações posteriores, o que pode ter sido uma opção infeliz, já que causou diversas dificuldades em vista dessa regulação conjunta. ${ }^{158}$

Do que foi exposto acima, observa-se que a filosofia preconizada na instituição do STJ, a despeito de ser uma solução à chamada crise do STF, tinha um alcance maior, sendo possível supor que a expectativa em relação à nova Corte não se limitava à motivação inicial, podendo existir, nesse particular, a ocorrência de um desvirtuamento de sua finalidade precípua, a que aludem alguns autores. ${ }^{159}$

Por outro lado, essa similitude é referida por alguns doutrinadores como sendo a causa de uma maior duração do processo judicial e de um maior ônus financeiro ao Estado, ao ter que arcar com maiores custos na manutenção administrativa pela demora dos processos judiciais.

Podemos citar que, na prática, recorre-se de tudo por duas vias, já que nunca se sabe qual delas irá prosperar.

${ }^{158}$ COSTA, Henrique Araújo. Reexame de prova em recurso especial: a súmula 7 do STJ. Brasília: Thesaurus, 2008. p. 202-204.

${ }^{159}$ BERTOLDI, Thiago Moraes, RAUCH, Rafael. Superior Tribunal de Justiça: tribunal de sobreposição? In: Interpretação Jurídica. Disponível em: http://www.tex.pro.br/ wwwroot/00/00 tribunal de sobreposição.php. Acesso em: 20 abr. 09. 
Disso, advém uma duração maior do processo e um custo operacional muito maior ao Estado - sem contar a possibilidade de negativa de jurisdição em dúvida sobre tratar-se de questão federal ou constitucional, na hipótese de o jurisdicionado haver optado pelo caminho indevido. ${ }^{160}$

Verifica-se no texto acima, como também em inúmeros julgados a identidade na forma de julgamento entre o STF e o STJ, a exemplo do Recurso Extraordinário n. ${ }^{\circ}$ 15.451-PR, Relator Ministro Lafayette de Andrada, julgado no Plenário do STF em 02/06/1950: “[...] Não cabe recurso extraordinário da decisão da justiça local que se limitou á apreciação da prova de factos e á aplicação aos fatos provados das disposições da Lei que os regiam..."161

Logo, há uma continuidade entre os tipos de recursos extraordinários, desde a atribuição dessa competência ao STF, sem uma mudança substancial com a transferência do encargo de controle das leis a cargo do STJ. A evolução do recurso extraordinário resultou na aprovação do enunciado da Súmula do STF de n. ${ }^{\circ}$ 279, aprovado 13/12/1963, o qual objetivava impedir o reexame de provas, de modo similar ao que o STJ faria dezessete anos depois: "Para simples reexame de prova não cabe recurso extraordinário... ${ }^{162}$

A jurisprudência com base na Súmula STF foi utilizada pelo STJ até a edição do Enunciado $n^{\circ} 7$, não tendo ocorrido conflitos em relação às competências outorgadas ao STJ, competem ao tribunal: o processamento e julgamento de autoridades, nos crimes comuns; da apreciação dos mandados de segurança, habeas data e habeas corpus, contra seus próprios atos e os de autoridades; os conflitos de competência entre tribunais ou entre tribunais e juízes.

Também é da competência do STJ a apreciação dos conflitos de atribuições entre autoridades, envolvendo a União; os recursos ordinários, em mandado de

\footnotetext{
${ }^{160}$ COSTA, Henrique Araújo. Reexame de prova em recurso especial: a súmula 7 do STJ. Brasília: Thesaurus, 2008. p. 202-204.

${ }^{161}$ SUPREMO TRIBUNAL FEDERAL. Disponível em: http://www.stf.jus.br/portal/ jurisprudencia. Acesso em: 24 mar. 2009.

${ }^{162}$ SUPREMO TRIBUNAL FEDERAL. Disponível em: http://www.stf.jus.br/portal/cms/ verTexto.asp? servico=jurisprudenciaSumula. Acesso em:15 out. 2008.
} 
segurança e habeas corpus em última ou única instância por tribunais de segunda instância; em relação às suas decisões, revisões criminais, ações rescisórias, reclamações; e recurso especial. ${ }^{163}$

Em relação às competências gerais, a maior parte foi decorrente da assunção do papel que até então era desempenhado pelo STF, sendo que a maior parte das atribuições do extinto Tribunal Federal de Recursos, cujos componentes compuseram o quadro da primeira investidura do STJ, passaram aos recém criados Tribunais Regionais Federais. ${ }^{164}$

Quanto ao Especial, espécie do gênero Recurso Extraordinário, são da competência do STJ julgar em única ou última instância: decisões recorridas que contrariem ou neguem vigência à lei federal ou tratado; que julguem válida lei ou ato de governo local contra o texto federal; e a divergência entre tribunais, na interpretação da lei. ${ }^{165}$

\subsection{As alternativas a um controle do livre convencimento judicial}

A atuação do Superior Tribunal de Justiça- STJ, em cumprimento a sua função constitucional de controle da uniformidade da legislação federal tem, em relação aos recursos especiais, características próprias, conforme referido no Capítulo 1, quando foi possível observar que o STJ recorre a sua Súmula de jurisprudência como forma de "filtrar" os recursos que deva apreciar e aqueles que sua política de prestação jurisdicional entende que não devam ser submetidos a exame.

A abordagem da questão do controle do livre convencimento judicial, como condição de estabelecimento da verdade processual, passaria no STJ por diversos

\footnotetext{
${ }^{163}$ SENADO FEDERAL. Disponível em: http://www.senado.gov.br/sf/legislacao/const/. Acesso em: 15 out. 2008.

${ }^{164}$ SOUZA, Bernardo Pimentel. Introdução aos recursos cíveis e à ação rescisória. 3. ed. ampl. e atual. São Paulo: Saraiva, 2004. p. 591.

${ }^{165}$ SENADO FEDERAL. Disponível em: http://www.senado.gov.br/sf/legislacao/const/. Acesso em: 15 out. 2008.
} 
expedientes e etapas de seleção e análise dos julgados, até a definição dos recursos que são oferecidos à apreciação e julgamento dos seus colegiados (turmas, seções e Corte Especial).

A primeira forma de controle dos recursos é em relação à própria natureza do RESP, o qual somente tem admitida sua interposição, como visto no Capítulo 1, mediante o prequestionamento de matéria legal, perante aquela que for a última instância recursal ordinária suscetível de reclamação.

Como foi visto na problematização do objeto de pesquisa, quanto ao cabimento dos recursos especiais, se não constar do acórdão aprovado - objeto do recurso - a cogitação da tese prequestionada, o STJ interpreta esse fato como sendo indicativo da ausência do cumprimento daquela condição processual.

Outro mecanismo é a própria jurisprudência do tribunal, ao ser o ponto de referência de legalidade, na fundamentação dos julgamentos (precedentes) e o lugar, onde o tribunal, sem ferir a legislação, estabelece as exceções às suas próprias regras, mediante a declaração que determinado enunciado da súmula não é aplicável a um caso concreto.

O esquema a seguir apresenta uma visão geral do que seria esse processo de "filtragem" dos recursos especiais, identificando os passos principais no exame de cabimento pelo STJ, sem perder de vista, que se trata de uma simplificação, com base nas informações obtidas mediante uma pesquisa amostral, não abrangendo todos os procedimentos e ritos peculiares ao desempenho das atribuições daquele tribunal. 
ESQUEMA 1 - PROCEDIMENTOS DE FILTRAGEM DOS RECURSOS ESPECIAIS

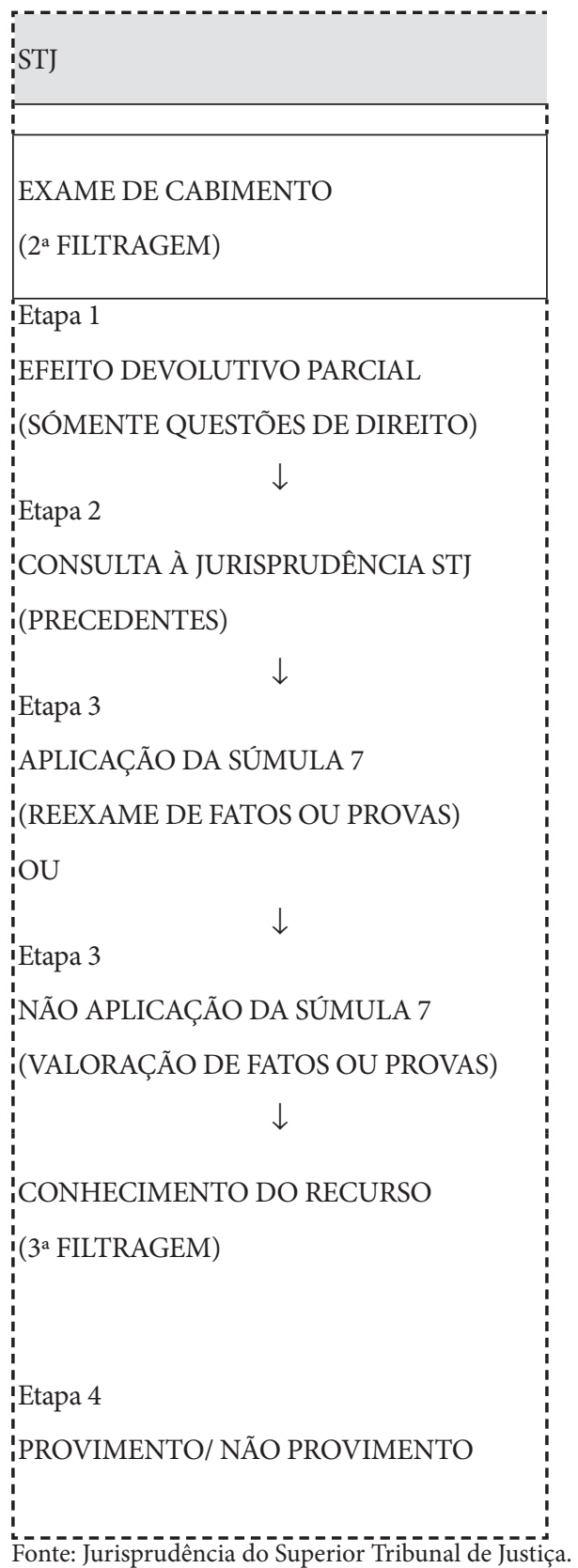

INSTÂNCIA RECURSAL ORDINÁRIA

PREQUESTIONAMENTO

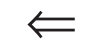

(1 ${ }^{\text {a }}$ FILTRAGEM)
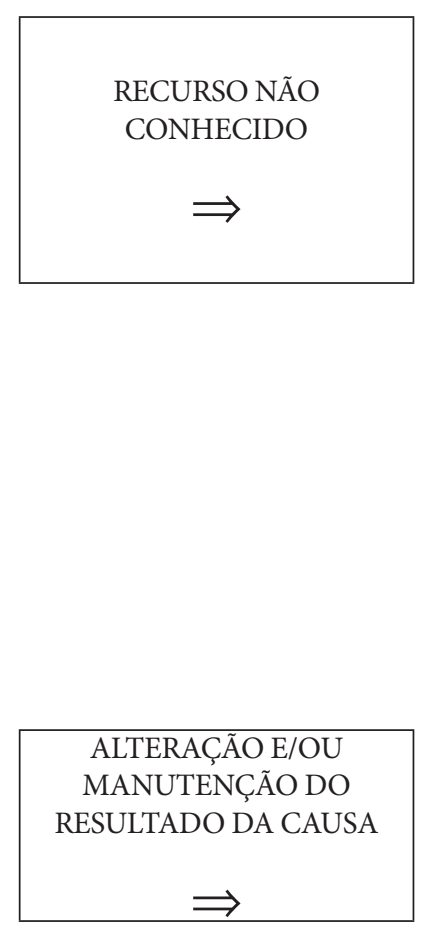
Como se pode observar do esquema acima, haveria pelo menos três processos de filtragem do RESP, desde o momento do seu prequestionamento na instância recursal ordinária, passando pelo exame da incidência da súmula do tribunal ao recurso, até o momento do seu conhecimento no STJ, não importando se o recurso seja provido ou não.

\subsubsection{A utilização de "standards" pelo Superior Tribunal de Justiça}

Antes de proceder à análise acerca da utilização de Standards como controle do livre convencimento motivado do julgador, nos recursos especiais, deve ser observado que a doutrina não apresenta uma teoria a respeito e, como será visto, há dúvidas sobre a viabilidade de criação desses mecanismos no controle da prestação jurisdicional.

[...] Chega-se, então, a um dilema: ou a instrumentação para esse controle existe - e se se deve tentar enunciá-la - ou esse controle deve ser havido como impossível (ou ainda impossível), caso em que seria hora de, quando menos, reconhecê-lo abertamente. Nesse sentido, VITTORIO DENTI põe em evidência duas abordagens teóricas frente à questão: (a) ou se exclui a possibilidade mesma de um controle puramente lógico do juízo de fato, resolvendo esse controle na mera renovação do próprio juízo ou (b) se recorre a parâmetros lógicos, originários do valor de probabilidade em que se fundam as inferências probatórias para efetuá-lo. Trilhada a segunda via, obviamente tem de construir-se um modelo científico capaz de proceder à verificação de tais parâmetros. ${ }^{166}$

Como se observa da transcrição acima, o dilema sobre o controle do livre convencimento do julgador teria duas alternativas: a manutenção da praxe de trabalho calcada em precedentes da jurisprudência; ou a criação de um campo de pesquisa para esse fim.

[...] É justamente para essa problemática que o presente trabalho atenta: existirá um módulo (ou módulos) suscetível

\footnotetext{
${ }^{166}$ KNIJNIK, Danilo. Os "standards" do convencimento judicial: paradigmas para o seu possível controle. In: Academia Brasileira de Direito Processual Civil. Disponível em: http://www.abdpc.org.br/artigos/artigo37.htm. Acesso em: 13 abr. 09.
} 
de utilização pelos operadores jurídicos, para a crítica e o controle do mérito de um convencimento judicial, ou esse controle somente será possível mediante a simples renovação ou repetição do próprio processo de convencimento por um juiz diverso ? Ao que parece, a praxis, pelo menos na realidade brasileira, orienta-se pela pura e simples renovação ou repetição do próprio juízo de fato, como forma de efetuar este controle: os tribunais brasileiros, quando do exame da quaestio facti, em geral reavaliam a prova como um todo, de modo que o mecanismo de controle da convicção judicial acaba reduzindo-se à sua própria renovação. ${ }^{167}$

Conforme visto no texto acima, não apenas o STJ toma por base a sua jurisprudência como critério de garantia de uniformidade do livre convencimento motivado dos julgadores, de onde se concluiria existir uma praxe processual já estabelecida.

\subsubsection{As três formas do livre convencimento motivado do julgador}

Se levado em conta o art. 131 do Código de Processo Civil-CPC, o qual trata da aplicação do princípio do livre convencimento motivado do julgador ao processo de conhecimento, as decisões do STJ fundadas em precedentes da sua jurisprudência ensejariam, em tese, uma contradição com a liberdade de ação proposta pelo princípio acima referido, levando em conta o fato que a amplitude de julgamento estaria limitada às matérias que não estivessem submetidas àquela forma de padronização interpretativa. ${ }^{168}$

$\mathrm{O}$ artigo acima referido estabelece em relação ao juiz singular, in verbis: “O juiz apreciará livremente a prova, atendendo aos fatos e circunstâncias constantes dos autos, ainda que não alegados pelas partes; mas deverá indicar, na sentença, os motivos que lhe formaram o convencimento.." 169

\footnotetext{
${ }^{167}$ Ibidem.

${ }^{168}$ DINIZ, Maria Helena. As lacunas no direito. 8. ed. adap. São Paulo: Saraiva, 2007. p. 269270.

${ }^{169}$ BRASIL. Constituição federal, código civil, código de processo civil. Organizador Yussef Said Cahali. 3. ed. rev.atual. e ampl. São Paulo: Editora Revista dos Tribunais, 2001. p. 447.
} 
Como o texto legal em questão remete aos procedimentos da competência do juiz de primeira instância, poderia ser questionada a aplicação do princípio do livre convencimento também na instância recursal extraordinária, a qual se reveste de natureza diferenciada em relação ao processo de conhecimento. ${ }^{170}$

Supondo viável a aplicação do princípio a todos os julgadores, o art. 131 do CPC abordaria: o direito de investigar as provas livremente; o dever de justificar sua decisão; e a obrigação de ater-se aos fatos e circunstâncias dos autos em que ocorre a lide. ${ }^{171}$

ESQUEMA 2 - Formas do Livre Convencimento do Julgador

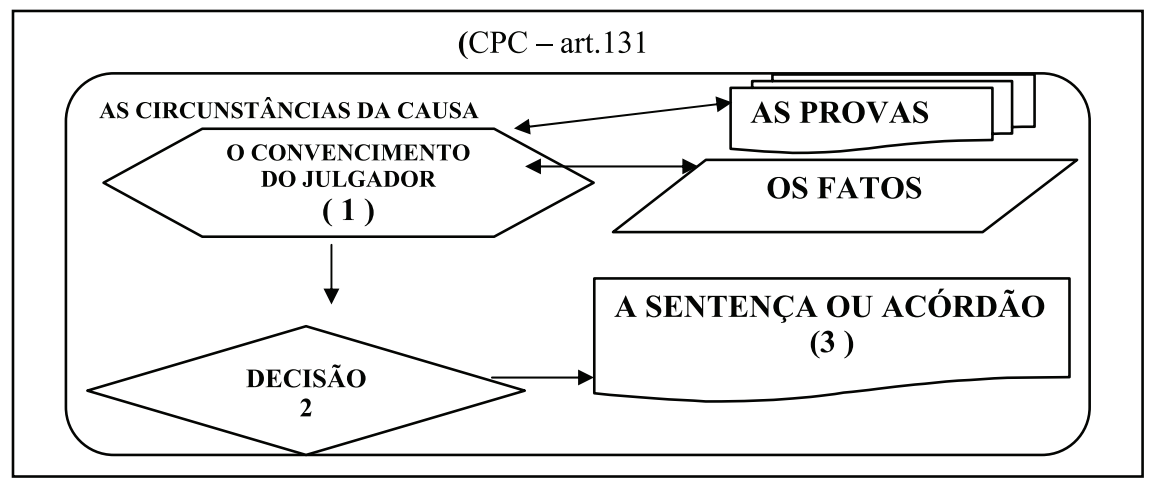

Fonte: Editor de Textos Word. Menu “inserir”, opções: “Ilustrações”, “formas”, “fluxograma” ou "linhas".

Do esquema acima se verifica que o julgador, na instância recursal ordinária, teria à sua disposição inúmeras combinações, entre fatos, provas e circunstâncias, para fundamentar a decisão judicial, existindo, do ponto de vista hipotético, um controle satisfatório do livre convencimento, pela legislação processual. Entretanto, em relação à instância recursal extraordinária, como visto no Capítulo 1,0 controle do livre convencimento aconteceria apenas em relação à jurisprudência

\footnotetext{
${ }^{170}$ SUPERIOR TRIBUNAL DE JUSTIÇA. 3a Turma. Ag Rg no Ag n.o 1.047.677/SP. [...] Relator Ministro Massami Uyeda. Brasilia, DF, 03 mar. 09. DJe de 13 mar. 09.

${ }^{171}$ GRAU, Eros Roberto. Ensaio e discurso sobre a interpretação/aplicação do direito. 3 . ed. São Paulo: Malheiros, 2005. p. 40.
} 
do STJ (controle interno) e não em relação à efetividade social da prestação jurisdicional (controle externo).

Quanto à efetividade das decisões judiciais, a análise pretendida demanda um referencial teórico adequado ao contexto da prestação jurisdicional, implicando, no caso, em uma perspectiva de classificação do sistema normativo, com foco no interesse social. ${ }^{172}$

Logo, na perspectiva da função social do direito, a perspectiva de estabelecimento do controle do convencimento judicial do julgador aconteceria, tendo por referência um sistema normativo do tipo circular. ${ }^{173}$

Nesse sistema normativo, não haveria predominância de uma hierarquização das prescrições jurídicas ou ponderação de valores mediante princípios, na solução de casos concretos, pois a ênfase se daria pela interação com outros sistemas sociais, de modo a ajustar o direito às demandas sociais e econômicas. ${ }^{174}$

\subsubsection{Os postulados normativos aplicativos como forma de controle}

A partir dos elementos apresentados na pesquisa, é possível supor que já existiriam formas eficazes de controle do convencimento motivado do julgador, muito embora não tenham, por definição, o intuito de garantir a liberdade plena do julgador. Para os fins do presente capítulo serão utilizados os critérios da doutrina para o exame de postulados normativos aplicativos, conforme explicitado nas técnicas de pesquisa apresentadas no Capítulo 2. Como ponto de partida, haveria o fluxo de controle realizado pelo STJ, o qual foi identificado no decorrer da pes-

${ }^{172}$ COSTA, Fábio Silva, Hermenêutica jurídica e direito contemporâneo: estudo acerca da operacionalidade do método interpretativo sistemático perante a redefinição paradigmática da ordem jurídica. São Paulo: Juarez de Oliveira, 2004. p. 73.

${ }^{173}$ Segundo Fábio Costa: "[...] Associa-se a um direito material, cuja fonte é a própria dinâmica da sociedade. In: Ibidem. p. 74.

${ }^{174}$ COSTA, Fábio Silva, Hermenêutica jurídica e direito contemporâneo: estudo acerca da operacionalidade do método interpretativo sistemático perante a redefinição paradigmática da ordem jurídica. São Paulo: Juarez de Oliveira, 2004. p. 74-75. 
quisa, onde são apresentados os principais elementos de análise pelo tribunal, cujo ponto central é o Enunciado n. ${ }^{\circ} 7$ da Súmula de jurisprudência do STJ.

ESQUEMA 3 - O CONTROLE DO LIVRE CONVENCIMENTO MOTIVADO PELA APLICAÇÃO DA JURISPRUDÊNCIA DO STJ

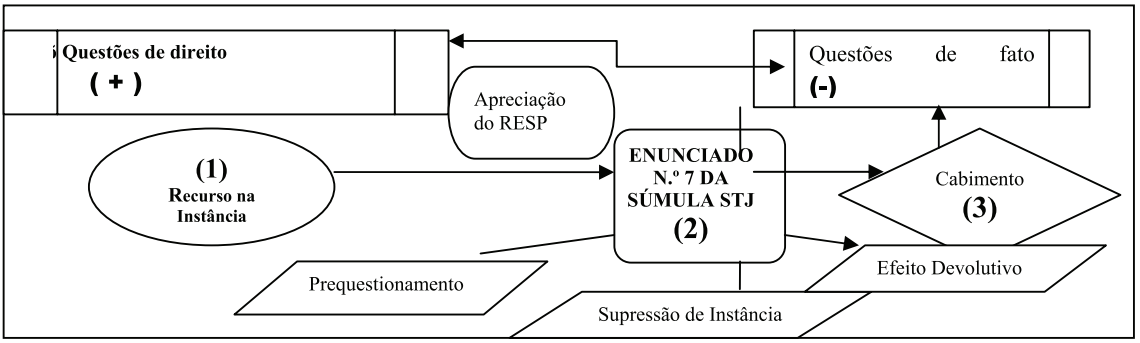

Fonte: Editor de Textos Word. Menu "inserir", opções: "Ilustrações", "formas", "fluxograma" ou "linhas". Base: Jurisprudência do Superior Tribunal de Justiça.175

Em relação ao esquema apresentado estão descritos os principais argumentos apresentados pelo STJ, na sua jurisprudência, cabendo ressaltar a sua natureza parcial, sendo o resultado de um levantamento amostral em uma base de dados de jurisprudência de grande porte, conforme referido no Subitem 2.3 do Capítulo 2.

Quanto aos postulados normativos, foram analisadas, por amostra, decisões às quais não se aplicaria o Enunciado n. ${ }^{\circ}$ 7: 2 (duas) medidas cautelares, 3 (três) ações rescisórias, uma do Tribunal Federal de Recursos - TFR e 3 (três) mandados de segurança. ${ }^{176}$

\author{
MEDIDA CAUTELAR N. ${ }^{\circ} 3.481$ - SP \\ RELATOR: MINISTRO FRANCISCO FALÇÃO \\ $1^{\text {a }}$ TURMA - JULGAMENTO EM: 19/02/2002
}

\footnotetext{
${ }^{175}$ SUPERIOR TRIBUNAL DE JUSTIÇA. Disponível em: http://www.stj.jus.br/scon/ pesquisar.jsp. Acesso em: 15 out. 2008.

${ }^{176}$ SUPERIOR TRIBUNAL DE JUSTIÇA. Disponível em: http://www.stj.jus.br/scon/ pesquisar.jsp. Acesso em: 15 out. 2008.
} 
EMENTA (excertos): [...] - Recurso especial intentado com o fundamento de que a transação realizada abrangeu o valor do tributo e da obrigação acessória, enquanto que o acórdão recorrido entendeu que a transação contemplou somente o valor do tributo. Incidência das Súmulas 05 e 07, desta Corte. - Com a inviabilidade do recurso especial, resta ausente o pressuposto do "fumus boni iuris". - Medida cautelar improcedente.

ANÁLISE: O julgamento seria o seguinte: "Se o recurso especial pode ser admitido, logo a medida cautelar pode ser admitida, pois o RESP é a evidência legal da cautelar.' Ocorre que as medidas cautelares, por sua natureza, não tem necessidade de um juízo exaustivo da legalidade, como decidido. Ora, se o RESP tivesse sido admitido, não haveria cautelar, pois não existiria a motivação a ser satisfeita.

\section{AGRAVO REGIMENTAL NA MEDIDA CAUTELAR N. ${ }^{\circ} 14.173$ - SP \\ RELATOR: MINISTRO ALDIR PASSARINHO JÚNIOR \\ 4a TURMA - JULGAMENTO EM: 17/06/2008}

EMENTA (excertos): [...] I - Rejeita-se a medida cautelar quando não se identificam, de pronto, em conjunto, seus requisitos essenciais no tocante à tese defendida na inicial, que visa emprestar efeito suspensivo a recurso especial que manteve a penhora e o praceamento de bem imóvel, cuja índole de bem de família, afirmado o contrário pelo Tribunal Estadual, depende da interpretação de matéria fática. II - "A pretensão de simples reexame de prova não enseja recurso especial" (Súmula n. 7-STJ).

ANÁLISE: O STJ buscou, mais uma vez, a sua jurisprudência como critério de análise da fundamentação da cautelar. Acontece que a aplicação da meta norma (súmula) seria ao objeto enunciado em seu texto e não em relação à sua livre aplicação a qualquer medida jurisdicional. Em um discurso prático, o que o STJ está dizendo é que: "Como a argumentação não apresenta satisfatoriamente os fundamentos exigidos para a concessão do pedido, mesmo que falta uma lei para fundamentar a decisão de negativa à cautelar, então se aplica, por analogia, o enunciado dos RESP.". 


\section{AÇÃO RESCISÓRIA N. ${ }^{\circ} 1.004$ - CE /TFR \\ RELATOR: MINISTRO DIAS TRINDADE \\ 1ª SEÇÃO - JULGAMENTO EM: 08/04/1987}

EMENTA (excertos): [...] É inadmissível ação rescisória, com suporte em violação de literal disposição de lei, quando tal depende de reexame de valoração da prova produzida no processo em que proferida a decisão rescindenda. $\mathrm{O}$ que autoriza a desconstituição de sentença de mérito com trânsito em julgado e ofensa a norma, não a parte, por eventual defeito de apreciação da prova ou de interpretação dos fatos.

ANÁLISE: Nessa decisão o TFR simplesmente disse que não podia haver reexame, sem explicar por qual motivo, a regra de cabimento dos recursos especiais seria aplicada nesse caso. Ao que parece a idéia de recusa a exame de questões de fato, seria que o tribunal, em qualquer julgado, somente trata com questões explícitas de direito. Mas se assim fosse, como o TFR poderia estabelecer as exceções da valoração da prova?

\section{AÇÃO RESCISÓRIA N. ${ }^{\circ} 1.470$ - SP \\ RELATOR: MINISTRO CASTRO FILHO \\ 2a SEÇÃO - JULGAMENTO EM: 10/05/2006}

EMENTA (excertos): [...] II - Consoante a firme orientação jurisprudencial desta Corte, "A rescisória não se presta a apreciar a boa ou má interpretação dos fatos, ao reexame da prova produzida ou a sua complementação. Em outras palavras, a má apreciação da prova ou a injustiça da sentença não autorizam a ação rescisória (REsp 147.796/MA, DJ 28/06/99, Rel. Min. Sálvio de Figueiredo Teixeira).

ANÁLISE: Novamente o STJ, sem outra previsão normativa, adota como lei entre as partes, o simples enunciado de um julgado de matéria de outra espécie, visando exercer o controle (negativo) de cabimento de ações rescisória, quando poderia fazê-lo invocando a norma jurídica que trata do instituto (lei). Assim agindo, o STJ universaliza, como um verdadeiro paradigma, o enunciado $n .{ }^{\circ} 7$ da sua Súmula, como resposta a qualquer provimento judicial. 


\author{
AÇÃO RESCISÓRIA N. ${ }^{\circ} 3.573$ - PB \\ RELATOR: MINISTRO HUMBERTO GOMES DE BARROS \\ 2a SEÇÃO - JULGAMENTO EM: 10/10/2007
}

EMENTA (excertos): [...] 1. Antes da EC 45/2004 a Justiça comum estadual detinha competência para apreciar ação de indenização por acidente de trabalho. Por uso, é improcedente o pedido de rescisão - fundado em alegada incompetência - da sentença por ela proferida antes da referida alteração constitucional. 2. A ação rescisória baseada no art. 485, V, do CPC, exige que o autor demonstre clara, objetiva e fundamentadamente de que forma a decisão rescindenda ofendeu literalidade de Lei. Do contrário, valioso instrumento destinado ao ataque à coisa julgada indevidamente formulada transforma-se em recurso ordinário, voltado ao reexame de decisões judiciais.

ANÁLISE: Embora a assertiva do STJ esteja correta, da análise dos requisitos legais para a concessão, novamente insere a regra da interpretação subjetiva para fundamentar sua decisão, o que pode ser sintetizado no seguinte discurso: "Se há falta de um argumento de fundamentação, mesmo que a lei seja suficiente para esclarecer o caso (regra do CPC), ainda assim, o postulado deve ser apresentado (reexame), como uma justificativa de proteção à tradição processual adotada (primazia das questões de direito).”.

\author{
MANDADO DE SEGURANÇA N. ${ }^{\circ} 9.539$ - DF \\ RELATOR: MINISTRO PAULO MEDINA \\ 3a SEÇÃO - JULGAMENTO EM: 12/05/2004
}

EMENTA (excertos): [...] O Poder Judiciário, em sede de mandado de segurança, não pode reapreciar provas nem adentrar no mérito administrativo. Segurança denegada.

ANÁLISE: Novamente o discurso do STJ é no sentido de reafirmar sua posição, pois não haveria necessidade além de simplesmente cotejar a norma sobre o mandado de segurança e afirmar a compatibilidade ou não do pedido às exigências legais. Na verdade, no mandado de segurança, o que deveria ser examinado era a 
verossimilhança do pedido, e a evidência da violação legal de forma imediata, não importando o meio utilizado, contanto que não houvesse a dilação probatória. No caso, o STJ tomou a norma administrativa como sendo de natureza jurisdicional, para não ser reexaminada. "Se um ato administrativo apreciou uma prova, então não há como reexaminá-la, pois seria uma supressão de autoridade administrativa".

AGRAVO REGIMENTAL EM MANDADO DE SEGURANÇA N. ${ }^{\circ}$ 17.919 - PR RELATOR: MINISTRA NANCY ANDRIGHI

3a TURMA - JULGAMENTO EM: 14/09/2004

EMENTA (excertos): [...] A questão da legitimidade da representação, já examinada nos autos, enfrenta o óbice da Súmula 7 deste STJ. A decisão agravada ao privilegiar o princípio da unicidade recursal, afasta a condição de terceiro, reconhecendo que o Sindicato atua exatamente em nome e em favor dos interesses dos ora agravantes, como substituto processual, razão de ser inaplicável a Súmula 202/ STJ. Agravo não provido.

ANÁLISE: O STJ contradiz seu pensamento que em sede de mandado de segurança não reexamina fatos e provas, pois ao ponderar as decisões anteriores do tribunal, reexaminou o fato de que a legitimidade do sindicato era questionada. Além disso, utilizou o critério de reexame (RESP) na apreciação de medida de urgência (perigo da demora e fumaça do bom direito), não apontando, em nenhum momento, qual quesito da norma de concessão da segurança não fora atendida.

\section{RECURSO EM MANDADO DE SEGURANÇA N. ${ }^{\circ} 21.409$ - GO RELATOR: MINISTRO HERMAN BENJAMIN \\ 2a TURMA - JULGAMENTO EM: 12/06/2007}

EMENTA (excertos): [...] 1. Em sede de controle do exercício do poder disciplinar da Administração, incumbe ao Superior Tribunal de Justiça zelar pelo cumprimento das garantias constitucionais e legais da ampla defesa, do contraditório e do devido processo legal, sendo-lhe vedado, por força da Súmula 7, reapreciar provas colhidas, exceto na hipótese de flagrante e grave desrespeito à realidade dos fatos. [...] "É vedado ao Superior Tribunal de Justiça a discussão, em sede de 
recurso ordinário, de matéria não debatida na origem, por caracterizar supressão de instância. Precedentes." (RMS 16.927/ES, Rel. Min. Arnaldo Esteves Lima, DJ 24/4/2006).

ANÁLISE: Aqui o STJ reconhece a possibilidade de exceção ao reexame de provas, nos casos extremos, mas o que se evidencia, mais uma vez é que a regra de cabimento dos recursos especiais, embora contradiga seu próprio enunciado, é regra geral para todos os exames de cabimento da competência do tribunal.

\subsection{A valoração da prova na hermenêutica filosófica}

Os critérios utilizados para a análise a seguir são relacionados com os conceitos de pré-noção, contexto histórico, as noções de todo e de parte, a fusão de horizontes, o diálogo como ponto de intercâmbio de percepções e o círculo hermenêutico, na perspectiva preconizada pela Hermenêutica Filosófica, apresentada por Hans-Georg Gadamer, embora se trate de um ensaio de leitura jurisprudencial, onde muitas vezes não se mostra factível a utilização prática dos referidos conceitos.

\section{MEDIDA CAUTELAR N. ${ }^{\circ} 3.481$ - SP \\ RELATOR: MINISTRO FRANCISCO FALÇÃO \\ 1a TURMA - JULGAMENTO EM: 19/02/2002}

EMENTA (excertos): [...] - Recurso especial intentado com o fundamento de que a transação realizada abrangeu o valor do tributo e da obrigação acessória, enquanto que o acórdão recorrido entendeu que a transação contemplou somente o valor do tributo. Incidência das Súmulas 05 e 07, desta Corte. - Com a inviabilidade do recurso especial, resta ausente o pressuposto do "fumus boni iuris". - Medida cautelar improcedente.

ANÁLISE: Se o motivo do pedido é a relação entre a parte (obrigação acessória) e o todo (tributação), caberia estabelecer o critério lógico de interpretação, no exame do fato e não do argumento externo (inviabilidade do recurso). Ao julgar assim, generalizou a concepção que parcelas acessórias dissociadas do tributo, o 
que poderia conflitar com a própria regra tributária. Reafirmou o STJ sua pré-noção e a do julgador ordinário, quando poderia ter privilegiado uma fusão de horizontes, estabelecendo uma interpretação recursal mais adequada ao que foi pedido pela parte.

\section{AGRAVO REGIMENTAL NA MEDIDA CAUTELAR N. ${ }^{\circ} 14.173$ - SP \\ RELATOR: MINISTRO ALDIR PASSARINHO JÚNIOR \\ 4a TURMA - JULGAMENTO EM: 17/06/2008}

EMENTA (excertos): [...] I - Rejeita-se a medida cautelar quando não se identificam, de pronto, em conjunto, seus requisitos essenciais no tocante à tese defendida na inicial, que visa emprestar efeito suspensivo a recurso especial que manteve a penhora e o praceamento de bem imóvel, cuja índole de bem de família, afirmado o contrário pelo Tribunal Estadual, depende da interpretação de matéria fática. II - "A pretensão de simples reexame de prova não enseja recurso especial" (Súmula n. 7-STJ). III - Agravo improvido.

ANÁLISE: Não houve a tentativa de fusão dos horizontes da interpretação do tribunal recorrido e da parte, o que em situação concreta passível de comprovação, mostra-se ilógico. O STJ, caso tivesse procedido ao reexame do contexto histórico fático, buscando considerar o todo (a causa) e a parte (cautelar), teria contribuído com uma regra processual lógica e clara, estabelecendo um diálogo entre as instâncias jurisdicionais.

\section{AÇÃO RESCISÓRIA N. ${ }^{\circ} 1.004$ - CE / TFR \\ RELATOR: MINISTRO DIAS TRINDADE \\ 1a SEÇÃO - JULGAMENTO EM: 08/04/1987}

EMENTA (excertos): [...] É inadmissível ação rescisória, com suporte em violação de literal disposição de lei, quando tal depende de reexame de valoração da prova produzida no processo em que proferida a decisão rescindenda. $\mathrm{O}$ que autoriza a desconstituição de sentença de mérito com trânsito em julgado e ofensa a norma, não a parte, por eventual defeito de apreciação da prova ou de interpretação dos fatos. 
ANÁLISE: O TFR não conseguiu fugir à pré-noção de subsunção imediata do fato alegado à norma legal aplicável. Agindo dessa maneira, reafirmou exclusivamente seu ponto de vista já instituído na sua súmula, sem procurar estabelecer um horizonte de análise nos próprios fatos alegados, deixando de aprimorar os seus mecanismos de julgamento, além de não ter uma visão de totalidade que permitisse uma relação dialógica entre o preceito jurisprudencial e os fatos novos à disposição de sua análise.

\author{
AÇÃO RESCISÓRIA N. ${ }^{\circ} 1.470$ - SP \\ RELATOR: MINISTRO CASTRO FILHO \\ 2a SEÇÃO - JULGAMENTO EM: 10/05/2006
}

EMENTA (excertos): [...] II - Consoante a firme orientação jurisprudencial desta Corte, "A rescisória não se presta a apreciar a boa ou má interpretação dos fatos, ao reexame da prova produzida ou a sua complementação. Em outras palavras, a má apreciação da prova ou a injustiça da sentença não autorizam a ação rescisória (REsp 147.796/MA, DJ 28/06/99, Rel. Min. Sálvio de Figueiredo Teixeira).

ANÁLISE: No caso concreto o STJ não procurou perceber, em um processo de fusão do seu horizonte ao do recorrente, quais argumentos existiriam em reforço ao pedido apresentado. Além disso, recorreu à sua pré-noção de que a forma de alienação do bem é motivo suficiente da caracterização da má-fé do devedor, sem considerar as causas que justificaram o comportamento. No caso de má-fé, o exame dos fatos teria reafirmado a prática executória, ampliando ao todo a lição da parte.

\author{
AÇÃO RESCISÓRIA N. ${ }^{\circ} 3.573$ - PB \\ RELATOR: MINISTRO HUMBERTO GOMES DE BARROS \\ 2a SEÇÃO - JULGAMENTO EM: 10/10/2007
}

EMENTA (excertos): [...] 2. A ação rescisória baseada no art. 485, V, do $\mathrm{CPC}$, exige que o autor demonstre clara, objetiva e fundamentadamente de que forma a decisão rescindenda ofendeu literalidade de Lei. Do contrário, valioso instrumento destinado ao ataque à coisa julgada indevidamente formulada transforma-se em recurso ordinário, voltado ao reexame de decisões judiciais. 
ANÁLISE: O tribunal não estabeleceu o horizonte de sua análise, pois não indicou o ponto onde a alegação não atendeu à regra legal e buscou reafirmar uma pré-noção (reexame) fora do contexto de aplicação (RESP).

\author{
MANDADO DE SEGURANÇA N. ${ }^{\circ} 9.539$ - DF \\ RELATOR: MINISTRO PAULO MEDINA \\ 3a SEÇÃO - JULGAMENTO EM: 12/05/2004
}

EMENTA (excertos): [...] Verificado o respeito aos princípios do contraditório e da ampla defesa, com citação válida, oportunidade de defesa e exposição dos fatos de que o servidor deve se defender, não há que se falar em nulidade do processo administrativo, porque o acusado não foi ouvido pela comissão de sindicância, na fase probatória do processo administrativo disciplinar. O Poder Judiciário, em sede de mandado de segurança, não pode reapreciar provas nem adentrar no mérito administrativo. Segurança denegada.

ANÁLISE: Houve uma fusão de horizontes, mas entre o STJ e o recorrido, quando a análise era do pleito do recorrente. Assim, o tribunal usou uma pré-noção, de forma não isonômica, não concretizando um círculo hermenêutico de compreensão do pedido objeto do recurso.

AGRAVO REGIMENTAL EM MANDADO DE SEGURANÇA N.o 17.919 - PR RELATOR: MINISTRA NANCY ANDRIGHI

3a TURMA - JULGAMENTO EM: 14/09/2004

EMENTA (excertos): [...] A questão da legitimidade da representação, já examinada nos autos, enfrenta o óbice da Súmula 7 deste STJ. A decisão agravada ao privilegiar o princípio da unicidade recursal, afasta a condição de terceiro, reconhecendo que o Sindicato atua exatamente em nome e em favor dos interesses dos ora agravantes, como substituto processual, razão de ser inaplicável a Súmula 202/ STJ. Agravo não provido.

ANÁLISE: A pré-noção da regra dos recursos especiais foi utilizada, como justificativa para não se realizar uma fusão de horizontes entre o pedido no recur- 
so e o exame lógico das normas no caso concreto, impedindo a realização de um diálogo entre Estado (jurisdição) e a parte.

\author{
RECURSO EM MANDADO DE SEGURANÇA N. ${ }^{\circ} 21.409$ - GO \\ RELATOR: MINISTRO HERMAN BENJAMIN \\ 2a TURMA - JULGAMENTO EM: 12/06/2007
}

EMENTA (excertos): [...] 1. Em sede de controle do exercício do poder disciplinar da Administração, incumbe ao Superior Tribunal de Justiça zelar pelo cumprimento das garantias constitucionais e legais da ampla defesa, do contraditório e do devido processo legal, sendo-lhe vedado, por força da Súmula 7, reapreciar provas colhidas, exceto na hipótese de flagrante e grave desrespeito à realidade dos fatos. [...] "É vedado ao Superior Tribunal de Justiça a discussão, em sede de recurso ordinário, de matéria não debatida na origem, por caracterizar supressão de instância. Precedentes." (RMS 16.927/ES, Rel. Min. Arnaldo Esteves Lima, DJ 24/4/2006).

ANÁLISE: O STJ aplicou a pré-noção jurisdicional na esfera administrativa. Como também não estabeleceu uma fusão de horizontes com a parte recorrente, pois não estabeleceu um diálogo ao impor a pré-noção do RESP ao fato administrativo.

\title{
3.3 A valoração da prova na teoria da ação comunicativa
}

Não havendo condições, para o debate acerca de conceitos fundamentais da obra de Jürgen Habermas: Sistema, Mundo da Vida, agir comunicativo, agir estratégico, consciência moral, entre outros, a análise dos julgados apresentada leva em consideração o conceito de situação ideal de fala, da Teoria da Ação Comunicativa.

\author{
MEDIDA CAUTELAR N. ${ }^{\circ} 3.481$ - SP \\ RELATOR: MINISTRO FRANCISCO FALÇÃO \\ 1a TURMA - JULGAMENTO EM: 19/02/2002
}


EMENTA (excertos): [...] - Recurso especial intentado com o fundamento de que a transação realizada abrangeu o valor do tributo e da obrigação acessória, enquanto que o acórdão recorrido entendeu que a transação contemplou somente o valor do tributo. Incidência das Súmulas 05 e 07, desta Corte. - Com a inviabilidade do recurso especial, resta ausente o pressuposto do "fumus boni iuris". - Medida cautelar improcedente.

ANÁLISE: O STJ não estabeleceu o consenso sobre seu discurso, pois não abordou a questão argüida pelo recorrente: o reconhecimento do pagamento abrangendo todas as obrigações. Não apresentou motivos para a aplicação de regras de cabimento de RESP a medida cautelar.

\title{
AGRAVO REGIMENTAL NA MEDIDA CAUTELAR N. ${ }^{\circ} 14.173$ - SP \\ RELATOR: MINISTRO ALDIR PASSARINHO JÚNIOR \\ 4a TURMA - JULGAMENTO EM: 17/06/2008
}

EMENTA (excertos): [...] I - Rejeita-se a medida cautelar quando não se identificam, de pronto, em conjunto, seus requisitos essenciais no tocante à tese defendida na inicial, que visa emprestar efeito suspensivo a recurso especial que manteve a penhora e o praceamento de bem imóvel, cuja índole de bem de família, afirmado o contrário pelo Tribunal Estadual, depende da interpretação de matéria fática. II - "A pretensão de simples reexame de prova não enseja recurso especial” (Súmula n. 7-STJ).

ANÁLISE: O STJ não estabeleceu uma situação ideal de fala, já que não concordou com a afirmação da parte, além de negar argumentos para a analogia entre regras de recursos especiais e espécie em análise.

\author{
AÇÃO RESCISÓRIA N. ${ }^{\circ} 1.004$ - CE / TFR \\ RELATOR: MINISTRO DIAS TRINDADE \\ 1 SEÇÃO - JULGAMENTO EM: 08/04/1987
}

EMENTA (excertos): [...] É inadmissível ação rescisória, com suporte em violação de literal disposição de lei, quando tal depende de reexame de valoração da 
prova produzida no processo em que proferida a decisão rescindenda. O que autoriza a desconstituição de sentença de mérito com trânsito em julgado e ofensa a norma, não a parte, por eventual defeito de apreciação da prova ou de interpretação dos fatos.

ANÁLISE: O TFR levou em conta o argumento de revisão do requerente, em seu desfavor, ao cassar o julgamento. Tal prática reitera o senso comum jurídico, de que o tribunal decide sozinho as causas que lhe são submetidas, sem necessidade de realização de um consenso pela fala (verdade pragmática).

\author{
AÇÃO RESCISÓRIA N. ${ }^{\circ} 1.470$ - SP \\ RELATOR: MINISTRO CASTRO FILHO \\ 2a SEÇÃO - JULGAMENTO EM: 10/05/2006
}

EMENTA (excertos): [...] II - Consoante a firme orientação jurisprudencial desta Corte, "A rescisória não se presta a apreciar a boa ou má interpretação dos fatos, ao reexame da prova produzida ou a sua complementação. Em outras palavras, a má apreciação da prova ou a injustiça da sentença não autorizam a ação rescisória (REsp 147.796/MA, DJ 28/06/99, Rel. Min. Sálvio de Figueiredo Teixeira).

ANÁLISE: A discursividade não aconteceu em relação ao recorrente, pois a argumentação do STJ foi em concordância com o tribunal recorrido, sem uma análise dos argumentos da parte autora do recurso. Tal comportamento desviou o foco do recurso para a cooperação entre o STJ e o outro órgão jurisdicional, sem o mesmo procedimento em relação ao recorrente.

\author{
AÇÃO RESCISÓRIA N. ${ }^{\circ} 3.573$ - PB \\ RELATOR: MINISTRO HUMBERTO GOMES DE BARROS \\ 2a SEÇÃO - JULGAMENTO EM: 10/10/2007
}

EMENTA (excertos): [...] 2. A ação rescisória baseada no art. 485, V, do $\mathrm{CPC}$, exige que o autor demonstre clara, objetiva e fundamentadamente de que forma a decisão rescindenda ofendeu literalidade de Lei. Do contrário, valioso instrumento destinado ao ataque à coisa julgada indevidamente formulada transforma-se em recurso ordinário, voltado ao reexame de decisões judiciais. 
ANÁLISE: O argumento do STJ em relação ao reexame não tinha pertinência com o caso, por não se tratar de cabimento de recurso especial.

\author{
MANDADO DE SEGURANÇA N. ${ }^{\circ} 9.539$ - DF \\ RELATOR: MINISTRO PAULO MEDINA \\ 3a SEÇÃO - JULGAMENTO EM: 12/05/2004
}

EMENTA (excertos): [...] O Poder Judiciário, em sede de mandado de segurança, não pode reapreciar provas nem adentrar no mérito administrativo. Segurança denegada.

ANÁLISE: O estabelecimento de uma situação ideal de fala não foi realizado pelo STJ, o qual não analisou os argumentos do recorrente, limitando-se ao discurso estratégico de provar sua verdade pela invocação de uma regra geral (RESP), a qual teria uma natureza metafísica de tudo explicar. Dessa forma, não realizou o STJ a prática do consenso discursivo.

AGRAVO REGIMENTAL EM MANDADO DE SEGURANÇA N. ${ }^{\circ}$ 17.919 - PR RELATOR: MINISTRA NANCY ANDRIGHI

3a TURMA - JULGAMENTO EM: 14/09/2004

EMENTA (excertos): [...] A questão da legitimidade da representação, já examinada nos autos, enfrenta o óbice da Súmula 7 deste STJ. A decisão agravada ao privilegiar o princípio da unicidade recursal, afasta a condição de terceiro, reconhecendo que o Sindicato atua exatamente em nome e em favor dos interesses dos ora agravantes, como substituto processual, razão de ser inaplicável a Súmula 202/ STJ. Agravo não provido.

ANÁLISE: O posicionamento do STJ cria uma desigualdade discursiva, pois de sua parte, analisa o que considera oportuno no teor do recurso e, de outro lado, impede que a parte ofereça suas alegações, quanto a fatos e provas, usando uma regra particular em casos não particulares. 


\author{
RECURSO EM MANDADO DE SEGURANÇA N. ${ }^{\circ} 21.409$ - GO \\ RELATOR: MINISTRO HERMAN BENJAMIN \\ 2a TURMA \\ JULGAMENTO EM: 12/06/2007
}

EMENTA (excertos): [...] 1. Em sede de controle do exercício do poder disciplinar da Administração, incumbe ao Superior Tribunal de Justiça zelar pelo cumprimento das garantias constitucionais e legais da ampla defesa, do contraditório e do devido processo legal, sendo-lhe vedado, por força da Súmula 7, reapreciar provas colhidas, exceto na hipótese de flagrante e grave desrespeito à realidade dos fatos. [...] "É vedado ao Superior Tribunal de Justiça a discussão, em sede de recurso ordinário, de matéria não debatida na origem, por caracterizar supressão de instância. Precedentes." (RMS 16.927/ES, Rel. Min. Arnaldo Esteves Lima, DJ 24/4/2006).

ANÁLISE: O posicionamento do STJ cria uma desigualdade discursiva, pois de sua parte, analisa o que considera oportuno no teor do recurso e, de outro lado, impede que a parte ofereça suas alegações, quanto a fatos e provas, usando uma regra particular em casos não particulares.

\title{
3.4 As impressões a respeito das soluções teóricas utilizadas
}

A procura por uma teoria que desse suporte a uma análise do discurso do direito, sem utilização apenas de conceitos jurídicos, teve como resultado a combinação de duas perspectivas hermenêuticas não convencionais: a teoria do círculo hermenêutico como meio de busca da verdade, no contexto histórico de existência, no enfoque de Hans-Georg Gadamer e a verdade por meio da ação comunicativa, em Jürgen Habermas.

Correu-se o risco de não aprofundar devidamente as formulações filosóficos de ambos os autores, o que efetivamente acontece, em um trabalho monográfico, especialmente se levada em conta a profundidade e a amplitude da bibliografia de ambos os autores. Por outro lado, a combinação de duas perspectivas quase 
opostas, teve como ponto positivo mostrar a sua complementaridade, revelada nas formas distintas de priorização do diálogo, entre diferentes (fusão de horizontes em Gadamer) e os que se fazem iguais (a situação ideal de fala em Habermas).

Contudo, não foram abertas discussões sobre inúmeros aspectos da teoria referenciada, em face da inviabilidade de definição do objeto de pesquisa, ou mesmo pela falta de um referencial teórico mais elaborado pelo autor. Nesse sentido, não foi questionada a chamada reviravolta linguística da filosofia, a qual não se realiza de forma automática, pela simples preferência entre uma escola filosófica ou outra. Até mesmo os autores citados têm sua obra questionada quanto a afinidades das teorias que conceberam com a filosofia da consciência, não superada.

Outra dificuldade foi a utilização de referenciais do senso comum, tanto jurídico como pessoal, em vista da sua separação dos procedimentos de análise exigidos pela pesquisa. A proposta do seu resgate na perspectiva de uma dupla ruptura epistemológica é tarefa complexa e que, por si só, demandaria a ocupação exclusiva do tema de pesquisa.

Por fim, as questões que a análise realizada pretendeu responder se acham apresentadas a seguir, em relação às quais se considera que os resultados obtidos foram satisfatórios, não apenas quanto à resposta em si, mas em relação às possibilidades abertas pelo estudo e pelas metodologias e técnicas de pesquisa aplicadas.

1) o STJ reexamina provas em recursos especiais ? Sim, embora não reconheça oficialmente essa prática.

2) qual o fundamento usado pelo STJ nessas decisões? A argumentação de que não reexamina mas valoração do ponto de vista legal o conteúdo dos fatos e das provas.

3) o conceito de valoração difere do reexame de provas ? Não, pois acaba redundando no mesmo processo de análise que haveria se ocorresse o reexame.

4) a instância recursal extraordinária adota a verdade formal? Sim, parcialmente, pois o STJ não aproveita todo o conteúdo da verdade das causas, mas seleciona o que lhe interesse. Além disso, estabelece 
a verdade na sua jurisprudência, quando a verdade formal dos autos contraria os seus precedentes.

5) qual o papel do livre convencimento nessa instância ? É secundário, pois os julgadores preferem não realizar um itinerário discursivo, optando por reafirmar os dogmas sumulados da jurisprudência do tribunal.

Com as ponderações realizadas sobre a análise efetuada neste capítulo, temos por encerrada a aplicação prática das teorias usadas na monografia, as quais estiveram voltadas ao entendimento da forma de utilização do Enunciado n. ${ }^{\circ} 5$ da Súmula do STJ.

Ao encerramento da presente monografia, cabe registro a obra "A Luneta Mágica”, de autoria de Joaquim Manuel de Macedo (1820 - 1882), médico, político e escritor fluminense, o qual retratou em seus romances mais famosos (O moço loiro, A moreninha, Os Dois Amores, etc.) as mazelas e a realidade sócio-cultural do Segundo Império.

O relato a seguir, na forma da transcrição parcial da síntese dessa obra, refletiria de maneira alegórica, a expectativa em relação ao campo do Direito e à superação das ideologias da sua prática:

[...] o protagonista da história, Simplício, é "míope física e moralmente", como ele mesmo diz. Ansioso por enxergar melhor, consegue por meio de um armênio uma luneta com a qual pode ver perfeitamente. É advertido de que não deverá fixá-la por mais de três minutos, após o que passará a ver além da aparência e apenas o Mal dentro das pessoas. Simplício não resiste a fixar a luneta por um tempo maior, e começa a ver mais do que gostaria, o que o leva quase à loucura. Acabe, sem intenção, quebrando a luneta, e pede ao armênio que lhe forneça outra. $\mathrm{O}$ homem concorda, mas adverte-o que desta vez veria apenas o Bem, se fixasse a luneta por mais de três minutos. Foi pior ainda e acabou por ser envolvido e enganado. Por fim, e após muitas confusões, ele acaba ganhando a luneta do bom senso, e assim encontra uma maneira de viver bem com a sociedade. [... $]^{177}$

\footnotetext{
${ }^{177}$ MACEDO, Joaquim Manuel de. A luneta mágica. Porto Alegre: L\&PM, 2001. p. 11-212.
} 
Conclui-se que Joaquim Macedo estabelece, na forma de uma fábula, um ensinamento moral: o míope é todo operador jurídico sem consciência de suas limitações ideológicas e discursivas; o armeiro é a sociedade, de onde provém as dinâmicas que alteram as práticas jurídicas e as ideologias; e a luneta, o conhecimento jurídico, sem fim, do qual provém a fonte de superação da falta de consciência de si mesmo e da realidade social.

\section{Conclusão}

Os resultados obtidos na realização da presente monografia podem ser definidos em relação a três aspectos desenvolvidos no trabalho de pesquisa: o conhecimento do objeto de estudo, as teorias utilizadas e os resultados encontrados.

Quanto ao objeto de estudo, o primeiro resultado foi reconhecer a importância da distinção de natureza das questões de direito, em contraposição às questões de fato, principal argumento utilizado pelo Superior Tribunal de Justiça - STJ como forma de justificar sua negativa em apreciar matérias fático-probatórias nos recursos especiais.

Foi visto que a doutrina a esse respeito, não é unânime e que o STJ adota a concepção dualista, pela qual o processo é mero complemento do direito material e que, por isso, não haveria como realizar o exame de questões do direito em sede de recursos.

E o aprofundamento da análise nesse ponto permitiu verificar que essa concepção do STJ tem a ver com os critérios similares à diferenciação das atribuições de instâncias judiciais no direito costumeiro (Commom Law), com o qual o STJ também compartilha a concepção de precedentes, como forma de controle de suas decisões.

Ainda em relação aos resultados quanto ao objeto, foi possível perceber que o princípio dispositivo ou da verdade formal não é aplicado da mesma forma que nas instâncias recursais ordinárias, pois o STJ não busca fundamentar nos autos as evidências de verdade para o convencimento dos julgadores, mas ora toma como 
referência sua própria norma (prequestionamento/precedentes), ora o conteúdo do próprio ato recorrido (acórdão).

O terceiro ponto diz respeito à distinção pelo STJ entre o reexame e a valoração da prova, onde essa argumentação justifica o exame de situações especiais, como no caso de comprovação de fatos por meio de certidões, o estabelecimento de valores de honorários profissionais e a quantificação de indenizações por danos.

Quanto às teorias utilizadas, foi possível descobrir a concepção de controle do livre convencimento motivado do julgador, por meio da criação de "standards", os quais seriam os critérios de avaliação do cumprimento do princípio processual a esse respeito.

Em função dessa descoberta, foi possível perceber que o STJ, como de modo geral a instância extraordinária (STF) possuem diversos mecanismos de controle (filtragem) no momento da cabimento dos seus recursos. No caso do STJ, foi possível examinar a questão do prequestionamento, da supressão de instância e da limitação do reexame de provas, mediante a edição de enunciado de súmula da sua jurisprudência.

Na parte do Capítulo 1, o resultado da aplicação dos conceitos da hermenêutica filosófica (desdogmatização, ruptura epistemológica, pré-noções, horizonte conceitual e círculo hermenêutico), na análise, foi relacionar o contexto histórico de surgimento dos recursos extraordinários e a concepção de tradição do STJ, ao fundamentar seus julgados na jurisprudência e no conceito dogmático da diferença entre fatos e direito.

Quanto à situação ideal de fala preconizada pela teoria da ação comunicativa, o seu estudo ofereceu um elemento de contraste à forma de realização da oralidade no processo, bem como, o conceito de agir estratégico servindo para identificar os interesses do STJ na realização das suas decisões.

O pano de fundo do trabalho, focado na importância da abordagem crítica da linguagem, como forma de aperfeiçoamento do campo jurídico, permitiu 
estabelecer não apenas os critérios de pesquisa, como também as expectativas de atuação judicial.

Daí a possibilidade de questionamento das práticas adotadas no cabimento dos recursos especiais, identificando o comportamento da instituição ao manter sua visão das normas jurídicas, com a preocupação em não modificar as justificativas dos seus julgados, saindo do campo do direito positivo para o campo do costume.

Ao encerramento da presente monografia, conclui-se que nos dias atuais o operador jurídico não pode prescindir de uma visão do direito, na qual se inclua a percepção das necessidades sociais e dos valores que cada pessoa tem em si e oferece no convívio com os demais, razão de ser da procura da compreensão, no presente trabalho, a respeito da importância da linguagem no mundo jurídico.

\section{"Quod non est in actis non est in mundo...": the diversity of interpretation of formal truth in the control of the review of evidence in special appeals by the Brazilian Superior Court of Justice}

\section{Abstract}

This study seeks to establish a relationship between the principle of formal truth and the foundations that uses the Brazilian Superior Court of Justice [Superior Tribunal de Justiça - STJ] to examine the pertinence of special appeals, with emphasis on which are known to be inapplicable to the statement $n^{\circ} 7$ of its precedent. The starting point was the identification of common elements between the analysis of the court a quo in the ordinary appellate court, and the one held by the STJ, as to the facts, circumstances and evidence in the judicial proceedings subject to a special appeal. The research methodology emphasized the epistemological basis of the so-called "linguistic overturn" of philosophy or "linguistic turn", which in the case of this study consists of the metaphysics overcoming, solipsism and the rigid division between subject and object of research, furthermore, in this study the ontological, hermeneutic and pragmatic "turns". The research techniques 
used were intended to present the results of preliminary research and the analysis of the jurisprudence of the STJ based on the notion of normative postulates and a presentation of the results more didactic as possible. As a result, it is expected to demonstrate that the control of special appeal by the STJ is analyzed based on the concept of Standards, from a textual analysis of the jurisprudence of the court judgments. Therefore, the analysis presented in this work contributes to the improvement of the discussion about the correlation of the principle of formal truth with the forms of control of free conviction that motivates the judge in the jurisprudence of the STJ.

Keywords: Civil procedure. Evidence. Review. Evaluation. Sentence. Special appeal. Case law. Precedent. Principles. Normative postulates. Oral. Formal truth. Free persuasion. Interpretation. Legal discourse. Ideology. Competent discourse. Speech acts. Communicative action. Paradox. Hermeneutic circle. Spiral hermeneutics. Linguistic turn. Semiotics. Common sense. Control and standards.

\section{Referências}

ARANHA, Maria Lúcia de Arruda. Filosofando: introdução à filosofia. 2. ed. rev. atual. São Paulo: Moderna, 1993.

ÁVILA, Humberto. Teoria dos princípios: da definição à aplicação dos princípios jurídicos. 8. ed. São Paulo: Malheiros, 2008. p. 122.

BARBOSA, Henry Bianor Chalu. Manual de direito processual civil básico. 2 ed. Curitiba: Juruá, 2006.

BARROSO, Carlos Eduardo Ferraz de Mattos. Processo civil: teoria geral do processo e processo de conhecimento. Vol. 11, 3 ed. rev. São Paulo: Saraiva, 2000.

BERTOLDI, Thiago M., RAUCH, Rafael. Superior Tribunal de Justiça: tribunal de sobreposição?. Disponível em: http://www.tex.pro.br/wwwroot/00/00 tribunal de sobreposição.php. Acesso em: 20 abr. 09.

BOURDIEU, Pierre. O Poder simbólico. Trad. de Fernando Tomaz. 11 ed. Rio de Janeiro: Bertrand Brasil, 2007. 
BRASIL. Constituição federal, código civil, código de processo civil. Organizador Yussef Said Cahali. 3. ed. rev.atual. e ampl. São Paulo: Revista dos Tribunais, 2001.

CAPEZ, Fernando. Curso de processo penal. 12. ed. rev. e atual. São Paulo: Saraiva, 2005.

CINTRA, Antônio Carlos de Araújo, GRINOVER, Ada Pellegrini, DINAMARCO, Cândido Rangel. Teoria geral do processo. 22. ed. São Paulo: Malheiros, 2006.

COSTA, Fábio Silva, Hermenêutica jurídica e direito contemporâneo: estudo acerca da operacionalidade do método interpretativo sistemático perante a redefinição paradigmática da ordem jurídica. São Paulo: Juarez de Oliveira, 2004.

COSTA, Henrique Araújo. Reexame de prova em recurso especial: a súmula 7 do STJ. Brasília: Thesaurus, 2008.

DINIZ, Maria Helena. As lacunas no direito. 8. ed. adaptada ao novo Código Civil (Lei n. ${ }^{\circ}$ 10.406, de 10 jan. 02). São Paulo: Saraiva, 2007.

FAZENDA, Ivani Catarina A. Interdisciplinariedade: um projeto em parceria. 5. ed. São Paulo: Edições Loyola, 2002.

FERREIRA, Luiz Alexandre Cruz et al. Hermenêutica, cidadania e direito. Campinas, SP: Millenium, 2005.

FUX, Luiz. Curso de direito processual civil. Rio de Janeiro: Forense, 2001.

GOMES, Luiz Flávio (Org). Direito processual penal. São Paulo: Editora Revista dos Tribunais: IELF, v. 6, 2005.

GRAU, Eros Roberto. Ensaio e discurso sobre a interpretação/aplicação do direito. 3. ed. São Paulo: Malheiros., 2005.

HABERMAS, Jürgen. Verdade e justificação: ensaios filosóficos. Tradução de Milton Camargo Mota. São Paulo: Loyola, 2004.

HEIDEGGER, Martin. Ser e verdade: a questão fundamental da filosofia; da essência da verdade. Tradução Emmanuel Carneiro Leão. Petrópolis: Vozes, 2007.

HOMMERDING, Adalberto Narciso. Fundamentos para uma compreensão hermenêutica do processo civil. Porto Alegre: Livraria do Advogado Editora, 2007. 
KIRKHAM, Richard L. Teorias da Verdade: uma introdução crítica. Tradução de Alessandro Zir. São Leopoldo: Unisinos, 2003.

KNIJNIK, Danilo. Os "standards" do convencimento judicial: paradigmas para o seu possível controle. Academia Brasileira de Direito Processual Civil. Disponível em: http://www.abdpc.org.br/artigos/artigo37.htm. Acesso em: 13 abr. 09.

LEAL, Rosemiro Pereira. Teoria geral do processo: primeiros estudos. 7.ed. rev.e atual. Rio de Janeiro: Forense, 2008.

MACEDO, Joaquim Manuel de. A luneta mágica. Porto Alegre: L\&PM, 2001.

MELLO, Marcos Bernardes de. Teoria do fato jurídico: plano da existência. 11. ed. São Paulo: Saraiva, 2001.

MENDONÇA, André Marinho. A concessão do efeito suspensivo ao recurso especial. Salvador: Faculdades Jorge Amado, 2007. p. 18. Disponível em: http:// bdjur.stj.gov.br. Acesso em: 15 out. 08 .

MICROSOFT CORPORATION. MICROSOFT OFFICE WORD 2007. Redmomd. Wa, () 2006. Editor de Textos.

MIRANDA, Gilson Delgado. Processo civil: recursos. 3. ed. São Paulo: Atlas, 2002.

MITIDIERO, Daniel Francisco. Introdução ao estudo do processo civil: primeiras linhas de um paradigma emergente. Porto Alegre: S. A. Fabris, 2004.

MORAES, Alexandre de. Direito constitucional. 14 ed. São Paulo: Atlas, 2003.

PORTANOVA, Rui. Princípios do processo civil. 7. ed. Porto Alegre: Livraria do Advogado Editora, 2008.

PRESIDÊNCIA DA REPÚBLICA. Constituição da República Federativa do Brasil. Disponível em: http://www.planalto.gov.br/ccivil_03/Constituicao/principal.htm. Acesso em: 02 out. 08 .

. Base da legislação federal. Disponível em: http://www.presidencia.gov.br/ legislacao/. Acesso em: 15 out. 08 .

REALE, Giovanni. História da filosofia antiga. Tradução de Marcelo Perine. São Paulo: Loyola, 1993. 
ROBLES, Gregorio. O direito como texto: quatro estudos de teoria comunicacional do direito. Tradução de Roberto Barbosa Alves. Barueri, SP: Manole, 2005.

ROCHA, Leonel Severo. Epistemologia jurídica e democracia. São Leopoldo: Ed. Unisinos, 1998.

SANTOS, Boaventura de Souza. Introdução a uma ciência pós-moderna. Rio de Janeiro: Graal, 1989.

SANTOS, Moacyr Amaral. Primeiras linhas de direito processual civil: $2^{\circ}$ volume. 24. ed. rev. e atual. Por Maria Beatriz Amaral Santos Köhnen. São Paulo: Saraiva, 2008.

SENADO FEDERAL. Constituição da República Federativa do Brasil, de 05 de outubro de 1988. [...] Disponível em: http://www.senado.gov.br/sf/legislacao. Acesso em: 15 out. 08.

action?
id $=64752$. Acesso em: 14 abr. 09.

SCHLICHTING, Arno Melo. Teoria geral do processo: concreta, objetiva, atual. 2. ed. Florianópolis: Momento Atual, 2004.

SILVA, Ovídio Baptista da. Teoria geral do processo civil. 3. ed. rev. e atual. São Paulo: Editora Revista dos Tribunais, 2002.

SOUZA, Bernardo Pimentel de. Introdução aos recursos cíveis e à ação rescisória. 3. ed. ampl. e atual. São Paulo: Saraiva, 2004.

SOUZA, Maria Cândida Gomes de. O espaço público judicial: a participação do judiciário na esfera democrática pela via da ação comunicativa. Orientadora: Giselle Cittadino. Rio de Janeiro: PUC, Departamento de Direito, 2005.

STRECK, Lênio Luiz. Hermenêutica jurídica $\mathbf{e}(\mathbf{m})$ crise: uma exploração hermenêutica da construção do direito. 7. ed. rev. atual. Porto Alegre: Livraria do Advogado Editora, 2007.

SUPERIOR TRIBUNAL DE JUSTIÇA. Disponível em: http://www.stj.jus.br/ SCON/regimento/. Acesso em: 15 out. 08. out. 08 .

. Disponível em: http://www.stj.jus.br/SCON/pesquisar.jsp. Acesso em: 15 
. 3a Turma. Ag Rg no Ag n. ${ }^{\text {1 }}$ 1.047.677/SP. Ementa: [...] Relator Ministro Massami Uyeda. Brasilia, DF, 03 mar. 09. DJe de 13 mar. 09.

SUPREMO TRIBUNAL FEDERAL. Disponível em: http://www.stf.jus.br/portal/ jurisprudencia/listarJurisprudencia.asp?. Acesso em: 24. mar. 09.

TUCCI, José Rogério Cruz e. Precedente judicial como fonte de direito. São Paulo: Revista dos Tribunais, 2004.

WATZLAWICK, Paul; BEAVIN, Janet Helmick; JACKSON, Don D. Pragmática da comunicação humana: um estudo dos padrões, patologias e paradoxos da interação. Tradução de Álvaro Cabral. 15. ed. São Paulo: Cultrix, 2005. 
Para publicar na revista Universitas/JUS, acesse 0 endereço eletrônico www.publicacoesacademicas.uniceub.br. Observe as normas de publicação, para facilitar e agilizar o trabalho de edição. 